\title{
Quinolone Complexes with Lanthanide Ions: An Insight into their Analytical Applications and Biological Activity
}

\author{
Ana-Mădălina Măciucă, Alexandra-Cristina Munteanu and Valentina Uivarosi *(i) \\ Department of General and Inorganic Chemistry, Faculty of Pharmacy, Carol Davila University of Medicine and \\ Pharmacy, 6 Traian Vuia St, Bucharest 020956, Romania; mada.maciuca@yahoo.com (A.-M.M.); \\ alexandra.ticea@umfcd.ro (A.-C.M.) \\ * Correspondence: valentina.uivarosi@umfcd.ro; Tel.: +4-021-318-0742; Fax: +4-021-318-0750
}

Academic Editor: Giuseppe Manfroni and Tommaso Felicetti

Received: 20 January 2020; Accepted: 12 March 2020; Published: 16 March 2020

check for updates

\begin{abstract}
Quinolones comprise a series of synthetic bactericidal agents with a broad spectrum of activity and good bioavailability. An important feature of these molecules is their capacity to bind metal ions in complexes with relevant biological and analytical applications. Interestingly, lanthanide ions possess extremely attractive properties that result from the behavior of the internal $4 \mathrm{f}$ electrons, behavior which is not lost upon ionization, nor after coordination. Subsequently, a more detailed discussion about metal complexes of quinolones with lanthanide ions in terms of chemical and biological properties is made. These complexes present a series of characteristics, such as narrow and highly structured emission bands; large gaps between absorption and emission wavelengths (Stokes shifts); and long excited-state lifetimes, which render them suitable for highly sensitive and selective analytical methods of quantitation. Moreover, quinolones have been widely prescribed in both human and animal treatments, which has led to an increase in their impact on the environment, and therefore to a growing interest in the development of new methods for their quantitative determination. Therefore, analytical applications for the quantitative determination of quinolones, lanthanide and miscellaneous ions and nucleic acids, along with other applications, are reviewed here.
\end{abstract}

Keywords: fluoroquinolones; lanthanides; metal complexes; biological activity; quantitative determination

\section{Introduction}

Quinolones comprise a series of synthetic bactericidal agents with a broad spectrum of activity and good bioavailability [1,2], characteristics that make them suitable candidates for treating infectious diseases with various localizations: cutaneous, urinary, respiratory, bone, gastrointestinal, etc. [3].

The starting point in the development of quinolones was the synthesis of nalidixic acid by G.Y. Lesher and coworkers in 1962, starting from 7-chloroquinoline (Figure 1a), a compound with antibacterial properties, a secondary product from the synthesis of chloroquine [4]. Nalidixic acid (Figure 1b) was proven to be active against certain Gram-negative pathogens, which led to the start of its clinical use in the treatment of urinary tract infections [5].

To date, numerous modifications have been brought to the nalidixic acid scaffold, which have resulted in a broader antibacterial spectrum, a different mode of binding to the plasmatic proteins and a longer half-time; significant changes have been obtained by the attachment of the fluorine atom in position 6 (fluoroquinolones) and a piperazine ring in position 7. Based on their chemical structures, these derivatives can be divided into four classes (Figure 1c): naphtyridine (nalidixic acid, enoxacin, gemifloxacin, tosufloxacin), cinnoline (cinoxacin), pyridopyrimidine (pipemidic acid, piromidic acid) and 4-quinolone (oxolinic acid, flumequine, norfloxacin, ciprofloxacin, ofloxacin, 
levofloxacin, sparfloxacin, etc.) [6]. Based on the antimicrobial spectrum and the pharmacological properties, four generations of quinolones are known. The improved properties of modern quinolones (4th generation) have rendered them suitable for treating more serious infections caused by particular pathogens (Gram-positive, resistant strains, anaerobe, etc.) with various localizations (respiratory, intra-abdominal, etc.) $[7,8]$.

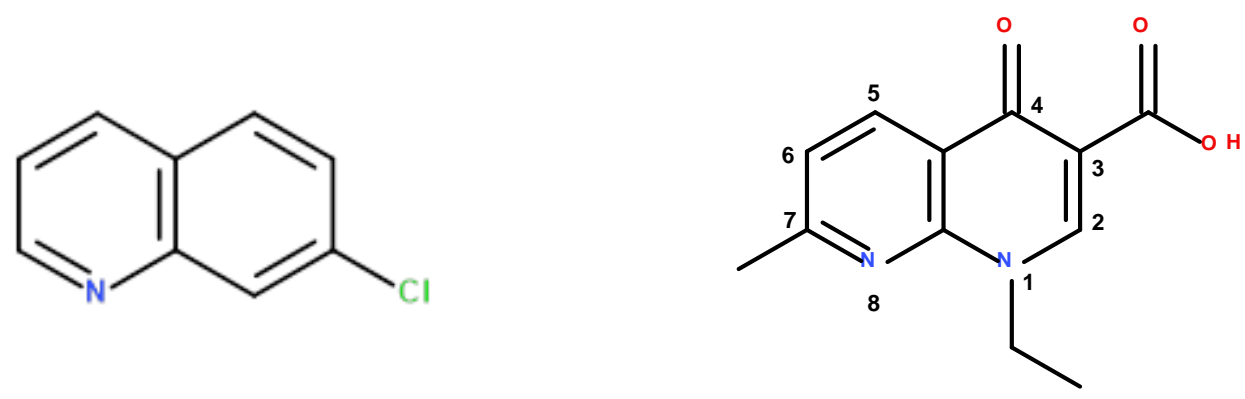

(a)

(b)<smiles>[R6][Y]1C([R5])=c2c(=O)c(C(=O)O)[Y]([R2])n([R1])c2=[Z]([R8])C1[R7]</smiles>

1. Naphthyridine (8-aza-4-quinolone): $X=C, Y=C, Z=N$;

2. Cinnoline (2-aza-4-quinolone): $X=N, Y=C, Z=C$;

3. Pyridopyrimidine (6,8-diaza-4-quinolone): $X=C, Y=N, Z=N$;

4. 4-Quinolone: $\mathrm{X}=\mathrm{C}, \mathrm{Y}=\mathrm{C}, \mathrm{Z}=\mathrm{C}$.

(c)

Figure 1. (a) 7-chloroquinoline; (b) nalidixic acid; (c) general structure and main classes of quinolones.

Quinolones possess a bactericidal mechanism of action which comes as a result of the inhibition of DNA transcription and replication in bacteria. In essence, in mycobacteria, and the majority of Gram-negative bacteria, quinolones act predominantly by disrupting the activity of topoisomerase II, also known as DNA-gyrase [9,10]; meanwhile in Gram-positive bacteria, topoisomerase IV is their primary target [11,12]. Although structurally related, the two enzymes play different roles in bacterial replication, a process known as binary fission. DNA-gyrase catalyzes the formation of negative supercoils in the circular, double-stranded bacterial DNA structure $[13,14]$. Topoisomerase IV is involved in the despiralization and decatenation of the double-stranded DNA molecule, preparing it for the transcription and replication processes, and separation of the DNA-daughter helices, facilitating their segregation into two daughter cells at the end of the replication process $[15,16]$.

Quinolones inhibit the activity of these two enzymes, not by direct binding, but through the formation of a quinolone-bacterial DNA-enzyme complex; this process disrupts DNA replication and consequently causes rapid cell death [17]. Magnesium ions are essential for the formation of the quinolone-DNA-enzyme complex [18]. In the proximity of the DNA binding site of the enzyme, $\mathrm{Mg}^{2+}$ is coordinated by two oxygen atoms from the quinolone molecules and four water molecules, in an octahedral arrangement (Figure 2) [19]. This process emphasizes the crucial importance of the 4-oxo (carbonyl) group for the antibacterial activity of quinolones. 


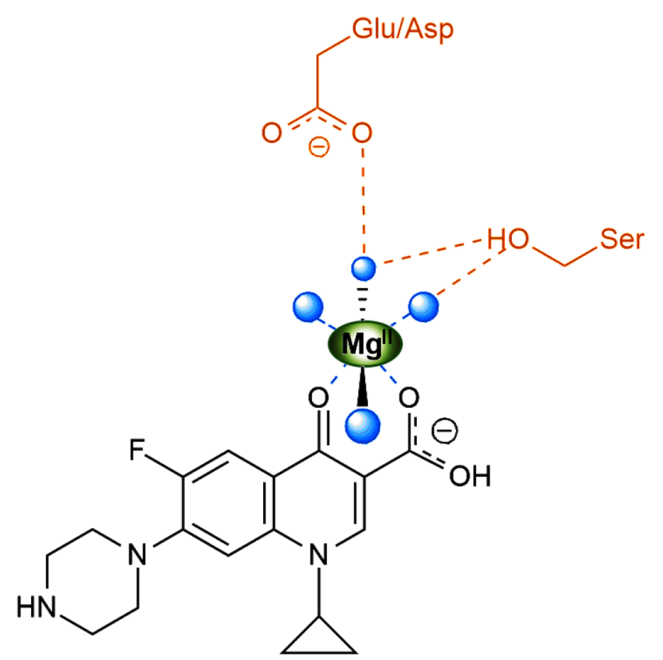

Figure 2. Coordination of $\mathrm{Mg}^{2+}$ at the binding site of ciprofloxacin to topoisomerase IV in the quinolone-DNA-enzyme complex; the four water molecules are represented through four blue bullets (adapted from [19], with permission https://pubs.acs.org/doi/10.1021/bi5000564; further permissions related to the material excerpted should be directed to the ACS).

Quinolone molecules, which possess a basic heterocyclic ring in position 7 (e.g., piperazinyl), display zwitterionic character. Between the $\mathrm{pH}$ values of 3 and 11, quinolones exist in the zwitterionic form, which is the most likely species to efficiently penetrate cell membranes; the completely protonated form $\left(\mathrm{QH}_{2}{ }^{+}\right)$exists in a proportion of $99.9 \%$ at the $\mathrm{pH}$ value of 1 , while at $\mathrm{pH}=7.4$ all species are present in quantifiable proportions [20].

Worthy of note is that these molecules possess a remarkable capacity to bind metal ions, correlated with the donor atoms in their structures (Figure 3). Depending on the working conditions ( $\mathrm{pH}$, nature of the metal ion, etc.), quinolones can act as bidentate ligands (coordinated to the metal ion via one oxygen atom from the carboxyl group and the oxygen atom from the 4-oxo moiety; via both oxygen atoms of the carboxyl moiety; or through the nitrogen atoms of the piperazine ring). Rarely, a unidentate coordination has been reported [21] (Figure 3).

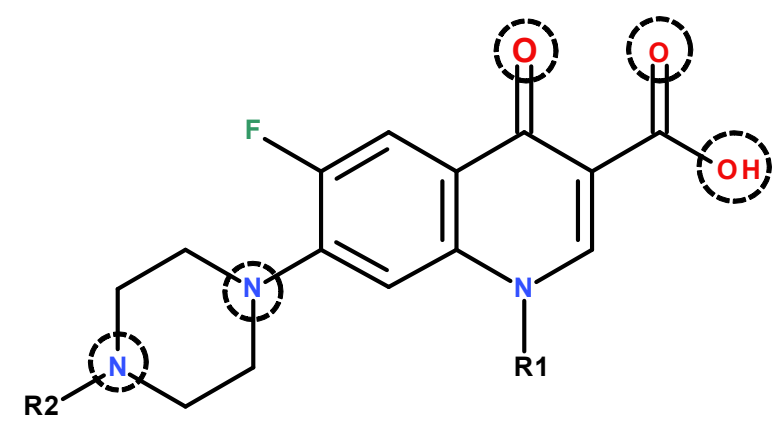

Figure 3. Donor atoms in the general structure of fluoroquinolones.

The ability of quinolones to form metal complexes has been explored in various ways. Numerous studies revealed a superior antimicrobial activity of the metal complexes compared to the free ligands, or even new biological activities (antifungal, antiparasitic or anticancer) [22-27]. Moreover, the quinolone-metal complexes are valuable in the battle against bacterial resistance, since they present higher lipophilicity due to the chelation effect [28] and offer a different mechanism of action, including their capacity to bind DNA. Metal complexation has found valuable analytical applications in the quantitative determination of both quinolones and metal ions. 


\section{Metal Complexes of Quinolones with Lanthanide Ions}

A relatively new direction in the field of complex combinations of quinolones is represented by chelates with lanthanide trivalent metal ions $\left(\mathrm{Ln}^{3+}\right)$. Lanthanides have become of interest to researchers after the observation that $\mathrm{Ca}^{2+}$ and $\mathrm{La}^{3+}$ are similar in terms of ionic radii, which led to the idea that $\mathrm{La}^{3+}$ can replace the former on different physiological binding sites, disrupting different physiological mechanisms [29]. Additionally, with the development of stable MRI contrast agents based on gadolinium (III) chelates [30-32] and the ability of $\mathrm{Tb}^{3+}$ and $\mathrm{Eu}^{3+}$ luminescent complexes to bind to the "drug site II" of serum albumin [33], the exploitation of chelating properties and luminescent complexes has begun.

The most important properties of lanthanides result from the behavior of the internal $4 \mathrm{f}$ electrons, behavior which is not lost upon ionization, nor after coordination. The strong electropositive character of lanthanides decreases with the drop in radius size, europium being the most reactive; likewise, the strong ionic trait of the compounds and the basic character of the hydroxides drop along the series, $\mathrm{Yb}(\mathrm{OH})_{3}$ and $\mathrm{Lu}(\mathrm{OH})_{3}$ being the least basic of all. Consequently, their aqua ions are the most predisposed to hydrolysis, phenomena that can be prevented by working in acidic conditions $[34,35]$. They predominantly form $\mathrm{Ln}^{3+}$ ions, but +4 and +2 oxidation states are also present in some cases $\left(\mathrm{Ce}^{4+}, \mathrm{Pr}^{4+}, \mathrm{Eu}^{2+}\right)$.

The correlation between hydrolysis constants and the drop in ion radius among the lanthanide series has been experimentally proven. At the end of the titration, with the rising in $\mathrm{pH}$ value, opalescence was observed due to the formation of $\mathrm{Ln}(\mathrm{OH})_{3}$ colloid solutions. A distribution of the species correlated to the $\mathrm{pH}$ values is represented in Figure 4 [36]. These data should be taken into account when choosing the $\mathrm{pH}$ value for the medium used for a complexation reaction.

On the matter of complex formation, lanthanides are classified as "class A" or "hard" acceptors, and therefore prefer "class A" or "hard" donor ligands (in the order $\mathrm{O}>\mathrm{N}>\mathrm{S}$ and $\mathrm{F}>\mathrm{Cl}$ ). In aqueous solutions, lanthanide ions attract water molecules, forming hydration shells; the number of water molecules varies: higher coordination numbers are characteristic for lighter lanthanides, $\left(\left[\operatorname{Ln}\left(\mathrm{H}_{2} \mathrm{O}\right)_{9}\right]^{3+}\right.$, $\mathrm{Ln}=\mathrm{La}-\mathrm{Eu})$ and lower numbers for the heavier lanthanides $\left(\left[\mathrm{Ln}\left(\mathrm{H}_{2} \mathrm{O}\right)_{8}\right]^{3+}, \mathrm{Ln}=\mathrm{Dy}-\mathrm{Lu}\right) . \mathrm{Eu}^{3+}$ and $\mathrm{Gd}^{3+}$ exist as mixed populations, displaying both hydration numbers. This decrease in hydration number can be explained by the rise in energy in the bond between the ion and each coordinated water molecule; the bond is so strong that only a few ligands can compete and form complexes in aqueous solutions, chelates being more stable. Coordination numbers vary from 6 to 12 in general; biologically relevant coordination numbers are 8 or 9 . Consequently, the complexes can have a variety of geometrical conformations. A coordination number of 10 requires ligands with "smaller bites," such as $\mathrm{NO}_{3}{ }^{-}$or $\mathrm{SO}_{4}{ }^{2-}$. Complexes with ligands with donor atoms other than oxygen are known, but they must be prepared in the absence of water [35].

Electronic transitions in the $4 \mathrm{f}$ orbitals of lanthanide ions give rise to characteristic absorption spectra. Only $\mathrm{Y}^{3+}, \mathrm{La}^{3+}$ and $\mathrm{Lu}^{3+}$ do not absorb in the UV or visible domain; all the other lanthanides have characteristic bands in this region, but the absorptivities have low values. The lanthanide ions with stronger fluorescence are $\mathrm{Sm}^{3+}, \mathrm{Eu}^{3+}, \mathrm{Tb}^{3+}$ and $\mathrm{Dy}^{3+}$, because the excitation energy level of these ions lies slightly lower than the excited levels of the ligands; thus they are able to readily accept the energy transfer [37]. A luminescent behavior suitable for detection and quantification can only be observed upon excitation by UV irradiation, X-rays, fast electrons, neutrons and certain chemical or mechanical means. It has been noted that certain molecules can enhance the luminescence of lanthanides upon complexation by indirect excitation via a suitable chromophore moiety in the complex [38].

When developing a synthesis method for quinolone-lanthanide complexes, one must take into account the zwitterionic nature of some quinolones and the $\mathrm{pH}$ value that is the most advantageous to the complexation process, and also correlate it to the $\mathrm{pH}$ value at which the lanthanide ion is stable, taking into account the hydrolysis tendencies it might have at a higher $\mathrm{pH}$. Table 1 summarizes various synthesis methods used for obtaining solid lanthanide-quinolone complexes. 
Table 1. Methods for the synthesis of quinolone complexes with lanthanide ions.

\begin{tabular}{|c|c|c|c|c|c|}
\hline Ligand & Complex & Material/Ligand:Ln Molar Ratio/pH Adjustment & Mixing Mode & Heating/Cooling & Ref \\
\hline Pipemidic acid (PPA) & $\begin{array}{l}{\left[\mathrm{M}(\mathrm{PPA})_{4} \mathrm{Cl}_{\mathrm{Cl}} \mathrm{Cl}_{2} \text { where } \mathrm{M}=\mathrm{La}^{3+}\right.} \\
{\left[\mathrm{M}(\mathrm{PPA})_{4}\right] \mathrm{Cl}_{3} \text { where } \mathrm{M}=\mathrm{Ce}^{3+}, \mathrm{Pr}^{3+}, \mathrm{Nd}^{3+}} \\
\mathrm{Sm}^{3+}, \mathrm{Tb}^{3+}, \mathrm{Dy}^{3+}, \mathrm{Y}^{3+}\end{array}$ & $\begin{array}{l}\text {-ligand salt dissolved in ethanol mixed with PPA } \\
\text { dissolved in acetic acid; } \\
-4: 1 ; \\
\text {-no pH adjustment. }\end{array}$ & & $\begin{array}{l}\text {-refluxed on water bath } 3-4 \mathrm{~h} \text {; } \\
\text {-cooling to room temperature. }\end{array}$ & [39] \\
\hline Nalidixic Acid (NAL) & $\begin{array}{l}{\left[\mathrm{Ln}(\mathrm{NAL})_{3}\right] \cdot \mathrm{nH}_{2} \mathrm{O}} \\
\mathrm{n}=5 \text { for } \mathrm{La}^{3+} \\
\mathrm{n}=6 \text { for } \mathrm{Ce}^{3+}, \mathrm{Pr}^{3+}, \mathrm{Sm}^{3+}\end{array}$ & $\begin{array}{l}\text {-aqueous solution of nalidixic salt with } \mathrm{Na}^{+}, \mathrm{pH}=8.5 ; \\
\text {-aqueous solution of } \mathrm{LnCl}_{3} \text {, } \\
-\mathrm{pH}=5 .\end{array}$ & $\begin{array}{l}\text {-nalidixate solution added slowly and under continuous } \\
\text { stirring. }\end{array}$ & $\begin{array}{l}\text {-heated until boiling, then kept in } \\
\text { refrigerator } 12 \mathrm{~h} \text {; } \\
\text {-deionized water added and repeated. }\end{array}$ & [40] \\
\hline \multirow[t]{4}{*}{ Ciprofloxacin (CPX) } & $\begin{array}{l}{\left[\mathrm{Ln}(\mathrm{CPX})_{2}\right] \mathrm{Cl} \cdot \mathrm{nH}_{2} \mathrm{O},} \\
\mathrm{n}=7-9 \mathrm{Ln}=\mathrm{Pr}^{3+}, \mathrm{Nd}^{3+}, \mathrm{Sm}^{3+}, \mathrm{Eu}^{3+}, \mathrm{Gd}^{3+}, \\
\mathrm{Tb}^{3+}, \mathrm{Dy}^{3+}, \mathrm{Ho}^{3+}, \mathrm{Er}^{3+}, \mathrm{Tm}^{3+}, \mathrm{Yb}^{3+} .\end{array}$ & $\begin{array}{l}\text {-ciprofloxacin } \mathrm{HCl} \text {, lanthanide oxides; } \\
\text {-2:1. }\end{array}$ & $\begin{array}{l}\text {-CPFX dissolved in } \mathrm{HCl} \text { solution and pyridine; } \\
\text {-Ln(III) oxides dissolved in conc. } \mathrm{HCl} \text {, heated to dryness } \\
\text { and dissolved in water; } \\
\text {-lanthanide solution dropped into CPFX, continuous } \\
\text { stirring ( } 2 \mathrm{~h}-5 \text { days). }\end{array}$ & & [41] \\
\hline & $\begin{array}{l}{\left[\mathrm{Ce}(\mathrm{CPX})_{2}\left(\mathrm{H}_{2} \mathrm{O}\right)_{4}\right] \mathrm{Cl} \cdot} \\
\left(\mathrm{H}_{2} \mathrm{O}\right)_{3.25} \cdot\left(\mathrm{C}_{2} \mathrm{H}_{5} \mathrm{OH}\right)_{0.25}\end{array}$ & $\begin{array}{l}\text {-ciprofloxacin } \mathrm{HCl}, \mathrm{CeCl}_{3} \cdot 7 \mathrm{H}_{2} \mathrm{O} \text {; } \\
\text {-2:1. }\end{array}$ & -lanthanide dissolved in water, added to CPFX solution. & $\begin{array}{l}\text {-stirring for } 7 \text { days at room temp; } \\
-20 \mathrm{~mL} \text { ethanol added, left standing at } \\
\text { room temp. }\end{array}$ & [41] \\
\hline & $\begin{array}{l}{\left[\mathrm{Eu}(\mathrm{CPXH})(\mathrm{CPX})\left(\mathrm{H}_{2} \mathrm{O}\right)_{4}\right] \mathrm{Cl}_{2} .} \\
4.55 \mathrm{H}_{2} \mathrm{O}\end{array}$ & $\begin{array}{l}\text {-- } \mathrm{EuCl}_{3} \cdot 6 \mathrm{H}_{2} \mathrm{O} \text {, ciprofloxacin } \mathrm{HCl} \text { hydrate, } 1,3 \text {-bis } \\
\text { (dimethylamino)- } \\
\text { 2 propranolol; } \\
-2: 1 \text {. }\end{array}$ & $\begin{array}{l}\text {-solvothermal method: substances in mixture of water } \\
\text { and ethanol } \\
\text {-placed in stainless steel autoclave. }\end{array}$ & $\begin{array}{l}\text {-heating at } 150^{\circ} \mathrm{C} \text { for } 48 \mathrm{~h} \text {, cooling; } \\
\text {-isothermal evaporation in the air. }\end{array}$ & [42] \\
\hline & {$\left[\mathrm{La}\left(\mathrm{H}_{2} \mathrm{O}\right)_{4}(\mathrm{CPX})_{2}\right] \mathrm{Cl}$} & $\begin{array}{l}\text { - } \mathrm{LaCl}_{3} \text {, ciprofloxacin; } \\
-2: 1 .\end{array}$ & -both substances suspended in methanol, stirred for $10 \mathrm{~h}$. & -reflux $8 \mathrm{~h}$. & [43] \\
\hline Enrofloxacin (EF) & $\begin{array}{l}{\left[\mathrm{La}_{2}\left(\mathrm{EF}_{6}\left(\mathrm{H}_{2} \mathrm{O}\right)_{2}\right] \cdot 14 \mathrm{H}_{2} \mathrm{O}\right.} \\
{\left[\mathrm{Sm}_{2}(\mathrm{EF})_{6}\left(\mathrm{H}_{2} \mathrm{O}\right)_{2}\right] \cdot 14 \mathrm{H}_{2} \mathrm{O}}\end{array}$ & $\begin{array}{l}-\mathrm{La}_{2} \mathrm{O}_{3}, \mathrm{Sm}_{2} \mathrm{O}_{3} \text { enrofloxacin, distilled water; } \\
-2: 1 .\end{array}$ & -components sealed in $25 \mathrm{ml}$ Teflon- lined stainless vessel. & $\begin{array}{l}\text {-heated at } 435 \mathrm{~K}, 3 \text { days; } \\
\text {-cooled at room temp. }\end{array}$ & [44] \\
\hline \multirow[t]{2}{*}{ Gatifloxacin (GFLX) } & $\begin{array}{l}{\left[\mathrm{Ln}(\mathrm{GFLX})_{3} \mathrm{Cl}_{3}\right] \cdot 2 \mathrm{H}_{2} \mathrm{O}_{1}} \\
\mathrm{Where} \mathrm{Ln}^{3} \mathrm{La}^{3+}, \mathrm{Nd}^{3+}, \mathrm{Eu}^{3+}, \mathrm{Tb}^{3+} .\end{array}$ & $\begin{array}{l}-\mathrm{GFLX}, \mathrm{LnCl}_{3} \cdot 6 \mathrm{H}_{2} \mathrm{O} \\
-3: 1\end{array}$ & $\begin{array}{l}\text {-HGA dissolved in acetone added dropwise into solution } \\
\text { of } \mathrm{LnCl}_{3} \cdot 6 \mathrm{H}_{2} \mathrm{O} \text { dissolved in ethanol. }\end{array}$ & -stirred and refluxed for $2 \mathrm{~h}$. & [45] \\
\hline & {$\left[\mathrm{Eu}(\mathrm{GFLX})_{3} \cdot 2 \mathrm{H}_{2} \mathrm{O}\right]$} & $\begin{array}{l}\text {-gatifloxacin, } \mathrm{EuCl}_{3} \cdot 6 \mathrm{H}_{2} \mathrm{O} \\
-3: 1 ; \\
-\mathrm{pH}=9 \text { with ammonium hydroxide. }\end{array}$ & $\begin{array}{l}\text {-gatifloxacin and } \mathrm{Eu}^{3+} \text { salt dissolved in deionized water, } \\
\text { while stirring; } \\
\text {-yellow solution obtained; }\end{array}$ & -stirring $2 \mathrm{~h}$ at room temp. & [46] \\
\hline \multirow[t]{3}{*}{ Gemifloxacin (GMFX) } & $\begin{array}{l}{\left[\mathrm{La}(\mathrm{GMFX})_{2}\left(\mathrm{H}_{2} \mathrm{O}\right)_{2}\right] \mathrm{Cl}_{3} \cdot 3 \mathrm{H}_{2} \mathrm{O}} \\
{\left[\mathrm{Ce}(\mathrm{GMFX})_{2}\left(\mathrm{H}_{2} \mathrm{O}\right)_{2}\right]\left(\mathrm{SO}_{4}\right)_{2} \cdot 2 \mathrm{H}_{2} \mathrm{O}}\end{array}$ & $\begin{array}{l}\text {-gemifloxacin, } \mathrm{LaCl}_{3} \cdot 7 \mathrm{H}_{2} \mathrm{O}, \mathrm{Ce}\left(\mathrm{SO}_{4}\right)_{2} \\
\text {-2:1. }\end{array}$ & $\begin{array}{l}\text {-substances dissolved in acetone, metal salt solution } \\
\text { added dropwise to the solution of gemifloxacin. }\end{array}$ & -stirring for $15 \mathrm{~h}$ at room temp. & [47] \\
\hline & $\begin{array}{l}{\left[\mathrm{La}(\mathrm{GMFX})(\mathrm{phen})\left(\mathrm{H}_{2} \mathrm{O}_{2}\right] \mathrm{Cl}_{3} \cdot 6 \mathrm{H}_{2} \mathrm{O}\right.} \\
{\left[\mathrm{Ce}(\mathrm{GMFX})(\text { phen })\left(\mathrm{H}_{2} \mathrm{O}\right)_{2}\right]} \\
\left(\mathrm{SO}_{4}\right)_{2} \cdot 3 \mathrm{H}_{2} \mathrm{O} \text {. }\end{array}$ & $\begin{array}{l}\text {-gemifloxacin, 1,10- phenanthroline, } \mathrm{LaCl}_{3} \cdot 7 \mathrm{H}_{2} \mathrm{O} \text {, } \\
\mathrm{Ce}\left(\mathrm{SO}_{4}\right)_{2} ; \\
\text {-GMFX: }\end{array}$ & $\begin{array}{l}\text {-mixing hot saturated solution on GMFX in acetone with } \\
\text { phen and metal salt. }\end{array}$ & -reflux for $3 \mathrm{~h}$. & [48] \\
\hline & $\begin{array}{l}{\left[\mathrm{Ce}(\mathrm{GMFX})(\mathrm{Gly})\left(\mathrm{H}_{2} \mathrm{O}\right)_{2}\right] \mathrm{Cl}_{2} .} \\
\mathrm{H}_{2} \mathrm{O}\end{array}$ & $\begin{array}{l}\text {-gemifloxacin, glycine, } \mathrm{CeCl}_{3} \cdot 7 \mathrm{H}_{2} \mathrm{O} \\
\text {-GMFX: metal: } \mathrm{Gly}=1: 1: 1\end{array}$ & $\begin{array}{l}\text {-metal salt dissolved in ethanol added dropwise to a } \\
\text { stirred solution of GMFX and Gly in ethanol; }\end{array}$ & $\begin{array}{l}\text {-reflux and stirring } 5-6 \mathrm{~h} \text { at } 100^{\circ} \mathrm{C} \text { in } \\
\text { water bath; }\end{array}$ & [49] \\
\hline Levofloxacin (LEVO) & {$\left[\mathrm{Ce}(\mathrm{LEVO})_{2}\left(\mathrm{H}_{2} \mathrm{O}\right)_{2}\right] \mathrm{SO}_{4} \cdot 5 \mathrm{H}_{2} \mathrm{O}$} & $\begin{array}{l}\text {-levofloxacin, } \mathrm{Ce}\left(\mathrm{SO}_{4}\right)_{2} \text {; } \\
\text {-2:1. }\end{array}$ & $\begin{array}{l}\text {-metal salt added to magnetically stirred solution of } \\
\text { LEVO and } \mathrm{NaOH} \text { in methanol and acetone. }\end{array}$ & -stirring at room temp for 1 day. & [50] \\
\hline Moxifloxacin (MOXI) & {$\left[\mathrm{Ce}(\mathrm{MOXI})_{2}\right]\left(\mathrm{SO}_{4}\right)_{2} \cdot 2 \mathrm{H}_{2} \mathrm{O}$} & $\begin{array}{l}\text {-moxifloxacin, }\left(\mathrm{NH}_{4}\right)_{4} \mathrm{Ce}\left(\mathrm{SO}_{4}\right)_{4} \cdot 2 \mathrm{H}_{2} \mathrm{O} \\
\text {-2:1. }\end{array}$ & $\begin{array}{l}\text {-ethanolic solution of metal salt added dropwise to a } \\
\text { stirred ethanolic solution of moxifloxacin. }\end{array}$ & $-24 \mathrm{~h}$ stirring at $50^{\circ} \mathrm{C}$ on water bath. & [51] \\
\hline Norfloxacin (NOR) & 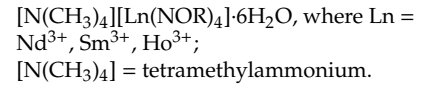 & $\begin{array}{l}\text {-norfloxacin, } \mathrm{Ln}\left(\mathrm{NO}_{3}\right)_{3} \cdot 6 \mathrm{H}_{2} \mathrm{O} \text {, imidazole; } \\
\text {-3:1. }\end{array}$ & $\begin{array}{l}\text {-norfloxacin, metallic salt and imidazole mixed with } \\
\text { distilled water and sealed in a } 25 \mathrm{ml} \text { Teflon-lined stainless } \\
\text { vessel. }\end{array}$ & $\begin{array}{l}\text {-heating at } 453 \mathrm{~K} \text { for } 3 \text { days; } \\
\text {-cooled slowly to room temp. }\end{array}$ & [52] \\
\hline
\end{tabular}


Table 1. Cont.

\begin{tabular}{|c|c|c|c|c|c|}
\hline Ligand & Complex & Material/Ligand:Ln Molar Ratio/pH Adjustment & Mixing Mode & Heating/Cooling & Ref \\
\hline & {$\left[\mathrm{La}(\mathrm{NOR})_{3}\right] \cdot 3 \mathrm{H}_{2} \mathrm{O},\left[\mathrm{Ce}(\mathrm{NOR})_{3}\right] \cdot 2 \mathrm{H}_{2} \mathrm{O}$} & $\begin{array}{l}\text {-norfloxacin, } \mathrm{CeCl}_{3} \cdot 7 \mathrm{H}_{2} \mathrm{O}, \mathrm{LaCl}_{3} \cdot 6 \mathrm{H}_{2} \mathrm{O} \\
\text {-3:1; } \\
\text {-basic pH with ammonia solution } 5 \% \text { v/v. }\end{array}$ & $\begin{array}{l}\text { a) } \\
\text {-NOR suspended in methanol mixed with metal salt } \\
\text { suspended in distilled water; } \\
\text {-solution basified by adding ammonia solution; } \\
\text { b) } \\
\text { complexes obtained as nanoparticles by the following } \\
\text { transformations: metal chlorides } \rightarrow \text { metal } \\
\text { carbonates } \rightarrow \text { nano-oxides } \rightarrow \text { metal chlorides } \rightarrow \text { above } \\
\text { described method; }\end{array}$ & $\begin{array}{l}\text { a) -reflux at } 80-90^{\circ} \mathrm{C} \text { for } 4-5 \mathrm{~h} \text {; } \\
\text { b) -reflux at } 80-90^{\circ} \mathrm{C} \text { for } 4-5 \mathrm{~h} .\end{array}$ & [53] \\
\hline & {$\left[\mathrm{La}(\mathrm{NOR})_{2} \mathrm{Cl}_{2}\right] \mathrm{Cl}$} & $-2: 1$ & -substances suspended in methanol. & -gently stirring for $10 \mathrm{~h}$ and reflux for $8 \mathrm{~h}$. & [54] \\
\hline \multirow[t]{2}{*}{ Ofloxacin (OFLO) } & $\begin{array}{l}{\left[\mathrm{Pr}(\mathrm{L}-\mathrm{OFLO})\left(\mathrm{NO}_{3}\right)_{2}\left(\mathrm{CH}_{3} \mathrm{OH}\right)\right]\left(\mathrm{NO}_{3}\right),} \\
{\left[\mathrm{NdOFLO}\left(\mathrm{NO}_{3}\right)_{2}\left(\mathrm{CH}_{3} \mathrm{OH}\right)\right]\left(\mathrm{NO}_{3}\right) \text {, where }} \\
\mathrm{L} \text {-OFLO = derivative obtained by } \\
\text { esterification of ofloxacin. }\end{array}$ & $\begin{array}{l}\text {-ofloxacin, } \mathrm{NaOH}, \operatorname{Pr}\left(\mathrm{NO}_{3}\right)_{3} \cdot 6 \mathrm{H}_{2} \mathrm{O}, \mathrm{Nd}\left(\mathrm{NO}_{3}\right)_{3} \cdot 6 \mathrm{H}_{2} \mathrm{O} \text {; } \\
\text {-ligand: } \mathrm{NaOH} \text { : metal = 0.25: } 0.25: 0.3 \text {. }\end{array}$ & $\begin{array}{l}\text {-ligand (L) obtained by esterification of ofloxacin with } \\
\text { ethanol, treatment with } \mathrm{N}_{2} \mathrm{H}_{4} \cdot \mathrm{H}_{2} \mathrm{O} \text { and refluxed with } \\
\text { 2-hydroxybenz-aldehyde; } \\
\text {-ligand and NaOH mixed in methanol; metal salt added. }\end{array}$ & $\begin{array}{l}\text {-refluxed and stirred for } 3 \mathrm{~h} \\
\text {-cooling to room temperature. }\end{array}$ & [55] \\
\hline & $\begin{array}{l}{\left[\operatorname{Pr}(\mathrm{L}-\mathrm{OFLO})_{2}\left(\mathrm{NO}_{3}\right)\right]\left(\mathrm{NO}_{3}\right)_{2} \text {, where L-OFLO }} \\
=\text { ofloxacin derivative. }\end{array}$ & $\begin{array}{l}\text {-ofloxacin, } \mathrm{NaOH}, \operatorname{Pr}\left(\mathrm{NO}_{3}\right)_{3} \cdot 6 \mathrm{H}_{2} \mathrm{O} \\
\text {-ligand: } \mathrm{NaOH} \text { metal = 0.25: } 0.25: 0.3 \text {. }\end{array}$ & $\begin{array}{l}\text {-ligand (L) obtained by esterification of ofloxacin with } \\
\text { ethanol, treatment with } \mathrm{N}_{2} \mathrm{H}_{4} \cdot \mathrm{H}_{2} \mathrm{O} \text { and refluxed with } \\
\text { 2-hydroxybenz-aldehyde; } \\
\text {-ligand and } \mathrm{NaOH} \text { mixed in methanol; metal salt added. }\end{array}$ & -stirring 3 hat room temp; & [56] \\
\hline Sparfloxacin (SPAR) & $\begin{array}{l}{\left[\mathrm{La}(\mathrm{SPAR})_{2} \mathrm{NO}_{3} \cdot \mathrm{H}_{2} \mathrm{O} \cdot 2 \mathrm{H}_{2} \mathrm{O}(1),\right.} \\
\left.\text { [La(SPAR)( } \mathrm{HL}) \mathrm{NO}_{3} \cdot \mathrm{H}_{2} \mathrm{O}\right] \cdot \mathrm{H}_{2} \mathrm{O}(2) \text {, where L } \\
=\text { DL-alanine. }\end{array}$ & $\begin{array}{l}\text {-sparfoxacin, } \mathrm{La}\left(\mathrm{NO}_{3}\right)_{3} \cdot 6 \mathrm{H}_{2} \mathrm{O}, \mathrm{DL} \text {-alanine; } \\
\text {-sparfloxacin: metal = 2; } 1 ; \\
\text {-sparfloxacin: DL-alanine: metal =1: } 1: 1 .\end{array}$ & $\begin{array}{l}\text {-metal salt dissolved in hot water } \\
\text {-ethanolic solution added to a hot ethanolic solution of } \\
\text { sparfloxacin and DL-alanin. }\end{array}$ & $\begin{array}{l}\text {-mixture stirred under reflux for } 2 \mathrm{~h} \text {; left } \\
\text { to cool. }\end{array}$ & [57] \\
\hline
\end{tabular}




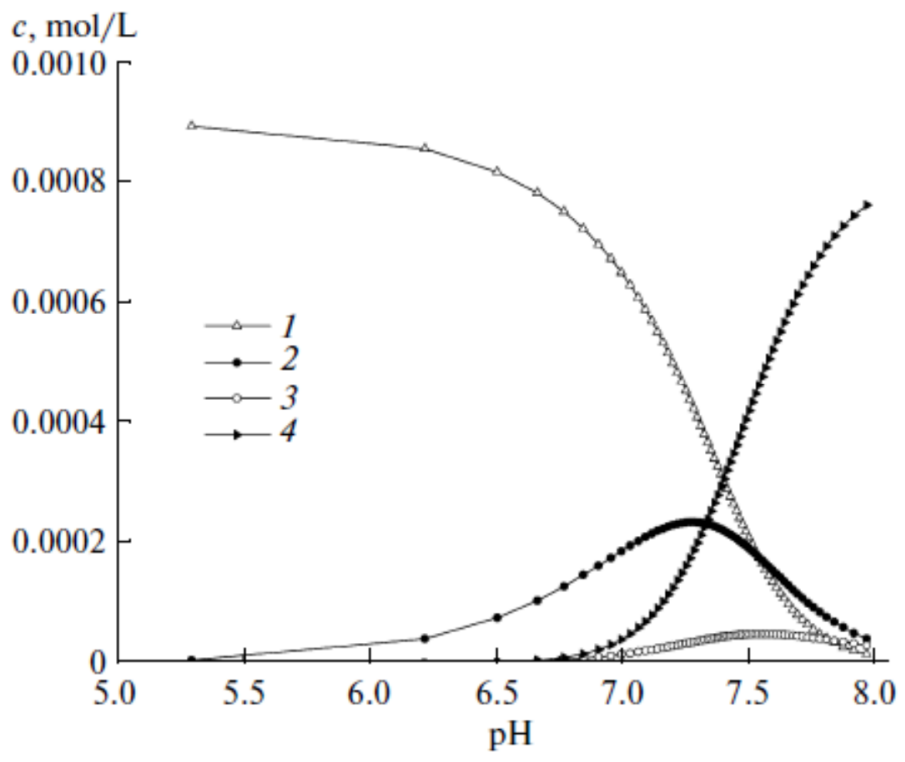

Figure 4. Equilibrium speciation distribution vs. $\mathrm{pH}$ for the $\mathrm{Lu}\left(\mathrm{NO}_{3}\right)_{3}$ system on the background of $0.1 \mathrm{M} \mathrm{KNO}_{3}:(1) \mathrm{Lu}^{3+},(2) \mathrm{Lu}(\mathrm{OH})^{2+}$, (3) $\mathrm{Lu}(\mathrm{OH})_{2}{ }^{+},(4) \mathrm{Lu}(\mathrm{OH})_{3}$-with permission from [36].

Analyzing the data presented in Table 1, some general remarks can be drawn as follows: the molar ratios used are 2:1 or in some cases 3:1 ligand to metal; several heteroleptic complexes have been reported, bearing as a second ligand 1,10-phenanthroline [48], DL-alanine [57] or glycine [49]. The $\mathrm{pH}$ value varies from 5 [40] to 9 [46]. The general scheme for synthesis is based on the following steps: the lanthanide salt and the quinolone are dissolved separately in different solvents (water, methanol, ethanol, acetone), and then the salt solution is added dropwise into the quinolone solution. The mixture is either kept under continuous stirring at room temperature for several hours (from $15 \mathrm{~h} \mathrm{[47]} \mathrm{to} 7$ days [41]) or refluxed for different periods of time (from $2 \mathrm{~h} \mathrm{[45]} \mathrm{to} 8 \mathrm{~h} \mathrm{[43]).} \mathrm{The} \mathrm{obtained}$ precipitate is removed from the reaction medium via filtration or centrifugation, washed and dried.

In the majority of these complexes, quinolone drugs behave as anionic, bidentate ligands coordinated to the metal ions via pyridone oxygen and carboxylate oxygen. In some complexes, quinolones are present in their zwitterionic form [45] or in both their anionic and zwitterionic forms [42]. The coordination mode via the carbonyl oxygen and hydroxyl oxygen of the carboxyl group [39] was also reported, while in a dinuclear complex with a nine-coordinated lanthanide ion, two anionic quinolone molecules acted as tridentate chelate and bridging ligands and two as bidentate chelate ligands [44].

\section{Biological Activity of Metal Complexes of Quinolones with Lanthanide Ions}

The biological activities of several metal complexes obtained in solid state have been assessed. Tables 2 and 3 comprise data regarding the biological activity evaluations and calf-thymus DNA (CT-DNA) and bovine serum albumin (BSA) binding studies published for quinolone complexes with lanthanide ions, respectively. 
Table 2. Biological activity of quinolone complexes with lanthanide ions.

\begin{tabular}{|c|c|c|c|c|}
\hline Ligand & Complex & Biological Activity Test & Results & Ref \\
\hline \multirow[t]{2}{*}{ Pipemidic acid (PPA) } & {$\left[\mathrm{La}(\mathrm{PPA})_{4} \mathrm{Cl}_{\mathrm{C}} \mathrm{Cl}_{2}\right.$} & -antibacterial activity on E. coli, S. aureus, P. aeruginosa similar to PPA; & $\begin{array}{l}\text {-antibacterial activity on S. pneumoniae much greater than PPA; } \\
\text {-NO activity on S. aureus }\end{array}$ & [39] \\
\hline & $\begin{array}{l}{\left[\mathrm{M}(\mathrm{PPA})_{4}\right] \mathrm{Cl}_{3} \text { where } \mathrm{M}=\mathrm{Ce}^{3+}, \mathrm{Pr}^{3+},} \\
\mathrm{Nd}^{3+}, \mathrm{Sm}^{3+}, \mathrm{Tb}^{3+}, \mathrm{Dy}^{3+}, \mathrm{Y}^{3+} .\end{array}$ & & $\begin{array}{l}\text {-Pr, Sm, Y complexes have similar activity to PPA against E. coli, S. aureus, } \\
\text { B. subtilis, S. pneumoniae; weaker activity on P. aeruginosa. }\end{array}$ & [39] \\
\hline \multirow[t]{2}{*}{ Ciprofloxacin (CPX) } & $\begin{array}{l}{\left[\mathrm{Er}(\mathrm{CPX})_{2}\left(\mathrm{H}_{2} \mathrm{O}\right)_{8}\right] \mathrm{Cl}} \\
{\left[\mathrm{Ce}(\mathrm{CPX})_{2}\left(\mathrm{H}_{2} \mathrm{O}\right)_{4}\right]} \\
\mathrm{Cl} \cdot\left(\mathrm{H}_{2} \mathrm{O}\right)_{3.25}\left(\mathrm{C}_{2} \mathrm{H}_{5} \mathrm{OH}\right)_{0.25}\end{array}$ & -MIC determined by broth tube dilution method; E. coli, P. aeruginosa, S. aureus; & $\begin{array}{l}\text {-for } \mathrm{Ce} \text {, the activity is } 2.5,2.5,1.25 \text { fold higher than } \mathrm{CPX} \text {; } \\
\text {-for } \mathrm{Er} \text {, the activity is } 2.5,1.25 \text { fold higher, resp. } 3.0 \text { fold lower than CPX. }\end{array}$ & [41] \\
\hline & {$\left[\mathrm{La}\left(\mathrm{H}_{2} \mathrm{O}\right)_{4}(\mathrm{CPX})_{2}\right] \mathrm{Cl}$} & -antibacterial activity against E. coli strains, through flat-filter paper method; & -the complex is less active than ciprofloxacin. & [43] \\
\hline Enrofloxacin (EF) & $\begin{array}{l}{\left[\mathrm{La}_{2}(\mathrm{EF})_{6}\left(\mathrm{H}_{2} \mathrm{O}\right)_{2}\right] \cdot 14 \mathrm{H}_{2} \mathrm{O}} \\
{\left[\mathrm{Sm}_{2}(\mathrm{EF})_{6}\left(\mathrm{H}_{2} \mathrm{O}\right)_{2}\right] \cdot 14 \mathrm{H}_{2} \mathrm{O}}\end{array}$ & $\begin{array}{l}\text {-antibacterial activity tested against B. subtilis, S. aureus, E. coli through the } \\
\text { diffusimetric method; }\end{array}$ & $\begin{array}{l}\text {-both complexes have bactericidal properties greater than the ligand; } \\
\text {-the } \mathrm{Sm}^{3+} \text { complex is more active than the } \mathrm{La}^{3+} \text { complex. }\end{array}$ & [44] \\
\hline \multirow[t]{3}{*}{ Gemifloxacin (GMFX) } & $\begin{array}{l}{\left[\mathrm{La}(\mathrm{GMFX})_{2}\left(\mathrm{H}_{2} \mathrm{O}\right)_{2}\right] \mathrm{Cl}_{3} \cdot 3 \mathrm{H}_{2} \mathrm{O}} \\
{\left[\mathrm{Ce}(\mathrm{GMFF})_{2}\left(\mathrm{H}_{2} \mathrm{O}\right)_{2}\right]} \\
\left(\mathrm{SO}_{4}\right)_{2} \cdot 2 \mathrm{H}_{2} \mathrm{O}\end{array}$ & $\begin{array}{l}\text {-antibacterial activity tested against S. aureus, B. subtilis, E. coli, P. aeruginosa, by } \\
\text { diffusimetric method; -antifungal activity tested against C. albicans, A. awamori, } \\
\text { Altenaria sp. by diffusimetric method; } \\
\text {-cytotoxic activity tested against human breast carcinoma cell line (MCF-7 } \\
\text { cells), human colon carcinoma cell line (HCT-116 cells), through crystal violet } \\
\text { colorimetric viability assay; }\end{array}$ & $\begin{array}{l}\text {-the activity of the } \mathrm{La}^{3+} \text { complex is comparable to gemifloxacin, but the } \\
\text { one of the } \mathrm{Ce}^{4+} \text { complex is slightly higher; } \\
\text {-only the } \mathrm{C}^{4+} \text { complex is active and only against } \mathrm{C} \text {. albicans; } \\
\text {-results were compared to the activity of doxorubicin; both complexes were } \\
\text { found to be active on both cell lines, but have } \mathrm{IC}_{50} \text { higher than doxorubicin; } \\
\mathrm{Ce}^{4+} \text { complex more active than } \mathrm{L}^{3+} \text { complex against the breast carcinoma } \\
\text { cell line; } \mathrm{La}^{3+} \text { complex more active than the } \mathrm{Ce}^{4+} \text { complex against the } \\
\text { colon carcinoma cell line. }\end{array}$ & [47] \\
\hline & $\begin{array}{l}{\left[\mathrm{La}(\mathrm{GMFX})(\mathrm{phen})\left(\mathrm{H}_{2} \mathrm{O}_{2}\right] \mathrm{Cl}_{3} \cdot 6 \mathrm{H}_{2} \mathrm{O}\right.} \\
{\left[\mathrm{Ce}(\mathrm{GMFX})(\mathrm{phen})\left(\mathrm{H}_{2} \mathrm{O}\right)_{2}\right]\left(\mathrm{SO}_{4}\right)_{2} \cdot 3 \mathrm{H}_{2} \mathrm{O}}\end{array}$ & $\begin{array}{l}\text {-antibacterial activity against S. aureus, B. subtilis, E. coli, P. aeruginosa, by } \\
\text { diffusimetric method; } \\
\text {-antifungal activity tested against C. albicans, A. azvamori, Alternaria sp. by } \\
\text { diffusimetric method; } \\
\text {-cytotoxic activity tested against human breast carcinoma cell line (MCF-7 cells) } \\
\text { and human colon carcinoma cell line (HCT-116 cells) by crystal violet staining } \\
\text { viability assay; doxorubicin used as positive control; }\end{array}$ & $\begin{array}{l}\text {-activity against } S \text {. aureus is comparable to GMFX; higher activities against } \\
\text { the others; } \\
\text {-comparable activity against C. albicans to GFX; no activity against other } \\
\text { fungi strains; } \\
\text {-complexes show cytotoxic activity, but lower than GMFX; phen also shows } \\
\text { cytotoxic activity, but higher than GMFX. }\end{array}$ & [48] \\
\hline & $\begin{array}{l}{\left[\mathrm{Ce}(\mathrm{GMFX})(\mathrm{Gly})\left(\mathrm{H}_{2} \mathrm{O}\right)_{2}\right]} \\
\mathrm{Cl}_{2} \cdot \mathrm{H}_{2} \mathrm{O}\end{array}$ & $\begin{array}{l}\text {-antibacterial activity tested against Xanthomonas campestris, Bacillus } \\
\text { megeterium, E. coli, Clavibacter michiganesis; } \\
\text {-antifungal activity tested against phytopathogenic fungi: Rhizoctonia solani, } \\
\text { Sclerotinia sclerotium, Aspergillus niger, Botrytis cinerea, } \text {, Renicillium digitatum; } \\
\text {-antioxidant activity tested through DPPH and ABTS methods; }\end{array}$ & $\begin{array}{l}\text {-GMFX and complex proved to be active against all strains, the weakest } \\
\text { activity being against } E \text {. coli and the highest against } C \text {. michiganensis; } \\
\text {-complex shows lower activity than GMFX against all strains; } \\
\text {-complex activity comparable to that of GMFX. }\end{array}$ & [49] \\
\hline Levofloxacin (LEVO) & $\begin{array}{l}{\left[\mathrm{Ce}(\mathrm{LEVO})_{2}\left(\mathrm{H}_{2} \mathrm{O}\right)_{2}\right] \mathrm{SO}_{4} .} \\
5 \mathrm{H}_{2} \mathrm{O}\end{array}$ & $\begin{array}{l}\text {-antibacterial activity tested against } \text { S. aureus, B. subtilis, B. otitidis, E. coli, } \\
\text { P. aeruginosa, K. oxytoca, by cup-diffusion technique; } \\
\text {-antifungal activity tested against A. flaurus, A. fumigatus, using the disc } \\
\text { diffusion sensitivity method; }\end{array}$ & $\begin{array}{l}\text {-the } \mathrm{Ce}^{4+} \text { proves to be more active on } B \text {. subtilis and } \\
\text { B. otitidis; } \\
\text {-no antifungal activity noted; }\end{array}$ & [50] \\
\hline Moxifloxacin (MOXI) & {$\left[\mathrm{Ce}(\mathrm{MOXI})_{2}\right]\left(\mathrm{SO}_{4}\right)_{2} \cdot 2 \mathrm{H}_{2} \mathrm{O}$} & $\begin{array}{l}\text {-antibacterial activity tested against S. aureus, B. subtilis, B. otitidis, E. coli, } \\
\text { P. aeruginosa, K. oxytoca by cup-diffusion method; }\end{array}$ & $\begin{array}{l}\text {-the complex shows similar activity against E.coli; } \\
\text {-no activity against P. aeruginossa and K. oxytoca; } \\
\text {-higher activity against B. subtilis, B. otitidis and S. aureus. }\end{array}$ & [51] \\
\hline Norfloxacin (NOR) & $\begin{array}{l}{\left[\mathrm{La}(\mathrm{NOR})_{3}\right] \cdot 3 \mathrm{H}_{2} \mathrm{O}} \\
{\left[\mathrm{Ce}(\mathrm{NOR})_{3}\right] \cdot 2 \mathrm{H}_{2} \mathrm{O}}\end{array}$ & $\begin{array}{l}\text {-antibacterial activities tested using modified Kirby-Bauer disk diffusion } \\
\text { method, against S. aureus, B. subtilis, E. coli, P. aeruginosa, C. albicans, A. flavus; } \\
\text { positive controls used: tetracycline and amphotericin; }\end{array}$ & $\begin{array}{l}\text {-complexes in nanoparticle form displayed greater activities than those in } \\
\text { normal- particle form, but lower than the positive controls; } \\
-\mathrm{La}^{3+} \text { nanocomplex is the most active. }\end{array}$ & [53] \\
\hline Ofloxacin (OFLO) & $\begin{array}{l}{\left[\mathrm{Pr}(\mathrm{L}-\mathrm{OFLO})\left(\mathrm{NO}_{3}\right)_{2}\left(\mathrm{CH}_{3} \mathrm{OH}\right)\right]\left(\mathrm{NO}_{3}\right)} \\
{\left[\mathrm{Nd}(\mathrm{L}-\mathrm{OFLO})\left(\mathrm{NO}_{3}\right)_{2}\left(\mathrm{CH} \mathrm{CH}_{3} \mathrm{OH}\right)\right]\left(\mathrm{NO}_{3}\right)} \\
\text { where } \mathrm{L}-\mathrm{OFLO}=\text { ofloxacin derivative. }\end{array}$ & $\begin{array}{l}\text {-antioxidant activity tested through hydroxyl radical scavenging activity } \\
\text { through the Fenton reaction; }\end{array}$ & -complexes show better activity than the ligand. & {$[55,58$} \\
\hline Sparfloxacin (SPAR) & $\begin{array}{l}{\left[\mathrm{La}(\mathrm{SPAR})_{2} \mathrm{NO}_{3} \cdot \mathrm{H}_{2} \mathrm{O}\right] \cdot 2 \mathrm{H}_{2} \mathrm{O}(1)} \\
{\left[\mathrm{La}(\mathrm{SPAR})(\mathrm{HL}) \mathrm{NO}_{3} \cdot \mathrm{H}_{2} \mathrm{O}\right]} \\
\mathrm{H}_{2} \mathrm{O}(2), \text { where } \mathrm{L}=\text { DL-alanin. }\end{array}$ & $\begin{array}{l}\text {-antibacterial activity tested against S. aureus, E. coli using modified } \\
\text { Kirby-Bauer disc diffusion method; tetracycline used as control; } \\
\text {-antifungal activity tested against A. flavus, C. albicans using modified } \\
\text { Kirby-Bauer disc diffusion method; amphotericin B used as control; }\end{array}$ & $\begin{array}{l}\text {-the complexes show the same activity as the free ligand, which is higher } \\
\text { than the control, against both bacteria; } \\
\text {-complexes and free ligand showed no antifungal activity. }\end{array}$ & [57] \\
\hline
\end{tabular}


Table 3. Calf-thymus (CT-DNA) and bovine serum albumin (BSA) binding tests for quinolone complexes with lanthanide ions.

\begin{tabular}{|c|c|c|c|c|}
\hline Ligand & Complex & Binding of Bovine Serum Albumin/CT-DNA & Results & Ref \\
\hline Ciprofloxacin (CPX) & {$\left[\mathrm{La}\left(\mathrm{H}_{2} \mathrm{O}\right)_{4}(\mathrm{CPX})_{2}\right] \mathrm{Cl}$} & $\begin{array}{l}\text {-CT-DNA binding properties investigated through UV-VIS spectroscopy and } \\
\text { fluorescence quenching methods; }\end{array}$ & $\begin{array}{l}\text {-binding ability of CPX and complex is the highest in basic medium and the lowest in } \\
\text { acidic medium. }\end{array}$ & [43] \\
\hline Enrofloxacin (CF) & $\begin{array}{l}{\left[\mathrm{La}_{2}(\mathrm{EF})_{6}\left(\mathrm{H}_{2} \mathrm{O}\right)_{2}\right] \cdot 14 \mathrm{H}_{2} \mathrm{O}} \\
{\left[\mathrm{Sm}_{2}(\mathrm{EF})_{6}\left(\mathrm{H}_{2} \mathrm{O}\right)_{2}\right] \cdot 14 \mathrm{H}_{2} \mathrm{O}}\end{array}$ & $\begin{array}{l}\text {-BSA binding properties investigated through UV-VIS spectroscopy and } \\
\text { fluorescence quenching methods; }\end{array}$ & $\begin{array}{l}\text {-both complexes have the ability to quench the fluorescence of } \mathrm{BSA}, \text { the } \mathrm{Sm}^{3+} \text { complex } \\
\text { more than the } \mathrm{La}^{+3} \text {; } \\
\text {-the mechanism is mainly a static one. }\end{array}$ & [44] \\
\hline Levofloxacin (LEVO) & {$\left[\mathrm{Ce}(\mathrm{LEVO})_{2}\left(\mathrm{H}_{2} \mathrm{O}\right)_{2}\right] \mathrm{SO}_{4} \cdot 5 \mathrm{H}_{2} \mathrm{O}$} & -CT-DNA degradation by testing electrophoretic mobility; & -the complex degrades the DNA completely compared to the metal salt. & [50] \\
\hline \multirow[t]{2}{*}{ Norfloxacin (NOR) } & $\begin{array}{l}{\left[\mathrm{N}\left(\mathrm{CH}_{3}\right)_{4}\right]\left[\mathrm{Ln}(\mathrm{NOR})_{4}\right]} \\
6 \mathrm{H}_{2} \mathrm{O}, \\
\mathrm{Ho}^{3+} ;\end{array}$ & $\begin{array}{l}\text {-CT-DNA binding investigated by UV absorbance of complex in the presence } \\
\text { of increasing amount of CT-DNA and by emission spectra of EB-DNA; }\end{array}$ & $\begin{array}{l}\text {-the complex binds to CT-DNA stronger than norfloxacin; } \\
\text {-interaction with BSA tested by measuring fluorescence quenching spectra; -complexes } \\
\text { have strong binding ability; } \\
\text {-the quenching process is a static one. }\end{array}$ & [52] \\
\hline & {$\left[\mathrm{La}(\mathrm{NOR})_{2} \mathrm{Cl}_{2}\right] \mathrm{Cl}$} & $\begin{array}{l}\text {-binding to CT-DNA, using UV-VIS absorption spectroscopy and } \\
\text { time-resolved fluorescence spectroscopy; }\end{array}$ & $\begin{array}{l}\text {-the complex shows moderate interaction with CT-DNA, by partial or } \\
\text { non-intercalative binding modes. }\end{array}$ & [54] \\
\hline \multirow[t]{2}{*}{ Ofloxacin (OFLO) } & $\begin{array}{l}{\left[\mathrm{Pr}(\mathrm{L}-\mathrm{OFLO})\left(\mathrm{NO}_{3}\right)_{2}\left(\mathrm{CH}_{3} \mathrm{OH}\right)\right]} \\
\left(\mathrm{NO}_{3}\right) \\
\left.\left[\mathrm{Nd}^{\mathrm{L}} \mathrm{L}-\mathrm{OFLO}\right)\left(\mathrm{NO}_{3}\right)_{2}\left(\mathrm{CH} \mathrm{CH}_{3} \mathrm{OH}\right)\right] \\
\left(\mathrm{NO}_{3}\right), \text { where L-OFLO }= \\
\text { ofloxacin derivative. }\end{array}$ & $\begin{array}{l}\text {-binding to BSA using fluorescence quenching and UV-VIS spectroscopy; } \\
\text {-DNA binding tested through viscosity measurement, electronic absorption } \\
\text { titration, ethidium bromide (EB) displacement experiments, CD spectra and } \\
\text { cyclic voltammetry experiments; } \\
\text {-DNA cleavage tested by electrophoresis; }\end{array}$ & $\begin{array}{l}\text {-tests confirm the intercalative binding mode of the complexes; interaction between } \\
\text { complexes and DNA is stronger than of the free ligand; } \\
\text {-the complexes show a concentration dependent activity through hydrolytic pathways. }\end{array}$ & {$[55,58]$} \\
\hline & $\begin{array}{l}{\left[\mathrm{Pr}(\mathrm{L}-\mathrm{OFLO})_{2}\left(\mathrm{NO}_{3}\right)\right]\left(\mathrm{NO}_{3}\right)_{2}} \\
\text { where } \mathrm{L}-\mathrm{OFLO}=\text { ligand } \\
\text { obtained from ofloxacin }\end{array}$ & $\begin{array}{l}\text {-BSA binding tested through fluorescence quenching experiments; } \\
\text {-CT-DNA binding tested through UV spectroscopy, UV titration experiments, } \\
\text { competitive studies with EB, iodide quenching; } \\
\text {-DNA cleavage tested through electrophoresis }\end{array}$ & $\begin{array}{l}\text {-the complex binds to BSA with high affinity which induces a conformational change } \\
\text { of BSA; } \\
\text {-the complex binds to DNA more strongly than the free ligand; } \\
\text {-the complex shows such activity. }\end{array}$ & [56] \\
\hline
\end{tabular}


It was observed that the complexes have improved water solubility in comparison with the quinolone parent molecule. Thereby, the complexation may improve both the hydrophilic and lipophilic properties of quinolone, and give better bioavailability and antibacterial activity [41]. Liposolubility is an important factor for the antimicrobial activity. Upon complexation, the polarity of the metal ion is reduced due to the overlap with ligand orbitals and partial sharing of the positive charge of the metal ion with the donor groups. The increased liposolubility of the ligand upon metal chelation may contribute to its facile transport into the bacterial cell; once it has entered the cell as a metal complex, the ligand blocks the metal binding sites of crucial bacterial enzymes [50].

When taking into account the chemical structures of the metal complexes, the following five principal factors greatly influence their antimicrobial activities: (1) the chelate effect-bidentate ligands show higher antimicrobial efficiency towards complexes with monodentate ligands; (2) the nature of the ligand/ligands; (3) the total charge of the complex; the antimicrobial activity varies in the following order-cationic > neutral > anionic complex; (4) the nature of the counter ion for ionic complexes; (5) the nuclearity of a metal center in complex with a dinuclear center is more active than that of a mononuclear one [21].

Briefly, lanthanide complexes of quinolones have been tested in regard to their antibacterial, antifungal, antitumoral and/or antioxidant properties; in addition, in some cases, their ability to bind to calf-thymus DNA (CT-DNA) and bovine serum albumin (BSA) has also been quantified. The antibacterial activity was tested against Escherichia coli, Staphylococcus aureus, Pseudomonas aeruginosa, Streptococcus pneumoniae and Bacillus subtilis; meanwhile, the antifungal activity was tested against Candida albicans and Aspergillus awamori. As a general remark, the complexes showed no antifungal activity, except for the complex of $\mathrm{Ce}^{4+}$ with gemifloxacin [48]. The antibacterial activity of the complexes varies greatly, from being lower than the ligand [43], to being the same for some strains [39,47,48,51,57] and to being higher than the ligand [39,41,44,48,50,51]. Regarding the CT-DNA and BSA binding experiments, the complexes proved to have higher affinity than the ligand both for the former $[52,55,58]$ and the latter $[44,56]$.

\section{Analytical Applications of Metal Complexes of Quinolones with Lanthanide Ions}

\subsection{Quantitative Determination of Quinolones}

Due to quinolones being widely prescribed in both human and animal treatments, their concentration in nature has reached a critical level [59]. This led to an increasing interest in the development of new methods for their quantitative determination. The challenge is that these methods need not only address the determination of quinolones in pure state, pharmaceutical formulations and biological fluids, but also in water, soil and animal products, such as milk and meat.

Fluoroquinolones and their metabolites enter the environment after human or veterinary use, as a result of their excretion through urine or stool; after the human excreta enters sewage-treatment plants, most compounds reach the sewage sludges; some by-products are used to fertilize soils and others remain in water effluents. Alternate ways for fluoroquinolones to enter the water circuit are through treatment of the aquaculture and/or direct discharge. Although studies show that fluoroquinolones suffer photolysis [60] in the surface layers of water under direct exposure to UV radiation, adsorption or biodegradation, the phenomenon raises concerns about the environmental impact and the promotion of resistant strains [61]. Fluoroquinolones eliminated by animals end up in manure which is later used as fertilizer in agricultural soils (Figure 5). A discussion about how this process affects the soil has been made elsewhere [62]. Fluoroquinolones from domestic or hospital waste or from the manufacturing process are not considered relevant, as they are subjected to regulatory control. In some cases, however, the concentrations of antibiotics in hospital effluents are of the same order of magnitude as the minimum inhibitory concentrations [63]. 


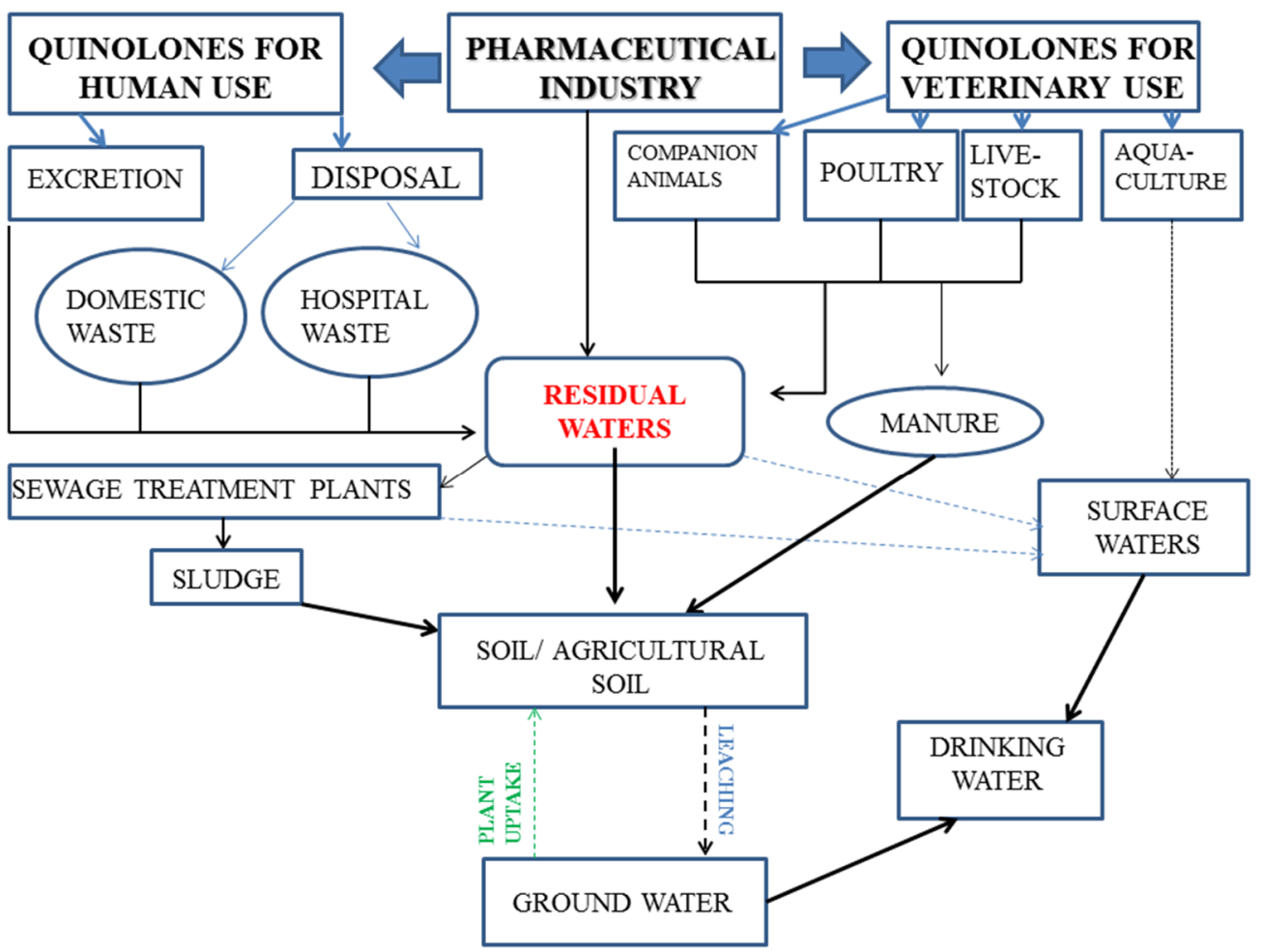

Figure 5. Main routes of contaminating the environment with quinolones for human or veterinary use (adapted after $[59,63]$ ).

This has challenged researchers to develop new methods for the quantitative determination of quinolones that are sensitive to concentrations of nanograms $/ \mathrm{mL}$ [64] or micrograms $/ \mathrm{kg}$ [65], and to adapt them in order to use complex matrices (e.g., food or soil) as probes.

Numerous methods have been reported for the determination of quinolones; namely, HPLC [66,67], capillary electrophoresis [68,69], MS spectrometry [70], voltammetry [71,72], polarography [73], titrimetry [74] and spectrophotometry $[75,76]$. Among them, spectrofluorometry and luminescence methods have been reported to be the most attractive to scientists, as they are highly sensitive and simple methods that require inexpensive equipment, and are suitable for the analysis of compounds in either pure state, pharmaceutical formulations or biological fluids. Various methods have been developed; e.g., native drug fluorescence measurements or fluorescence measurements after the formation of charge transfer complexes, chemometric methods, lanthanide sensitized fluorescence and chemiluminescent methods. Methods for the measurement of native fluorescence of quinolones in different systems or enhanced fluorescence due to complex formation with different metals have been reviewed by Singh et al. [77].

Due to their large conjugation systems and rigid structures, most quinolones absorb in the UV region and possess intrinsic fluorescence. Their UV spectra generally display two main peaks: one around $250 \mathrm{~nm}$ (strong) and one around $300 \mathrm{~nm}$ (weak). The excitation wavelength is set at around 300 $\mathrm{nm}$ in order to avoid the direct excitation of the lanthanide cation. It can be observed that upon addition of the lanthanide cation, the fluorescence intensity of the fluoroquinolone decreases as the specific bands of the $\mathrm{Ln}^{3+}$ cation appear. The energy absorbed by the quinolone molecule at its characteristic excitation wavelength is transferred to a triple state of the molecule and then intramolecularly transferred to a resonance level of the lanthanide ion, which finally emits luminescence at its particular emission wavelength. The efficiency of the transfer depends on the match of the ligand and lanthanide energy levels [78].

Lanthanide cations possess intrinsic photoluminescent properties. However, their poor ability to absorb light energy and their fast non-radiative deactivation by solvent molecules prevent the generation 
of luminescence by direct excitation. This issue can be resolved via luminescence sensitization or antenna effect, meaning chelation with appropriate organic ligands that enhance the spectroscopic properties of the lanthanide ions [79]. These chelates present a series of spectroscopic properties which render them suitable for analysis: narrow and highly structured emission bands; large gaps between absorption and emission wavelengths (Stokes shifts); and long excited-state lifetimes [80,81]. Once the chelate is formed, an intramolecular energy transfer takes place from the excited state of the ligand to the emitting level of the cation.

Trivalent lanthanide cations $\left(\mathrm{Ln}^{3+}\right)$ are prevalent in chelates. $\mathrm{Ln}^{3+}$ possess a $4 \mathrm{f}^{\mathrm{n}}$ subshell, wherein

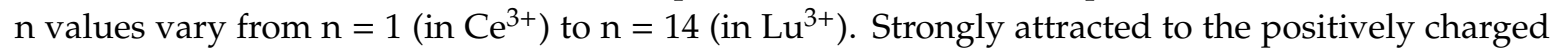
nucleus and shielded from any external forces by the filled $5 \mathrm{~s}$ and $5 \mathrm{p}$ orbitals, the $4 \mathrm{f}$ electrons are not susceptible to photoexcitation. This phenomenon is reflected in the low extinction coefficients, sharp absorption and emission bands and long-lived luminescence. Upon coordination, the energy is absorbed by the ligand and transferred to the cation, which ultimately leads to emission. Thus, the excitation and emission wavelengths are characteristic of the ligand and the lanthanide ion, respectively. The energy-transfer process can be intramolecular or intermolecular [82].

The intramolecular process requires the formation of a chelate. The light energy absorbed by the ligand in its ground state $\left(\mathrm{S}_{0}\right)$ leads to the generation of an excited single state $\left(\mathrm{S}_{1}\right)$. Energy is then transferred through a process called intersystem crossing to an excited triple state $\left(\mathrm{T}_{1}\right)$, from which the energy can be transferred to the $4 \mathrm{f}$ electrons of the lanthanide ion. Thus, these electrons become excited, and upon returning to their ground state, emit radiation at characteristic wavelengths. The energy transfer depends on the ligand structure and the energy level of its triple state, which has to be higher than but close to the resonance level of the lanthanide ion. The mechanism is shown for $\mathrm{Tb}^{3+}$ in Figure 6 [81]. Moreover, there are other non-radiative and radiative mechanisms that can compete with this particular energy transfer and luminescence, such as fluorescence, phosphorescence and non-radiative relaxation. In order to minimize the effects of these processes, synergistic agents and micellar solutions are normally used. $\mathrm{Tb}^{3+}$ and $\mathrm{Eu}^{3+}$ have been preponderantly used for analytical purposes, due to their longer decay times and intense emission bands at $545 \mathrm{~nm}$ and $612 \mathrm{~nm}$, respectively [80].

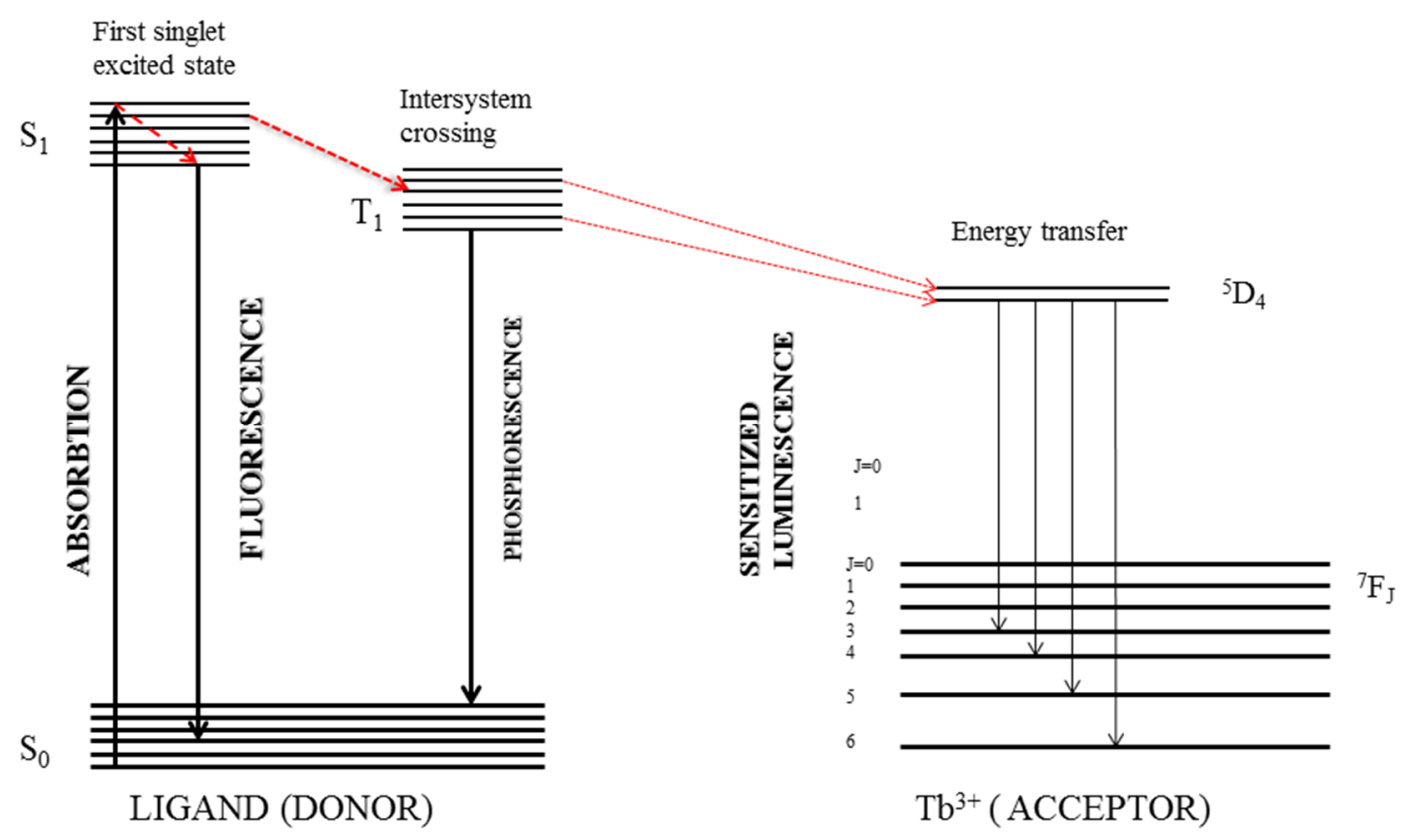

Figure 6. Intramolecular energy transfer for $\mathrm{Tb}^{3+}$, with permission from [81].

The intermolecular process implies no chelate formation; the energy is transferred from the triple state of an organic compound, such as an aromatic aldehyde or ketone, to the $4 \mathrm{f}$ electrons of the 
lanthanide ion. The process is diffusion controlled, induced through collisional quenching and takes place after the encounter between the donor and the acceptor [82].

These processes present a series of characteristics, such as large Stokes shifts and narrow emission bands, which render them suitable for analytical purposes, allow for low sample blanks and minimize overlapping. All of the above-mentioned characteristics result in high sensitivity and selectivity. Moreover, long-lived excited states enable the implementation of time-resolution detection techniques [83].

The luminescent properties of a lanthanide-quinolone complex are structure-related. Upon complexation, the conjugate plane increases and the structure becomes more rigid. A higher stability of the complex results in a smaller energy loss and a more efficient energy transfer, which increases the luminous efficiency of $\mathrm{Ln}^{3+}$. Small variations in quinolone rings and substituent groups greatly influence these phenomena. For instance, the ether group (ofloxacin, gatifloxacin) or thioether group (rufloxacin) in the $R_{1}$ position (see Figure $1 c$ ) results in $p-\pi$ conjugation with the quinolone ring, creating an electron pushing effect which reduces the electron density in the carbonyl and carboxyl groups, diminishing the coordination ability of the quinolone. This results in weak energy transfer and low luminescence intensity. In the case of sparfloxacin, the $-\mathrm{NH}_{2}$ group in the $\mathrm{R}_{5}$ (see Figure 1c) position forms an intramolecular hydrogen bond with the carbonyl group, causing a non-planar twist of the pyridine ring, which in turn reduces the $\pi$-bond's degrees of freedom. This results in quenched luminescence of the quinolone and its complexes [78].

In order to minimize the ligand deactivating processes and to optimize chelate formation, different methods have been used: use of synergistic agents; changes in $\mathrm{pH}$, surfactants, columinescence or heavy atoms or use of a solid phase [81].

Lanthanide cations are known to have high coordination numbers in the range of 6-12. In cases where only two quinolone molecules are bound to the central ion, other ligands, such as 1,4,7,10-tetraazacyclododecane-1,4,7-triacetic acid (DO3A) [84] or tri-n-octylphosphine oxide (TOPO), have been used. This strategy proved to be necessary in order to avoid filling the coordination sphere with solvent molecules, represented in most cases by water, which will result in non-radiative deactivations. These ligands create a sheath around the complex, assuring desolvation [85], or can fill in the coordination sphere of the lanthanide ion [86]. Moreover, the removal of oxygen atoms from the coordination sphere enhances luminescence [87-89].

The zwitterionic nature of fluoroquinolones renders their structures and abilities to form metal complexes to be greatly affected by $\mathrm{pH}$. Thus, the increase of the $\mathrm{pH}$ values leads to an increased rate of complex formation, but also favors the rate of hydrolysis of the lanthanide cation. The most frequently used $\mathrm{pH}$ values lie in the range of 5-9 (see Table 4 and citations therein). The systems using chemiluminescence imply the use of acidic $\mathrm{pH}$ for the redox reaction.

There is a drastic increase in fluorescence in microheterogeneous organized media rather than homogenous solutions [90,91]; micellar solutions obtained with anionic surfactants have the role of bringing the reactants together by trapping the energy donor inside the micelle and binding the lanthanide ion to its surface [85], enhancing the stability of the complexes and shielding them from quenchers [91]. The same effect can be obtained by using coordination polymer nanoparticles (CPNPs) [92], coordination polymer nanosheets (CPNSs) [93] or nanoparticles (NPs) [84,94-99]. 
Table 4. Methods for quantitative determination of quinolones based on complexation with lanthanides.

\begin{tabular}{|c|c|c|c|c|c|}
\hline Quinolone & Method (System, Optimum pH, Optimum Buffer Conditions) & $\lambda_{\text {exitation }} / \lambda_{\text {emission }}$ & $\begin{array}{l}\text { Limit of Detection/Limit ofQuantification } \\
\text { (LOD/LOQ) }\end{array}$ & Matrix & Ref \\
\hline \multirow[t]{4}{*}{ Balofloxacin (BLFX) } & $\begin{array}{l}\text { BLFX-Eu }{ }^{3+} \text {-SDBS system; } \\
\text { pH = 7.5-tris HCl buffer; }\end{array}$ & $335 \mathrm{~nm} / 618 \mathrm{~nm}$ & $\mathrm{LOD}=5 \mathrm{nM}$ & Serum and urine samples & [111] \\
\hline & $\begin{array}{l}\text { BLFX-Eu }{ }^{3+} \text {-SDBS system; } \\
\text { pH = 7.5-tris HCl buffer; }\end{array}$ & $335 \mathrm{~nm} / 618 \mathrm{~nm}$ & $\mathrm{LOD}=1.3 \mathrm{nM}$ & Bile Acid & [112] \\
\hline & $\mathrm{BLFX}-\mathrm{Eu}^{3+}-\mathrm{KBrO}_{3}-\mathrm{Na}_{2} \mathrm{~S}_{2} \mathrm{O}_{4}$-SDBS chemiluminescence system & $\begin{array}{l}\text { CL excitation/593 nm, } \\
617 \mathrm{~nm}\end{array}$ & $\mathrm{LOD}=0.069 \mathrm{nM}$ & $\begin{array}{l}\text { Pharma-ceutical formulations and biological } \\
\text { fluids }\end{array}$ & [113] \\
\hline & BLFX-Eu ${ }^{3+}-Y^{3+}-$ SDBS system & $330 \mathrm{~nm} / 618 \mathrm{~nm}$ & $\mathrm{LOD}=0.83 \mathrm{nM}$ & $\begin{array}{l}\text { Pharma-ceutical formulations, human serum, } \\
\text { urine }\end{array}$ & [114] \\
\hline \multirow[t]{15}{*}{ Ciprofloxacin (CPX) } & $\begin{array}{c}\text { CPX-Tb+3-TOPO system } \\
\mathrm{pH}=\text { 5.5-acetate buffer; micellar solution of } \mathrm{CPCl}\end{array}$ & $333 \mathrm{~nm} / 546 \mathrm{~nm}$ & $\mathrm{LOD}=1.2 \mathrm{nM}$ & Serum samples & [85] \\
\hline & $\begin{array}{c}\text { CPX-Tb }{ }^{3+} \text {-SLS system; } \\
\text { pH = 6- acetic acid- sodium acetate buffer; }\end{array}$ & $300-325 \mathrm{~nm} / 549 \mathrm{~nm}$ & $\mathrm{LOD}=30-150 \mathrm{~mol} / \mathrm{kg}$ & Chicken and trout muscle sample & [115] \\
\hline & $\begin{array}{l}\text { CPX-Ad/Tb }{ }^{3+} \text { CPNP nanoparticles; } \\
\text { pH = 7.5-HEPES buffer; }\end{array}$ & $288 \mathrm{~nm} / 545 \mathrm{~nm}$ & $\mathrm{LOD}=60 \mathrm{nM}$ & Aqueous solution, urine, tablets & [92] \\
\hline & $\begin{array}{l}\text { CPX-Tb }{ }^{3+} \text {-DO3A NPs; } \\
\text { pH = 7.4-HEPES buffer; }\end{array}$ & $278 \mathrm{~nm} / 542 \mathrm{~nm}$ & $\mathrm{LOD}=9 \mathrm{nM}$ & Urine & [84] \\
\hline & $\begin{array}{c}\mathrm{CPX}-\mathrm{Tb}^{3+} \text {-TOPO system; } \\
\mathrm{pH}=\text { 6-piperazine andimidazole buffer; }\end{array}$ & $320 \mathrm{~nm} / 545 \mathrm{~nm}$ & $\mathrm{LOD}=100 \mathrm{nM}$ & LC eluent & [116] \\
\hline & $\begin{array}{c}\mathrm{CPX}-\mathrm{Tb}^{3+} \text { system; } \\
\text { pH }=5.7 \text {-potassium hydrogen phthalate buffer; } \\
\text { (Additionally applied for: enrofloxacin and flumequine) }\end{array}$ & $337 \mathrm{~nm} / 545 \mathrm{~nm}$ & $\mathrm{LOD}=9.6 \mathrm{nM}$ & Water samples & [117] \\
\hline & $\begin{array}{l}\mathrm{CPX}-\mathrm{Tb}^{3+}-\mathrm{SDS}-\mathrm{Na}_{2} \mathrm{SO}_{3} \text { system; } \\
\text { pH = 6.5-acetate buffer; }\end{array}$ & $271 \mathrm{~nm} / 545 \mathrm{~nm} ;$ & $\mathrm{LOD}=1810.7 \mathrm{nM}$ & Serum samples & [108] \\
\hline & $\begin{array}{c}\mathrm{CPX}-\mathrm{Tb}^{3+}-\mathrm{CTAB} \text { system; } \\
\mathrm{pH}=7.3 \text {-Tris buffer; } \\
\text { in the presence of tetracycline. }\end{array}$ & $284 \mathrm{~nm} / 545 \mathrm{~nm}$ & $\mathrm{LOD}=27162 \mathrm{nM}$ & Serum and urine samples & [118] \\
\hline & $\begin{array}{c}\text { CPX-Th } 3^{3+}-\text { SDS system; } \\
\mathrm{pH}=5.7 \text {-sodium acetate buffer; }\end{array}$ & $278 \mathrm{~nm} / 545 \mathrm{~nm}$. & $\begin{array}{l}\mathrm{LOD}=422.5 \mathrm{nM} ; \\
\mathrm{LOQ}=1508.9 \mathrm{nM}\end{array}$ & Milk samples & [86] \\
\hline & 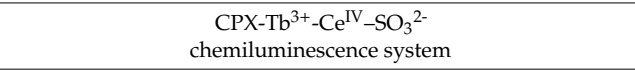 & $\begin{array}{l}\text { CL excitation/ } 490 \mathrm{~nm}, 545 \mathrm{~nm}, \\
585 \mathrm{~nm} 620 \mathrm{~nm}\end{array}$ & $\mathrm{LOD}=0.31 \mathrm{nM}$ & Capsules, human serum and urine samples & [119] \\
\hline & $\begin{array}{c}\mathrm{CPX}-\left[\mathrm{Tb}(\mathrm{bpy})_{2}\right]^{3+}-\mathrm{K}_{2} \mathrm{~S}_{2} \mathrm{O}_{8} \\
\mathrm{pH}=\text { 5.5- acetic acid- sodium acetate buffer }\end{array}$ & $\begin{array}{c}\text { ECL excitation/ } 490 \mathrm{~nm}, 545 \\
\mathrm{~nm}, \\
585 \mathrm{~nm} 620 \mathrm{~nm} \\
\end{array}$ & $\mathrm{LOD}=1.4 \mathrm{nM}$ & Pharma-ceutical tablets & [120] \\
\hline & $\begin{array}{l}\text { CPX- } \mathrm{Tb}^{3+} \text {-calf thymus DNA; } \\
\mathrm{pH}=5.5-\text { acetic acid }- \text { sodium acetate buffer }\end{array}$ & $272 \mathrm{~nm} / 545 \mathrm{~nm}$ & $\mathrm{LOD}=37.9 \mathrm{nM}$ & eye-ear pharma-ceutical dosage forms & [121] \\
\hline & $\begin{array}{c}\text { CPX-Eu }{ }^{3+}+\text { phen system; } \\
\text { pH = 9-acetate-ammonia buffer; micellar solution of DDBS. }\end{array}$ & $330 \mathrm{~nm} / 615 \mathrm{~nm}$ & $\mathrm{LOD}=230 \mathrm{nM}$ & Pharma-ceutical tablets, blood serum & [91] \\
\hline & $\begin{array}{l}\text { CPX-Eu } 3+\text {-GMP NPs; } \\
\text { pH = 7.4-HEPES buffer; }\end{array}$ & $276 \mathrm{~nm} / 615 \mathrm{~nm}$ & $\mathrm{LOD}=780 \mathrm{nM}$ & Pharma-ceutical tablets & [94] \\
\hline & $\begin{array}{l}\text { CPX-Eu }{ }^{3+} \text { system in acetonitrile; } \\
\mathrm{pH}=6 \text {-borate buffer; }\end{array}$ & $365 \mathrm{~nm} / 615 \mathrm{~nm}$ & $\mathrm{LOD}=15 \mathrm{nM} ; \mathrm{LOQ}=45 \mathrm{nM}$ & Pharma-ceutical tablets, serum & {$[122]$} \\
\hline
\end{tabular}


Table 4. Cont.

\begin{tabular}{|c|c|c|c|c|c|}
\hline Quinolone & Method (System, Optimum pH, Optimum Buffer Conditions) & $\lambda_{\text {exitation }} / \lambda_{\text {emission }}$ & $\begin{array}{l}\begin{array}{c}\text { Limit of Detection/Limit ofQuantification } \\
\text { (LOD/LOQ) }\end{array} \\
\end{array}$ & Matrix & Ref \\
\hline & $\begin{array}{l}\text { CPX-Eu } 3+\text {-Ag NPs; } \\
\mathrm{pH}=9.4 \text {-tris-HCl buffer }\end{array}$ & $373 \mathrm{~nm} / 614 \mathrm{~nm}$ & $\mathrm{LOD}=0.057 \mathrm{nM}$ & Pharma-ceutical tablets, serum & [123] \\
\hline & $\begin{array}{l}\mathrm{CPX}-\mathrm{Eu}^{3+} \text { functionalized } \mathrm{Ga}(\mathrm{OH})(\mathrm{btec}) \cdot 0.5 \mathrm{H}_{2} \mathrm{O} \text {, where } \mathrm{H}_{4} \mathrm{btec}= \\
1,2,4,5 \text {-benzenetetra-carboxylic acid }\end{array}$ & $370 \mathrm{~nm} / 614 \mathrm{~nm}$ & $\mathrm{LOD}=7243 \mathrm{nM}$ & Urine samples & [124] \\
\hline $\begin{array}{c}\text { Danofloxacin } \\
\text { (DAN) }\end{array}$ & $\begin{array}{l}\text { DAN-Tb }{ }^{3+} \text {-SDS-Na }{ }_{2} \mathrm{SO}_{3} \text { system; } \\
\text { pH }=6.5 \text {-acetate buffer; }\end{array}$ & $271 \mathrm{~nm} / 545 \mathrm{~nm}$; & LOD $=1810.7 \mathrm{nM}$ & Serum samples & [108] \\
\hline \multirow[t]{5}{*}{ Enoxacin (ENX) } & $\begin{array}{c}\mathrm{ENX}-\mathrm{Dy}^{3+}-\mathrm{Ce}^{4+}-\mathrm{S}_{2} \mathrm{O}_{3}{ }^{2-}-\mathrm{H}_{2} \mathrm{SO}_{4} \text { system; } \\
\text { (Additionally applied for: lomefloxacin, offloxacin, norfloxacin, gatifloxacin) }\end{array}$ & $\begin{array}{l}\text { CL excitation/482 nm, } \\
578 \mathrm{~nm}\end{array}$ & $\mathrm{LOD}=624.3 \mathrm{nM}$ & Biological fluids & [109] \\
\hline & ENX- $\mathrm{Dy}^{3+}-\mathrm{MnO}_{4}^{-}-\mathrm{S}_{2} \mathrm{O}_{3}^{2-}-\mathrm{HNO}_{3}$ system; & $\begin{array}{l}\text { CL excitation / } 482 \mathrm{~nm} \\
578 \mathrm{~nm}\end{array}$ & $\mathrm{LOD}=686.8 \mathrm{nM}$ & Biological fluids & {$[125]$} \\
\hline & $\begin{array}{l}\text { ENX- } \mathrm{Tb}^{3+}-\mathrm{Na}_{2} \mathrm{SO}_{3} \text { system; } \\
\quad \mathrm{pH}=7\end{array}$ & $\begin{array}{c}\text { ECL excitation } / 490 \mathrm{~nm}, \\
545 \mathrm{~nm}, \\
585 \mathrm{~nm}, \\
620 \mathrm{~nm} .\end{array}$ & $\mathrm{LOD}=0.054 \mathrm{nM}$ & Dosage forms, urine samples. & [106] \\
\hline & $\begin{array}{l}\mathrm{ENX}-\mathrm{Tb}^{3+}-\mathrm{KMnO}_{4}-\mathrm{Na}_{2} \mathrm{SO}_{3} \\
\text { (Additionally applied for ofloxacin) }\end{array}$ & $\begin{array}{c}\text { CL excitation } / 490 \mathrm{~nm}, \\
545 \mathrm{~nm}, \\
585 \mathrm{~nm}, \\
620 \mathrm{~nm} .\end{array}$ & $\mathrm{LOD}=0.24 \mathrm{nM}$ & Dosage forms, urine sample & [126] \\
\hline & $\begin{array}{l}\text { ENX-Tb } 3^{3+} \text { - acetylacetone NPs } \\
\mathrm{pH}=7.2 \text {, phosphate buffer }\end{array}$ & $\begin{array}{l}345 \mathrm{~nm} / 559 \mathrm{~nm} \\
\text { (FRET method) }\end{array}$ & $\mathrm{LOD}=30 \mathrm{nM}$ & Dosage forms, urine sample & {$[127]$} \\
\hline \multirow[t]{7}{*}{ Enrofloxacin (EF) } & $\begin{array}{l}\text { EF-Eu }{ }^{3+} \text {-phen system; } \\
\text { pH = 9- acetate-ammonia buffer; micellar solution of DDBS. }\end{array}$ & $330 \mathrm{~nm} / 615 \mathrm{~nm}$ & $\mathrm{LOD}=230 \mathrm{nM}$ & Blood sample & [91] \\
\hline & $\begin{array}{l}\text { EF-Eu }{ }^{3+} \text {-optical sensor } \\
\mathrm{pH}=7.8\end{array}$ & $395 \mathrm{~nm} / 617 \mathrm{~nm}$ & $\mathrm{LOD}=75 \mathrm{nM}$ & Pharma-ceutical tablets and serum samples & [128] \\
\hline & $\begin{array}{c}\text { EF-Eu }^{3+} \text {-polymer nanofilament-based } \\
\text { optical sensor } \\
\mathrm{pH}=7.5, \text { HEPES buffer }\end{array}$ & $340 \mathrm{~nm} / 612 \mathrm{~nm}$ & $\mathrm{LOD}=580 \mathrm{nM}$ & Water-rich media & [129] \\
\hline & $\begin{array}{c}\text { EF-Tb }{ }^{3+}-\text { SLS system; } \\
\text { pH }=\text { 6-acetic acid-sodium acetate buffer; }\end{array}$ & $\begin{array}{l}300 \mathrm{~nm}- \\
325 \mathrm{~nm} / 549 \mathrm{~nm}\end{array}$ & $\mathrm{LOD}=5.56 \mathrm{nM}$ & Chicken and trout muscle sample & {$[115]$} \\
\hline & $\begin{array}{c}\text { EF-Th } 3^{+}-\mathrm{Ag} \mathrm{NPs} \\
\mathrm{pH}=6 \text {, Tris-HCl buffer }\end{array}$ & $327 \mathrm{~nm} / 545 \mathrm{~nm}$ & $\begin{aligned} \text { LOD } & =58.4 \mathrm{nM} \\
\mathrm{LOQ} & =191.9 \mathrm{nM}\end{aligned}$ & Milk samples & [130] \\
\hline & 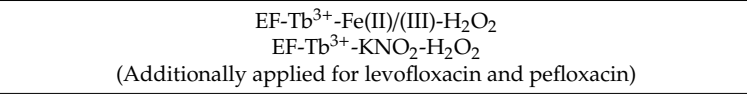 & $\begin{array}{l}\text { CL excitation/440 nm } \\
515 \mathrm{~nm}\end{array}$ & $\begin{array}{l}\mathrm{LOD}=120 \mathrm{nM} \\
\mathrm{LOD}=240 \mathrm{nM}\end{array}$ & Pharma-ceutical forms and urine samples & [131] \\
\hline & $\begin{array}{c}\text { EF-Th }{ }^{3+}-\text { calf thymus DNA } \\
\mathrm{pH}=6.5 \text {-hexamethylenetetramine buffer }\end{array}$ & $324 \mathrm{~nm} / 546 \mathrm{~nm}$ & $\mathrm{LOD}=6.95 \mathrm{nM}$ & Beef serum & [132] \\
\hline \multirow[t]{3}{*}{ Fleroxacin (FLX) } & $\begin{array}{c}\mathrm{FLX}^{\mathrm{LDy}}{ }^{3+}-\mathrm{MnO}_{4}{ }^{-}-\mathrm{S}_{2} \mathrm{O}_{3}{ }^{2-}-\mathrm{H}_{6} \mathrm{P}_{4} \mathrm{O}_{13} \text { system; } \\
\text { (Additionally applied for pefloxacin and pipemidic acid) }\end{array}$ & $\begin{array}{l}\text { CL excitation/482 nm, } \\
578 \mathrm{~nm}\end{array}$ & $\mathrm{LOD}=0.812 \mathrm{nM}$ & Foods, biological samples & [104] \\
\hline & $\mathrm{FLX}-\mathrm{Dy}^{3+}-\mathrm{KMnO}_{4}-\mathrm{Na}_{2} \mathrm{~S}_{2} \mathrm{O}_{3}-\mathrm{H}_{6} \mathrm{P}_{4} \mathrm{O}_{13}$ & $\begin{array}{l}\text { CL excitation/482 nm, } \\
578 \mathrm{~nm}\end{array}$ & $\mathrm{LOD}=0.3 \mathrm{nM}$ & Injections and urine sample & [133] \\
\hline & $\begin{array}{l}\mathrm{FLX}-\mathrm{Eu}^{3+}-\left[(\mathrm{Me})_{4} \mathrm{~N}_{2}\left[\mathrm{~Pb}_{6} \mathrm{~K}_{6}(\mathrm{~m}-\mathrm{BDC})_{9}(\mathrm{OH})_{2}\right] \cdot \mathrm{H}_{2} \mathrm{O} \text {, where 1,3- }-\mathrm{H}_{2} \mathrm{BDC}=\right. \\
\text {-benzenedicarboxylic acid })\end{array}$ & $377 \mathrm{~nm} / 612 \mathrm{~nm}$ & $\mathrm{LOD}=118.8 \mathrm{nM}$ & Human serum and urine & [134] \\
\hline
\end{tabular}


Table 4. Cont.

\begin{tabular}{|c|c|c|c|c|c|}
\hline Quinolone & Method (System, Optimum pH, Optimum Buffer Conditions) & $\lambda_{\text {exitation }} / \lambda_{\text {emission }}$ & $\begin{array}{l}\text { Limit of Detection/Limit ofQuantification } \\
\text { (LOD/LOQ) }\end{array}$ & Matrix & Ref \\
\hline & $\begin{array}{l}\text { FLX-Tb }{ }^{3+} \text { photochemical fluorimetric system } \\
\text { pH }=5.7 \text {, acetate buffer }\end{array}$ & $320 \mathrm{~nm} / 545 \mathrm{~nm}$ & $\mathrm{LOD}=12 \mathrm{nM}$ & Human urine samples & [135] \\
\hline \multirow[t]{4}{*}{ Flumequine (FLU) } & $\begin{array}{l}\text { FLU-Tb }{ }^{3+} \mathrm{Ce}^{4+}-\mathrm{Na}_{2} \mathrm{SO}_{3}-\mathrm{H}_{2} \mathrm{SO}_{4} \\
\text { system; }\end{array}$ & Excitation by redox reaction/- & $\begin{array}{l}\mathrm{LOD}=382.7 \mathrm{nM} ; \\
\mathrm{LOQ}=1148.1 \mathrm{nM} ;\end{array}$ & Waste water samples & [105] \\
\hline & $\begin{array}{l}\text { FLU-Tb } 3^{+}-\text {SDS micelles system; } \\
\text { pH = 7.6-Tris buffer; }\end{array}$ & $340 \mathrm{~nm} / 545 \mathrm{~nm}$ & $\mathrm{LOD}=210.5 \mathrm{nM}$ & Chicken muscle and liver, whole milk. & [136] \\
\hline & $\begin{array}{l}\text { FLU-Tb } \mathrm{Tb}^{3+}-1,10-\mathrm{phenanthroline} \mathrm{in} \\
\text { micellar SDS solutions } \\
\mathrm{pH}=7.5 \text {-acetate-ammonia buffer }\end{array}$ & $330 \mathrm{~nm} / 545 \mathrm{~nm}$ & $\mathrm{LOD}=4.9 \mathrm{nM}$ & Chicken meat & [137] \\
\hline & $\begin{array}{c}\text { FLU-Eu }{ }^{3+}-\mathrm{Tb}^{3+} \text {-nanocomposites } \\
\mathrm{pH}=6.9 \text { acetic acid buffered with ammonia }\end{array}$ & $255 \mathrm{~nm} / 360 \mathrm{~nm}$ & $\mathrm{LOD}=4.6 \mathrm{nM}$ & Meat samples & [138] \\
\hline Garenoxacin (GAR) & $\begin{array}{l}\text { GAR-Tb }^{3+}-\mathrm{SDS} \text { micelles- } \mathrm{Na}_{2} \mathrm{SO}_{3} \text { system; } \\
\text { pH }=4.1 \text {-acetate buffer; }\end{array}$ & $281 \mathrm{~nm} / 546 \mathrm{~nm}$ & $\begin{array}{l}\mathrm{LOD}=46.9 \mathrm{nM} ; \\
\mathrm{LOQ}=152.4 \mathrm{nM}\end{array}$ & Serum and urine samples & [89] \\
\hline \multirow[t]{4}{*}{$\begin{array}{l}\text { Gatifloxacin } \\
\text { (GFLX) }\end{array}$} & $\begin{array}{l}\text { GFLX- Eu }{ }^{3+} \text { system in acetonitrile; } \\
\text { pH }=3.5 \text { - acetate buffer; }\end{array}$ & $395 \mathrm{~nm} / 617 \mathrm{~nm}$ & $\begin{array}{l}\mathrm{LOD}=16 \mathrm{nM} ; \\
\mathrm{LOQ}=28 \mathrm{nM}\end{array}$ & $\begin{array}{c}\text { Pharma- } \\
\text { ceutical tablets, serum. }\end{array}$ & [122] \\
\hline & $\begin{array}{l}\text { GFLX-Eu }{ }^{3+}-\text { SDBS system } \\
\mathrm{pH}=7.5 \text {-Tris-HCl buffer }\end{array}$ & $338 \mathrm{~nm} / 617 \mathrm{~nm}$ & $\mathrm{LOD}=1 \mathrm{nM}$ & Injections and human urine/serum samples & [139] \\
\hline & $\begin{array}{l}\text { GFLX-Eu }{ }^{3+} \text { system in sol- gel matrix; } \\
\text { pH = } 6 \text { - borate buffer; }\end{array}$ & $370 \mathrm{~nm} / 617 \mathrm{~nm}$; & $\mathrm{LOD}=0.16 \mathrm{nM}$ & $\begin{array}{c}\text { Pharma- } \\
\text { ceutical and serum samples. }\end{array}$ & [140] \\
\hline & $\begin{array}{l}\text { GFLX-Tb }{ }^{3+} \text { system in sol-gel matrix; } \\
\text { pH =3.5-acetate buffer; }\end{array}$ & $350 \mathrm{~nm} / 545 \mathrm{~nm} ;$ & $\mathrm{LOD}=20 \mathrm{nM}$ & $\begin{array}{l}\text { Pharma- } \\
\text { ceutical and serum samples. }\end{array}$ & [140] \\
\hline \multirow[t]{2}{*}{$\begin{array}{c}\text { Grepafloxacin } \\
\text { (GREP) }\end{array}$} & $\begin{array}{l}\text { GREP-Tb } \text { S }^{3+} \text {-SDS micellar solution system; } \\
\text { pH = 6-acetate buffer; }\end{array}$ & $275 \mathrm{~nm} / 546 \mathrm{~nm}$ & $\begin{array}{l}\mathrm{LOD}=27824.5 \mathrm{nM} ; \\
\mathrm{LOQ}=83473.5 \mathrm{nM}\end{array}$ & Human serum and urine & [88] \\
\hline & $\begin{array}{c}\mathrm{GREP}-\mathrm{Tb}^{3+}-\mathrm{Ce}(\mathrm{IV})-\mathrm{Na}_{2} \mathrm{SO}_{3} \\
\mathrm{pH}=4-15 \mathrm{mM} \text { sodium dodecyl sulphate solution }\end{array}$ & $280 \mathrm{~nm} / 450 \mathrm{~nm}$ & $\mathrm{LOD}=27.8 \mathrm{nM}$ & Pharmaceutical tablets and human urine & [141] \\
\hline \multirow[t]{7}{*}{$\begin{array}{c}\text { Levofloxacin } \\
\text { (LEVO) }\end{array}$} & $\begin{array}{l}\text { LEVO-Tb }^{3+} \text { system; micellar solution of SDS; } \\
\text { pH = 6-acetate buffer; }\end{array}$ & $292 \mathrm{~nm} / 546 \mathrm{~nm}$ & $\begin{array}{l}\text { LOD }=27672.6 \mathrm{nM} ; \\
\mathrm{LOQ}=83017.8 \mathrm{nM}\end{array}$ & $\begin{array}{c}\text { Pharma- } \\
\text { ceutical tablets, human serum, urine. }\end{array}$ & [87] \\
\hline & $\begin{array}{l}\text { LEVO-Tb丶 }{ }^{3+} \text { system; colloidal silver NPs; } \\
\text { pH = 9-tris-HCl buffer; }\end{array}$ & $284 \mathrm{~nm} / 545 \mathrm{~nm}$ & $\mathrm{LOD}=7.19 \times 10^{-9} \mathrm{nM}$ & Serum samples, urine & [95] \\
\hline & $\begin{array}{c}\text { LEVO-Tb }{ }^{3+} \text {-gold NPs system; } \\
\mathrm{pH}=6.8 \mathrm{NaH}_{2} \mathrm{PO}_{4} / \mathrm{Na}_{2} \mathrm{HPO}_{4} \text { buffer; }\end{array}$ & $373 \mathrm{~nm} / 545 \mathrm{~nm}$ & $\begin{array}{l}\mathrm{LOD}=0.21 \mathrm{nM} ; \\
\mathrm{LOQ}=0.72 \mathrm{nM}\end{array}$ & Powder, tablets. & [99] \\
\hline & $\begin{array}{l}\text { LEVO-Sm }{ }^{3+} \text { system; } \\
\text { pH = 6-acetate buffer; }\end{array}$ & $312 \mathrm{~nm} / 553 \mathrm{~nm}$ & $\begin{array}{l}\mathrm{LOD}=52.5 \mathrm{nM} ; \\
\mathrm{LOQ}=154.7 \mathrm{nM}\end{array}$ & $\begin{array}{l}\text { Powder, } \\
\text { tablets }\end{array}$ & [142] \\
\hline & $\begin{array}{c}\mathrm{LEVO}-\mathrm{Eu}^{3+}-\mathrm{Ce}^{4+}-\mathrm{SO}_{3}{ }^{2-}-\mathrm{H}_{2} \mathrm{SO}_{4} \text { system; } \\
\text { (Additionally applied for moxifloxacin and trovafloxacin) }\end{array}$ & - & $\begin{array}{l}\mathrm{LOD}=276.7 \mathrm{nM} \\
\mathrm{LOQ}=968.45 \mathrm{nM}\end{array}$ & Tablets & [110] \\
\hline & $\begin{array}{c}\text { LEVO-Eu }^{3+} \text {-covalent } \\
\text { organic framework-based hybrid material }\end{array}$ & $380 \mathrm{~nm} / 613 \mathrm{~nm}$ & $\mathrm{LOD}=200 \mathrm{nM}$ & Serum and urine samples & [143] \\
\hline & LEVO-Ce(IV) in micellar solutions of of cetyltrimethyl ammonium bromide & $\begin{array}{l}250 \mathrm{~nm} / 355 \mathrm{~nm} \\
\text { (FRET method) }\end{array}$ & - & Injections & [144] \\
\hline $\begin{array}{l}\text { Lomefloxacin } \\
\text { (LOM) }\end{array}$ & $\begin{array}{l}\text { LOM-Sm }{ }^{3+} \text { system; } \\
\mathrm{pH}=6 \text { - acetate buffer; }\end{array}$ & $310 \mathrm{~nm} / 556 \mathrm{~nm}$ & $\begin{array}{l}\mathrm{LOD}=65.4 \mathrm{nM} ; \\
\mathrm{LOQ}=199 \mathrm{nM}\end{array}$ & Powder, tablets. & [142] \\
\hline
\end{tabular}


Table 4. Cont.

\begin{tabular}{|c|c|c|c|c|c|}
\hline Quinolone & Method (System, Optimum pH, Optimum Buffer Conditions) & $\lambda_{\text {exitation }} / \lambda_{\text {emission }}$ & $\begin{array}{l}\text { Limit of Detection/Limit ofQuantification } \\
\text { (LOD/LOQ) }\end{array}$ & Matrix & Ref \\
\hline & $\begin{array}{l}\text { LOM-Tb }{ }^{3+} \text {-silver NPs system; } \\
\text { pH = 6-acetate buffer; }\end{array}$ & $274 \mathrm{~nm} / 545 \mathrm{~nm}$ & $\mathrm{LOD}=0.11 \mathrm{nM} ;$ & Tablets, serum, urine samples. & {$[98]$} \\
\hline & $\begin{array}{c}\text { LOM-Tb' } \text { - }^{3+}-\mathrm{Ce}(\mathrm{IV})-\mathrm{Na}_{2} \mathrm{SO}_{3} \\
\mathrm{pH}=2-\mathrm{H}_{2} \mathrm{SO}_{4}\end{array}$ & $\begin{array}{l}\text { CL excitation/490 nm, } \\
545 \mathrm{~nm}, \\
585 \mathrm{~nm}, \\
620 \mathrm{~nm}\end{array}$ & $\mathrm{LOD}=1.1 \mathrm{nM}$ & Pharmaceutical tablets, urine and serum samples & [145] \\
\hline \multirow[t]{2}{*}{$\begin{array}{l}\text { Marbofloxacin } \\
\quad \text { (MAR) }\end{array}$} & $\begin{array}{c}\text { MAR-Tb }{ }^{3+} \text { system; } \\
\text { pH = 6.0-acetic acid/ ammonium acetate buffer; } \\
\text { (Additionally applied for: ciprofloxacin, danofloxacin, enrofloxacin, sarafloxacin, } \\
\text { difloxacin, oxolinic acid, flumequine) }\end{array}$ & $\begin{array}{l}\text { FL: } 340 \mathrm{~nm} / 545 \mathrm{~nm} ; \\
\text { TR: } 281 \mathrm{~nm} / 545 \mathrm{~nm}\end{array}$ & $\begin{array}{l}\mathrm{LOD}=165.56 \mathrm{nM}(\mathrm{FL}) \\
\mathrm{LOD}=262.17 \mathrm{nM}(\mathrm{TR})\end{array}$ & Whole, semi-skimmed, skimmed milk. & [146] \\
\hline & $\begin{array}{c}\text { MAR- } \mathrm{Tb}_{4} \mathrm{O}_{7} \text { NPs-TOPO-SDS-hexamine system; } \\
\mathrm{pH}=\text { = 7.0-7.5-Tris buffer; } \\
\text { (Applied also for: ciprofloxacin, danofloxacin, enrofloxacin, sarafloxacin, oxolinic } \\
\text { acid, fumequine). }\end{array}$ & $340 \mathrm{~nm} / 545 \mathrm{~nm}$. & $\mathrm{LOD}=96.59 \mathrm{nM}$ & $\begin{array}{l}\text { Skimmed, semi- } \\
\text { skimmed, whole milk samples. }\end{array}$ & [97] \\
\hline $\begin{array}{l}\text { Moxifloxacin } \\
\text { (MOXI) }\end{array}$ & $\begin{array}{l}\text { MOXI-Tb }{ }^{3+} \text { system; colloidal silver NPs; } \\
\text { pH = 9-Tris-HCl buffer; }\end{array}$ & $284 \mathrm{~nm} / 545 \mathrm{~nm}$ & $\mathrm{LOD}=8.47 \times 10^{-9} \mathrm{nM}$ & Serum samples, urine & [95] \\
\hline Norfloxacin (NOR) & $\begin{array}{c}\text { NOR- } \mathrm{Tb}^{3+}-\mathrm{TOPO} \text { system } \\
\mathrm{pH}=5.5-\text { acetate buffer; micellar solution of } \mathrm{CPCl}\end{array}$ & $333 \mathrm{~nm} / 490 \mathrm{~nm}$ & $\mathrm{LOD}=1.7 \mathrm{nM}$ & Serum samples & {$[85]$} \\
\hline \multirow[t]{2}{*}{$\begin{array}{l}\text { Marbofloxacin } \\
\quad \text { (MAR) }\end{array}$} & $\begin{array}{c}{\mathrm{MAR}-\mathrm{Tb}^{3+}} \text { system; } \\
\mathrm{pH}=\text { 6.0-acetic acid/ ammonium acetate buffer; } \\
\text { (Additionally applied for: ciprofloxacin, danofloxacin, enrofloxacin, sarafloxacin, } \\
\text { difloxacin, oxolinic acid, flumequine) }\end{array}$ & $\begin{array}{l}\text { FL: } 340 \mathrm{~nm} / 545 \mathrm{~nm} ; \\
\text { TR: } 281 \mathrm{~nm} / 545 \mathrm{~nm}\end{array}$ & $\begin{array}{l}\mathrm{LOD}=165.56 \mathrm{nM}(\mathrm{FL}) ; \\
\mathrm{LOD}=262.17 \mathrm{nM}(\mathrm{TR})\end{array}$ & Whole, semi-skimmed, skimmed milk. & [146] \\
\hline & $\begin{array}{c}\text { MAR- } \mathrm{Tb}_{4} \mathrm{O}_{7} \text { NPs-TOPO-SDS-hexamine system; } \\
\mathrm{pH}=\text { = 7.0-7.5-Tris buffer; } \\
\text { (Applied also for: ciprofloxacin, danofloxacin, enrofloxacin, sarafloxacin, oxolinic } \\
\text { acid, fumequine). }\end{array}$ & $340 \mathrm{~nm} / 545 \mathrm{~nm}$. & $\mathrm{LOD}=96.59 \mathrm{nM}$ & Skimmed, semi-skimmed, whole milk samples. & [97] \\
\hline $\begin{array}{c}\text { Moxifloxacin } \\
\text { (MOXI) }\end{array}$ & $\begin{array}{l}\text { MOXI-Tb }{ }^{3+} \text { system; colloidal silver NPs; } \\
\text { pH = 9-Tris-HCl buffer; }\end{array}$ & $284 \mathrm{~nm} / 545 \mathrm{~nm}$ & $\mathrm{LOD}=8.47 \times 10^{-9} \mathrm{nM}$ & Serum samples, urine & {$[95]$} \\
\hline \multirow[t]{6}{*}{ Norfloxacin (NOR) } & $\begin{array}{c}\text { NOR-Tb }{ }^{3+}-\mathrm{TOPO} \text { system } \\
\mathrm{pH}=\text { 5.5-acetate buffer; micellar solution of } \mathrm{CPCl}\end{array}$ & $333 \mathrm{~nm} / 490 \mathrm{~nm}$ & $\mathrm{LOD}=1.7 \mathrm{nM}$ & Serum samples & [85] \\
\hline & $\begin{array}{c}\text { NOR-Tb } \mathrm{Tb}^{3+} \text {-calf thymus DNA; } \\
\mathrm{pH}=\text { 5.5-acetic acid-sodium acetate buffer }\end{array}$ & $272 \mathrm{~nm} / 545 \mathrm{~nm}$ & $\mathrm{LOD}=35.8 \mathrm{nM}$ & Eye-ear pharma-ceutical dosage forms & [121] \\
\hline & $\begin{array}{l}\text { NOR-Tb }{ }^{3+}-\text { zeolite of the CaA-type } \\
\mathrm{pH}=7 \text {-buffered with a } 40 \% \text { aqueous solution of urothropine } \\
\text { (Additionally applied for ciprofloxacin) }\end{array}$ & $365 \mathrm{~nm} / 545 \mathrm{~nm}$ & $\mathrm{LOD}=3131 \mathrm{nM}$ & Urine and human plasma samples & [147] \\
\hline & $\begin{array}{l}\text { NOR- } \mathrm{Tb}^{3+}-\mathrm{Na}_{2} \mathrm{SO}_{3} \text { system } \\
\mathrm{pH}=7\end{array}$ & $\begin{array}{l}\text { ECL excitation/490 nm, } \\
545 \mathrm{~nm}, \\
585 \mathrm{~nm}, \\
620 \mathrm{~nm}\end{array}$ & $\mathrm{LOD}=0.028 \mathrm{nM}$ & Pharmaceutical capsules, urine samples & [148] \\
\hline & $\begin{array}{l}\text { NOR-Sm }{ }^{3+} \text { system; } \\
\mathrm{pH}=6 \text {-acetate buffer; }\end{array}$ & $314 \mathrm{~nm} / 553 \mathrm{~nm}$ & $\begin{array}{c}\mathrm{LOD}=84.5 \mathrm{nM} \\
\mathrm{LOQ}=253.6 \mathrm{nM}\end{array}$ & Powder, tablets & [142] \\
\hline & $\begin{array}{l}\text { NOR-Tb }{ }^{3+} \text { sodium tetradecylsulfate system; } \\
\qquad \mathrm{pH}=7-8 ;\end{array}$ & $337 \mathrm{~nm} / 545 \mathrm{~nm}$ & $\mathrm{LOD}=0.0031 \mathrm{nM}$ & Used in HELC & [149] \\
\hline
\end{tabular}


Table 4. Cont

\begin{tabular}{|c|c|c|c|c|c|}
\hline Quinolone & Method (System, Optimum pH, Optimum Buffer Conditions) & $\lambda_{\text {exitation }} / \lambda_{\text {emission }}$ & $\begin{array}{l}\text { Limit of Detection/Limit ofQuantification } \\
\text { (LOD/LOQ) }\end{array}$ & Matrix & Ref \\
\hline & $\begin{array}{c}\text { NOR-Ce }{ }^{4+} \text { system; } \\
\text { Acidic pH-perchloric acid } 0.02-0.08 \mathrm{~mol} / \mathrm{L} ;\end{array}$ & $-/ 550 \mathrm{~nm}$ & $\begin{array}{l}\mathrm{LOD}=31.3 \mathrm{nM} ; \\
\mathrm{LOQ}=93.9 \mathrm{nM}\end{array}$ & Pharma-ceutical capsules, eye drops, urine & [100] \\
\hline & $\begin{array}{c}\text { NOR-Tb }{ }^{3+}+(\text { bipy })_{2} \\
\text { (DPA)- } \mathrm{K}_{2} \mathrm{~S}_{2} \mathrm{O}_{8} \text { system; } \\
\mathrm{pH}=10-\mathrm{NaBO}_{4}-\mathrm{NaOH} \text { buffer; }\end{array}$ & $\begin{array}{c}\text { ECL excitation } / 485 \mathrm{~nm}, \\
545 \mathrm{~nm}, \\
582 \mathrm{~nm}, \\
621 \mathrm{~nm}\end{array}$ & $\mathrm{LOD}=0.69 \mathrm{nM}$ & Urine samples & [101] \\
\hline & $\begin{array}{l}\text { NOR- PEG coated } \text { Tb }^{3+} \text { doped ZnS NPs system; } \\
\text { pH = 7.6-tris-HCl buffer; }\end{array}$ & $\begin{array}{l}334 \mathrm{~nm} / 491 \mathrm{~nm}, \\
545 \mathrm{~nm}\end{array}$ & $\begin{array}{l}\mathrm{LOD}=0.05 \mathrm{nM} ; \\
\mathrm{LOQ}=0.17 \mathrm{nM}\end{array}$ & Eye drops, urine samples & [96] \\
\hline & $\begin{array}{l}\text { NOR-Tb }{ }^{3+} \text { system flow through solid phase system; } \\
\text { pH = 5.6-acetate buffer; }\end{array}$ & $273 \mathrm{~nm} / 545 \mathrm{~nm}$. & $\begin{aligned} \mathrm{LOD} & =4.7 \mathrm{nM} ; \\
\mathrm{LOQ} & =15.7 \mathrm{nM}\end{aligned}$ & Serum and urine samples. & [150] \\
\hline & $\begin{array}{l}\text { NOR-Tb }{ }^{3+}-\mathrm{KMnO}_{4}-\mathrm{Na}_{2} \mathrm{SO}_{3} \text { system-optical flow-through sensor; } \\
\mathrm{pH}=3-\mathrm{KH} \text { phthalate-HCl buffer; }\end{array}$ & CL excitation/545 nm & $\mathrm{LOD}=8.7 \mathrm{nM}$ & Pharma-ceutical samples & [102] \\
\hline & $\begin{array}{c}\text { NOR-AMP-Tb } \begin{array}{c}3+ \\
\mathrm{pH}=7.5 \mathrm{FSs} \text { system; }\end{array} \\
\text { (Additionally applied for: pefloxacin, sparfloxacin, fleroxacin, } \\
\text { nalidixic acid as well.) }\end{array}$ & $280 \mathrm{~nm} / 545 \mathrm{~nm}$ & $\mathrm{LOD}=10 \mathrm{nM}$ & Milk & [93] \\
\hline & $\begin{array}{l}\text { NOR-Tb }{ }^{3+} \text {-SDS- } \mathrm{Na}_{2} \mathrm{SO}_{3} \text { system; } \\
\mathrm{pH}=6.5 \text {-acetate buffer; }\end{array}$ & $271 \mathrm{~nm} / 545 \mathrm{~nm} ;$ & $\mathrm{LOD}=1.88 \mathrm{nM}$ & Serum samples. & [108] \\
\hline & $\begin{array}{l}\text { NOR-Tb }{ }^{3+} \text { system in sol-gel matrix; } \\
\text { pH = 3.5-acetate buffer; }\end{array}$ & $395 \mathrm{~nm} / 545 \mathrm{~nm}$; & $\mathrm{LOD}=10 \mathrm{nM}$ & Pharma-ceutical and serum samples. & [140] \\
\hline & $\begin{array}{l}\text { NOR- Eu }{ }^{3+} \text { system in sol-gel matrix; } \\
\mathrm{pH}=6 \text { - borate buffer; }\end{array}$ & $340 \mathrm{~nm} / 617 \mathrm{~nm}$; & $\mathrm{LOD}=3.0 \mathrm{nM}$ & Pharma-ceutical and serum samples. & [140] \\
\hline & $\begin{array}{l}\text { NOR fluorescence immunoassay coating-antigen-modified polystyrene par } \\
\text { anti-norfloxacin monoclonal } \\
\text { antibody conjugated with carboxyl-functionalized } \\
\text { NaYF } 4 \text { Yb, Er upconversion NPs } \\
\text { pH }=7.4 \text {-phosphate-buffered saline } \\
\end{array}$ & $980 \mathrm{~nm} / 542 \mathrm{~nm}$ & $\mathrm{LOD}=0.03 \mathrm{nM}$ & Milk, chicken, pork kidney samples & [151] \\
\hline \multirow[t]{5}{*}{ Ofloxacin (OFLO) } & $\begin{array}{l}\text { OFLO-Tb }^{3+} \text {-TTDC; } \\
\text { pH = 7-8; }\end{array}$ & $337 \mathrm{~nm} / 545 \mathrm{~nm}$ & LOD $=0.0000276 \mathrm{nM}$ & Used in HELC & [149] \\
\hline & $\begin{array}{c}\mathrm{Ce}^{4+}-\mathrm{Na}_{2} \mathrm{SO}_{3} \text {-OFLO-Tb }{ }^{3+} \text { system; } \\
\text { Acidic pH- } \mathrm{HCl} \text {. } \\
\text { Flow-injection coupled with CL detection }\end{array}$ & - & $\mathrm{LOD}=20.75 \mathrm{nM}$ & Plasma samples & [152] \\
\hline & $\begin{array}{l}\text { OFLO-Ru(bipy })_{2}(\mathrm{CIP})^{2+} \\
\mathrm{Ce}^{4+} \text { system; } \\
\text { Acidic pH }-\mathrm{HNO}_{3}\end{array}$ & $\begin{array}{c}\text { CL excitation / } 617 \mathrm{~nm}, \\
624 \mathrm{~nm}\end{array}$ & $\mathrm{LOD}=4.2 \mathrm{nM}$ & Pharma-ceutical samples, urine samples & [103] \\
\hline & $\begin{array}{l}\text { OFLO-Eu }{ }^{3+} \text { system; } \\
\mathrm{pH}=5.1 \text { - acetate buffer. }\end{array}$ & $365 \mathrm{~nm} / 617 \mathrm{~nm}$ & $\begin{array}{l}\mathrm{LOD}=3 \mathrm{nM} ; \\
\mathrm{LOQ}=9 \mathrm{nM}\end{array}$ & Pharma-ceutical and serum samples & [153] \\
\hline & $\begin{array}{l}\text { OFLO-Tb }{ }^{3+}-\mathrm{Na}_{2} \mathrm{SO}_{3} \text { system; } \\
\qquad \mathrm{pH}=7\end{array}$ & $\begin{array}{l}\text { ECL excitation } / 490 \mathrm{~nm}, \\
545 \mathrm{~nm}, \\
585 \mathrm{~nm}, \\
620 \mathrm{~nm} .\end{array}$ & $\mathrm{LOD}=0.16 \mathrm{nM}$ & Dosage forms, urine samples. & [106] \\
\hline
\end{tabular}


Table 4. Cont

\begin{tabular}{|c|c|c|c|c|c|}
\hline Quinolone & Method (System, Optimum pH, Optimum Buffer Conditions) & $\lambda_{\text {exitation }} / \lambda_{\text {emission }}$ & $\begin{array}{l}\text { Limit of Detection/Limit ofQuantification } \\
\text { (LOD/LOQ) }\end{array}$ & Matrix & Ref \\
\hline $\begin{array}{l}\text { Orbifloxacin } \\
\quad \text { (ORBI) }\end{array}$ & $\begin{array}{l}\text { ORBI-Tb }{ }^{3+} \text { system; } \\
\mathrm{pH}=6 \text {-acetate buffer; }\end{array}$ & $275 \mathrm{~nm} / 545 \mathrm{~nm}$ & $\begin{array}{l}\mathrm{LOD}=8.35 \mathrm{nM} ; \\
\mathrm{LOQ}=25.3 \mathrm{nM}\end{array}$ & $\begin{array}{l}\text { Tablets, } \\
\text { urine samples }\end{array}$ & [154] \\
\hline \multirow[t]{3}{*}{ Pazufloxacin (PAZ) } & $\begin{array}{c}\text { PAZ- } \text { Tb }^{3+} \text { system; } \\
\mathrm{pH}=6.3 \text { - acetate buffer; }\end{array}$ & $330 \mathrm{~nm} / 545 \mathrm{~nm}$ & $\mathrm{LOD}=6.2 \mathrm{nM}$ & Serum and urine samples & [155] \\
\hline & $\begin{array}{l}{\mathrm{PAZ}-\mathrm{Eu}^{3+}-\mathrm{KMnO}_{4}}_{\mathrm{KMn}^{-}} \\
\mathrm{Na}_{2} \mathrm{~S}_{2} \mathrm{O}_{4} \text { system; } \\
\mathrm{pH}=6\end{array}$ & $\begin{array}{l}\text { CL excitation/592 nm, } \\
617 \mathrm{~nm}, \\
695 \mathrm{~nm} . \\
\end{array}$ & $\mathrm{LOD}=2.6 \mathrm{nM}$ & Serum and urine samples. & [156] \\
\hline & PAZ- $\mathrm{Ce}^{4+}-\mathrm{Na}_{2} \mathrm{SO}_{3}-\mathrm{H}_{2} \mathrm{SO}_{4}$ system; & $-/ 247 \mathrm{~nm}$ & $\mathrm{LOD}=2.2 \mathrm{nM}$ & Urine samples & [157] \\
\hline \multirow[t]{3}{*}{ Pefloxacin (PEF) } & $\begin{array}{c}\text { PEF-Tb }{ }^{3+} \text {-TOPO system; } \\
\mathrm{pH}=5.5 \text {-acetate buffer; micellar solution of } \mathrm{CPCl}\end{array}$ & $333 \mathrm{~nm} / 590 \mathrm{~nm}$ & $\mathrm{LOD}=4.4 \mathrm{nM}$ & Serum samples & [85] \\
\hline & 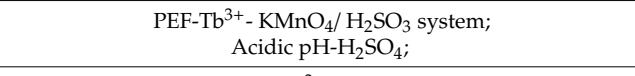 & CL excitation $/ 543 \mathrm{~nm}$ & $\mathrm{LOD}=41.1 \mathrm{nM}$ & Semi-skimmed milk samples & {$[107]$} \\
\hline & $\begin{array}{l}\text { PEF-Tb } \mathrm{b}^{3+} \text {-Ag NPs } \\
\mathrm{pH}=6 \text {-acetate buffer }\end{array}$ & $273 \mathrm{~nm} / 545 \mathrm{~nm}$ & $\mathrm{LOD}=25 \mathrm{nM}$ & Pharmaceutical capsules and serum samples & [158] \\
\hline \multirow[t]{2}{*}{$\begin{array}{c}\text { Pipemidic acid } \\
\text { (PPA) }\end{array}$} & $\begin{array}{l}\text { PPA-Tb } b^{3+}-\mathrm{Ag}^{+} \mathrm{NPs} \text { system; } \\
\text { pH = 6-acetate buffer; }\end{array}$ & $320 \mathrm{~nm} / 545 \mathrm{~nm}$. & $\mathrm{LOD}=0.047 \mathrm{nM}$ & Tablets, serum, urine samples. & [98] \\
\hline & $\begin{array}{c}\text { PPA-Tb }{ }^{3+} \text { system; } \\
\mathrm{pH}=5.6 \text { - acetate buffer; }\end{array}$ & $320 \mathrm{~nm} / 545 \mathrm{~nm}$. & $\mathrm{LOD}=5.9 \mathrm{nM}$ & Urine and serum samples & [159] \\
\hline \multirow[t]{2}{*}{$\begin{array}{l}\text { Prulifloxacin } \\
\text { (PUFX) }\end{array}$} & $\begin{array}{c}\quad \text { PUFX- } \mathrm{Tb}^{3+}-\mathrm{KMnO}_{4}-\mathrm{Na}_{2} \mathrm{~S}_{2} \mathrm{O}_{4} \text { system; } \\
\qquad \mathrm{pH}=5.8 \text { i } \\
\text { (Additionally applied for ulifloxacin }-\mathrm{pH}=5.4 \text { ) }\end{array}$ & $\begin{array}{l}\text { CL excitation/490 nm, } \\
545 \mathrm{~nm}, \\
585 \mathrm{~nm}, \\
620 \mathrm{~nm} .\end{array}$ & $\mathrm{LOD}=7 \mathrm{nM}$ & Tablets & [160] \\
\hline & $\begin{array}{c}\text { PUFX- }-\mathrm{Tb}^{3+}-\mathrm{KMnO}_{4}-\mathrm{Na}_{2} \mathrm{SO}_{3} \\
\mathrm{KH}_{2} \mathrm{PO}_{4}-\mathrm{NaOH} \text { buffer }\end{array}$ & $275 \mathrm{~nm} / 423 \mathrm{~nm}$ & $\mathrm{LOD}=8 \mathrm{nM}$ & $\begin{array}{l}\text { Pharmaceutical tablets, serum, and urine } \\
\text { samples }\end{array}$ & {$[161]$} \\
\hline Ulifloxacin (UFX) & $\begin{array}{l}\text { UFX-Eu }{ }^{3+}+\text { SDBS system; } \\
\mathrm{pH}= \\
\text { 8.6- }-\mathrm{NH}_{4} \mathrm{Cl} / \mathrm{NH}_{3} \times \mathrm{H}_{2} \mathrm{O} \text { buffer; }\end{array}$ & $276 \mathrm{~nm} / 616 \mathrm{~nm}$. & $\mathrm{LOD}=0.2 \mathrm{nM}$ & Human serum and urine & [162] \\
\hline
\end{tabular}

LOD = limit of detection; LOQ = limit of quantification; Ad = adenine; AMP = adenosine monophosphate; Bipy = 2,2'-bipyridyl; CIP = 4-carboxyl-imidazole [4,5-f $]$

$[1,10]$-phenanthroline; DPA $=2,6$-pyridinedicarbocylic acid; $\mathrm{CPCl}=$ cetylpiridinium chloride; $\mathrm{CL}=$ chemiluminescence; $\mathrm{ECL}=$ electrochemiluminescence; $\mathrm{NPs}=$ nanoparticles;

CPNPs = coordination polymer nanoparticles; CPNSs = coordination polymer nanosheets; CTAB = cetyltrimethylammonium bromide; DDBS = sodium dodecyl-benzensulfonate;

DO3A = 1,4,7,10-tetraazacyclododecane-1,4,7-triacetic acid; FL = fluorescence; TR = time-resolved fluorescence; GMP = guanosine-5-monophosphate; HELC = high-efficiency liquid chromatography; HEPES = N-2-hydroxyethyl piperazine- $N^{\prime}$-2-ethanesulfonic acid; Phen =1,10-phenanthroline; SDS = sodium dodecyl sulphate; SDBS = sodium dodecylbenzene sulfonate; SLS = sodium laurylsulphate; TOPO = tri-n-octylphosphine oxide; TTDC = sodium tetradecylsulfate; FRET = fluorescence resonance energy transfer. 
The source of the electromagnetic radiation necessary to obtain the excited state of the ligand is either the Xe lamp of the spectrofluorometer, or a chemical species in an excited state, such as $\mathrm{SO}_{2}{ }^{*}$ obtained through a chemical reaction (chemiluminiscence). Numerous methods have been developed for the determination of quinolones [100-109], based on the formation of an excited and unstable chemical species in a redox system. This chemical species emits radiation capable of being absorbed by the fluoroquinolone. Several notable systems and mechanisms have been described as follows: the systems are formed from an oxidant, such as $\mathrm{Ce}^{4+}$ or $\mathrm{KMnO}_{4}$, in an acidic medium, and a sulfur containing a reducing agent, such as $\mathrm{S}_{2} \mathrm{O}_{4}{ }^{2-}, \mathrm{S}_{2} \mathrm{O}_{3}{ }^{2-}$ or $\mathrm{Na}_{2} \mathrm{SO}_{3}$, which will eventually generate the excited $\mathrm{SO}_{2}{ }^{*}$ species. This species emits at a wavelength around $350 \mathrm{~nm}$ at which the fluoroquinolone is able to absorb [101]. Some interesting examples are given below:

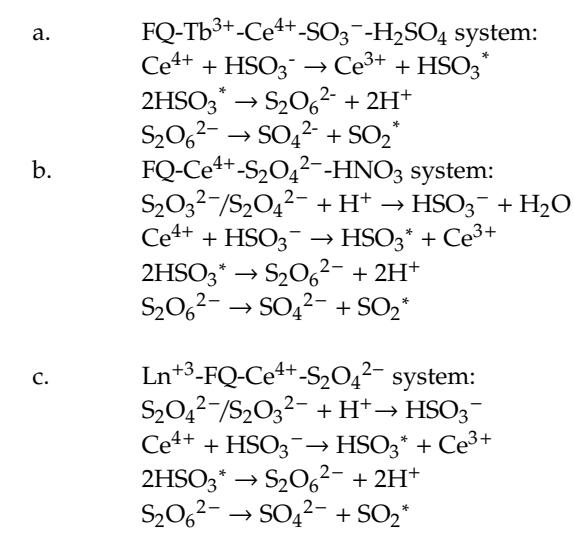

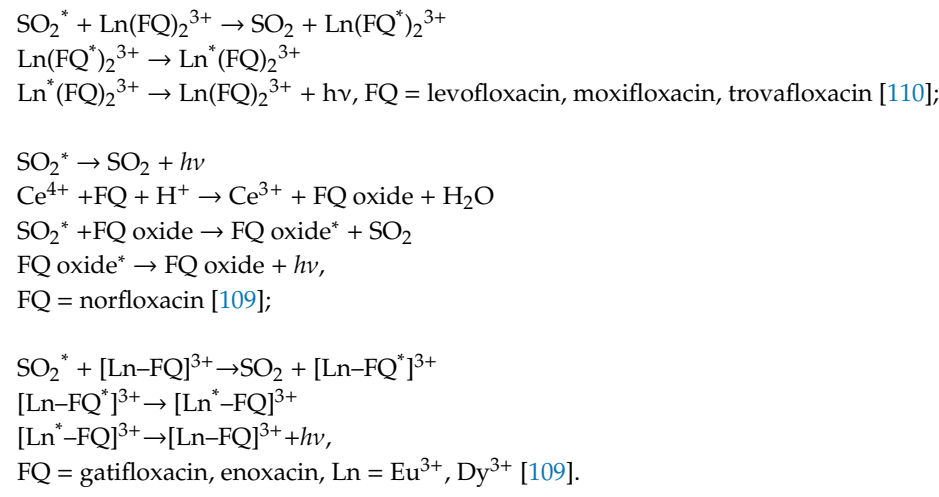

It is well-known that the evaluation of the performance of these methods is concerned with the accurate response to target fluoroquinolones in the presence of other coexisting antibiotics and chemotherapeutics. Thus, the selectivity of the methods has been tested based on possible interferences with other various chemical species; e.g., metal ions, penicillins, cephalosporins, amino-glycosides, macrolides, ionophores and sulfonamides [117,122,138,163]. For instance, selective and sensitive detection in serum and urine has been reported for a fleroxacin "turn-on" sensing device; namely, the $\mathrm{Eu}^{3+}-\mathrm{Pb}-\mathrm{MOF}$ system, where $\mathrm{MOF}=$ metal organic framework, $\left[(\mathrm{Me})_{4} \mathrm{~N}_{2}\left[\mathrm{~Pb}_{6} \mathrm{~K}_{6}(\mathrm{~m}-\mathrm{BDC})_{9}(\mathrm{OH})_{2}\right] \cdot \mathrm{H}_{2} \mathrm{O}\right.$, where 1,3- $\mathrm{H}_{2} \mathrm{BDC}=1,3$-benzenedicarboxylic acid), $\lambda_{\mathrm{em}}=612 \mathrm{~nm}\left(\lambda_{\mathrm{exc}}=377 \mathrm{~nm}\right)$. The detection limit for fleroxacin is low $(118 \mathrm{nM})$ and the sensor possesses high selectivity for fleroxacin, as opposed to the other seven fluoroquinolones tested; high antidisturbance ability to other chemicals in human serum and urine has also been reported. The probe was also proven to be stable in aqueous solutions of $\mathrm{pH}$ values ranging from 4.0 to 8.3 [134].

\subsection{Quantitative Determination of Lanthanide and Miscellaneous Ions}

Norfloxacin was used to determine erbium, holmium and neodymium in the presence of cetylpiridinium chloride by recording the second derivative spectrum of absorbance. The effect of interfering cations was also tested [164].

The $\mathrm{Eu}^{3+}-\mathrm{La}^{3+}$-gatifloxacin-SDBS system has been found appropriate to determine trace amounts of europium. Optimum conditions were tested and applied. In order to explain the luminescence enhancement mechanism, the group recorded UV-absorption spectra, determined the surface tension and the microviscosity of the aqueous system and concluded that the quaternary complex was formed in a highly viscous and hydrophobic medium with no water molecules to quench the luminescence through radiationless vibrations. Therefore, the complex was able to fully transform the absorbed energy into luminescence [165].

Other cations can also be determined using lanthanide-quinolone complexes. For instance, a method that makes use of the quenching effect of $\mathrm{Cu}^{2+}$ on the luminescence of a $\mathrm{Tb}^{3+}$-quinolone 
complex has been reported for the quantitative determination of $\mathrm{Cu}^{2+}$ ions from tap water samples. This method enabled the detection of $\mathrm{Cu}^{2+}$ ions in a nanomolar range. Further studies show that the quenching mechanism is a static one, the $\mathrm{Cu}^{2+}$ ions being able to bind to the nitrogen atoms of the thiazolidine ring, thereby coordinating it and forming a complex that is not fluorescent in ground state [166].

Another use for the phenomenon of complex formation is the extraction of a metal from a medium in the presence of different cations and anions. The complex formed by nalidixic acid with $\mathrm{Sc}^{3+} \mathrm{was}^{3}$ used for the extraction of the latter from dichloromethane, in the presence of various lanthanides or transition metal cations. After separation, the metal concentration of each phase was determined radiometrically. The results of this study in terms of selectivity, recycling ability and loading capacity were reported to be excellent under the stated optimized conditions [167].

Quantitative determination of anions by similar methods has also been reported. The luminescence quenching effect of the phosphate anion on the $\mathrm{Tb}^{3+}$-4-hydroxy-1-methyl-2-oxo-1,2-dihydro-quinoline-3-carboxylic acid-ethyl-[1,3,4]thiadiazol-2-yl) amide was used in order to determine the former. The system was analyzed in aqueous solution, at a $\mathrm{pH}$ value of 7.4, using $\lambda_{\mathrm{ex}}=320 \mathrm{~nm}$ and $\lambda_{\mathrm{em}}=548 \mathrm{~nm}$. This method allows for the determination of phosphate anions in the micromolar range. Further tests indicate that the quenching mechanism is a static one [168].

The data describing these methods have been reported in Table 5.

\subsection{Determination of Nucleic Acids}

Fluorescent methods for the determination of DNA and RNA have been extensively used $[169,170]$, despite of their downside; namely, the toxic effects of the commonly used dyes, such as ethidium bromide (EB), Hoechst 33258, YOYO, TOTO and phosphine 3R, on humans and the environment [171].

The fluorescence of the quinolone-lanthanide complexes is not only used for the determination of quinolones, but also for organic compounds of biological interest, such as nucleic acids. Highly sought traits of these complexes for the determination of nucleic acids are listed as: high luminescence, large quantum yield, high kinetic stability and good water solubility [172].

Furthermore, several terbium complexes have been reported as suitable candidates for the quantitation of DNA. The structure of the ligand was optimized (including the addition of sidechains containing a quaternary ammonium group) in order to enhance the solubility of the complexes in aqueous buffers, and to enable DNA intercalative binding. DNA binding was found to occur by means of hydrogen bonds formed between the non-divided electron pairs of the nitrogen atoms in DNA and the quaternary ammonium group. The most efficient ligand was found to be $\mathrm{N}$-[2-(diethylamino)ethyl]-4-hydroxy-2-oxo-1-propyl-1,2-dihydro-3-quinolinecarboxamide. Interestingly, an increase of up to 10-fold in luminescence of its complex with $\mathrm{Tb}^{3+}$ was observed upon titration with DNA. The method displays comparable sensitivity to the EB method. Moreover, in contrast to other techniques reported for DNA determination that employ lanthanide complexes, the addition of surfactants or other luminescence enhancers was found to be unnecessary [172].

A $\mathrm{Tb}^{3+}$-prulifloxacin complex was used to determine herring sperm DNA (hsDNA). The method, using a 2:1 ligand to ion ratio and $\mathrm{pH}=6.3$, proved to be more stable, less toxic to the environment and highly sensitive. The limit of detection obtained for DNA was $2.1 \times 10^{-9} \mathrm{~g} / \mathrm{L}$ [172]. The intercalative binding of the complex to the DNA molecule was proven using $R u(b p y)_{2}(\mathrm{dppz})^{2+}$, a known DNA intercalator [173]. 
Table 5. Determination of miscellaneous ions using lanthanide-quinolone systems.

\begin{tabular}{|c|c|c|c|c|c|}
\hline Ion & Quinolone & Conditions & $\lambda_{\text {absorption }}$ & LOD/LOQ & Ref \\
\hline $\mathrm{Er}^{3+}$ & Norfloxacin & $\begin{array}{l}\text {-Cetylpyridinium chloride; } \\
-\mathrm{pH}=9.35-\mathrm{NH}_{4} \mathrm{Cl} / \mathrm{NH}_{3} \text { buffer; }\end{array}$ & $\begin{array}{c}515(+) \mathrm{nm}, \\
517(-) \mathrm{nm} \text { (second derivative spectrum) }\end{array}$ & $\mathrm{LOD}=6.6 \times 10^{-6} \mathrm{~mol} / \mathrm{L}$ & {$[164]$} \\
\hline $\mathrm{Eu}^{3+}$ & Gatifloxacin & $\begin{array}{l}\text {-SDBS micelle solution, } \mathrm{La}^{3+} \\
\text {-pH }=7-\mathrm{NH}_{4} \mathrm{Ac}-\mathrm{NH}_{3}{ }^{*} \mathrm{H}_{2} \mathrm{O} \text { buffer; }\end{array}$ & $\begin{array}{l}\lambda_{\mathrm{ex}}=336 \mathrm{~nm} / \\
\lambda_{\mathrm{em}}=616 \mathrm{~nm}\end{array}$ & $\mathrm{LOD}=7 \times 10^{-14} \mathrm{~mol} / \mathrm{L}$ & {$[165]$} \\
\hline $\mathrm{Ho}^{3+}$ & Norfloxacin & $\begin{array}{l}\text {-Cetylpyridinium chloride; } \\
\text { - } \mathrm{pH}=9.35-\mathrm{NH}_{4} \mathrm{Cl} / \mathrm{NH}_{3} \text { buffer; }\end{array}$ & $\begin{array}{c}444(+) \mathrm{nm}, \\
446(-) \mathrm{nm} \\
\text { (second derivative spectrum) }\end{array}$ & $\mathrm{LOD}=6.6 \times 10^{-6} \mathrm{~mol} / \mathrm{L}$ & {$[164]$} \\
\hline $\mathrm{Nd}^{3+}$ & Norfloxacin & $\begin{array}{l}\text {-Cetylpyridinium chloride; } \\
-\mathrm{pH}=9.35-\mathrm{NH}_{4} \mathrm{Cl} / \mathrm{NH}_{3} \text { buffer; }\end{array}$ & $\begin{array}{c}570(+) \mathrm{nm}, \\
568(-) \mathrm{nm} \\
\text { (second derivative spectrum) }\end{array}$ & $\mathrm{LOD}=6.7 \times 10^{-6} \mathrm{~mol} / \mathrm{L}$ & [164] \\
\hline $\mathrm{Cu}^{2+}$ & $\begin{array}{c}\text { 1-methyl-4-hydroxy- } \\
\text { 3-(N-2-ethyl-5- aminothiadazolyl-)- } \\
\text { carbamoyl- } \\
\text { quinoline-2-one }\end{array}$ & -pH = 7-MOPS buffer; & $\begin{array}{l}\lambda_{\mathrm{ex}}=320 \mathrm{~nm} / \\
\lambda_{\mathrm{em}}=547 \mathrm{~nm}\end{array}$ & $\mathrm{LOD}=4.3 \times 10^{-9} \mathrm{~mol} / \mathrm{L}$ & {$[166]$} \\
\hline $\mathrm{Sc}^{3+}$ & Nalidixic acid & $\begin{array}{l}\text {-Method used for the extraction of } \mathrm{Sc}^{3+} \\
\text {-pH }=3.4 ; \\
\text {-dicholoromethane; }\end{array}$ & & $\begin{array}{l}\mathrm{SF}=1.4 \times 10^{4}\left(\mathrm{from} \mathrm{Eu}^{3+}\right) \\
\mathrm{SF}=3.6 \times 10^{3}\left(\text { from Nd }^{3+}\right)\end{array}$ & {$[167]$} \\
\hline $\begin{array}{l}\mathrm{H}_{2} \mathrm{PO}_{4}^{-} \\
\mathrm{HPO}_{4}^{-2}\end{array}$ & $\begin{array}{l}\text { 4-Hydroxy-1-methyl-2-oxo-1,2-dihydro-quinoline-3-carboxylic } \\
\text { acid-ethyl-[1,3,4]thiadiazol-2-yl) amide }\end{array}$ & $\begin{array}{l}-\mathrm{pH}=7.4 \text {-HEPES buffer; } \\
-\mathrm{Tb}^{3+} \text { complex-Triton X-100 system; }\end{array}$ & $\begin{array}{l}\lambda_{\mathrm{ex}}=320 \mathrm{~nm} / \\
\lambda_{\mathrm{em}}=548 \mathrm{~nm}\end{array}$ & $\mathrm{LOD}=110 \times 10^{-9} \mathrm{~mol} / \mathrm{L}$ & {$[168]$} \\
\hline
\end{tabular}


Calf, herring and salmon sperm DNA were determined using the complex of $\mathrm{Eu}^{3+}$ with gatifloxacin in the ratio 1:3.1, at $\mathrm{pH}=6.5$ buffered with hexamethylenamine- $\mathrm{HCl}$ solution. Upon adding the DNA sample, a 6-fold increase in the fluorescence was observed. The influence of the ionic strength on the fluorescence of the system hinted at an electrostatic interaction between the complex and DNA. Interestingly, the fluorescence enhancement mechanism was explained as follows: the coordination number of $\mathrm{Eu}^{3+}$ is eight; therefore, three gatifloxacin molecules and two water molecules are needed to saturate it; the water molecules partially absorb the energy transferred from the excited state of gatifloxacin to $\mathrm{Eu}^{3+}$, causing a drop in the fluorescence signal. The DNA molecule can displace the $\mathrm{H}_{2} \mathrm{O}$ molecules and bind $\mathrm{Eu}^{3+}$ either by complexation (via $\mathrm{O}$ and $\mathrm{N}$ ) or by means of electrostatic interactions with the phosphate groups. Thus, the loss of the water molecules, and implicitly the decrease in energy loss through the O-H vibration, results in a stronger fluorescent signal [174].

In a similar manner, the complex of difloxacin with $\mathrm{Tb}^{3+}$ was used for the determination of both single-stranded and double-stranded DNA from calf thymus, herring and salmon sperm. The binding propensity towards double-stranded DNA was higher than towards single-stranded DNA. The influence of the ionic strength of the solution upon the emission spectra and EB displacement assay were employed in order to investigate the mechanism of DNA binding. The results suggest that the Tb-difloxacin complex binds DNA via electrostatic interactions with the phosphate groups and groove binding [175].

Furthermore, fluorescent properties can be enhanced by attaching the lanthanide complex to an oligonucleotide [176,177]. Oligonucleotide probes are single-stranded nucleic acid fragments that are modified to have high specificities and affinities for certain targets, such as nucleic acids, proteins, small molecules and ions. They can be divided into two categories: hybridization probes which are based on the formation of complementary base pairs and aptamer probes which exploit selective recognition of non-nucleic acid analytes by binding to them as to a 3D receptor. Binding of the analyte to the bioreceptor can generate an analytical signal using fluorescent groups that are covalently bound to the predefined oligonucleotide. The advantages of using fluorescent labels are their high specificity and their ability to be used in assays that interpret the fluorescence signal in various ways: quenching or enhancement, anisotropy, lifetime, resonance energy transfer and the excimer-monomer light switch [178].

Luminescent terbium $\mathrm{SiO}_{2}$ nanoparticles covered with a lanthanide complex were used for DNA determination. This complex consists of a quinolone-based dye (Carbostyril 124, Cs124), one of the most efficient energy-transfer donors for terbium and europium, and a polyaminocarboxylate-based chelator which has excellent water solubility and high lanthanide binding affinity. The complex was then hybridized by attaching it to an oligonucleotide. The detection sensitivity of this method proved to be more than 100-fold higher in comparison to the fluorescein isothiocyanate method [179].

In a similar manner, diethylenetriaminepentaacetic acid (DTPA) was attached to 7-amino quinolones in order to obtain DTPA-cs124 derivatives (DTPA-cs214-CF - NCS and DTPA-cs124-NCS); $\mathrm{Tb}^{3+}, \mathrm{Eu}^{3+}, \mathrm{Dy}^{3+}$ and $\mathrm{Sm}^{3+}$ cations were used for complexation. The probes were hybridized with oligonucleotides complementary to the DNA sequence of interest. The detection limit is reported to be 0.5-1 × 10 $0^{-12} \mathrm{~mol} / \mathrm{L} \mathrm{[177].}$

The data describing these methods have been displayed in Table 6. 
Table 6. Determination of DNA using quinolone-lanthanide systems.

\begin{tabular}{|c|c|c|c|c|c|c|}
\hline Type of Nucleic Acid & Ligand (L) & $\begin{array}{l}\text { Lanthanide } \\
\text { Ion }\left(\operatorname{Ln}^{3+}\right)\end{array}$ & Conditions ( $\mathrm{pH}, \mathrm{L}: \mathrm{Ln}^{3+}$ ) & $\lambda \mathrm{ex} / \lambda \mathrm{em}$ & LOD/LOQ & Ref \\
\hline fs-DNA & Quinolone derivative & $\mathrm{Tb}^{3+}$ & $\begin{array}{l}\text {-pH = 9-Tris- } \\
\mathrm{HCl} \text { buffer; } \\
-1: 1\end{array}$ & $340 \mathrm{~nm} / 545 \mathrm{~nm}$ & $12 \mathrm{ng} / \mathrm{mL}$; & [172] \\
\hline ct-DNA & Quinolone derivative & $\mathrm{Tb}^{3+}$ & $\begin{array}{l}-\mathrm{pH}=9 \text {-Tris- } \mathrm{HCl} \text { buffer; } \\
-1: 1 ;\end{array}$ & $340 \mathrm{~nm} / 545 \mathrm{~nm}$ & $10 \mathrm{ng} / \mathrm{mL}$ & [172] \\
\hline ct-DNA & Danoflaxacin & $\mathrm{Tb}^{3+}$ & $\begin{array}{l}-\mathrm{pH}=7.8 \text {-Tris- } \\
\text { HCl buffer; }\end{array}$ & $347 \mathrm{~nm} / 545 \mathrm{~nm}$ & $8 \mathrm{ng} / \mathrm{mL}$ & [180] \\
\hline hs-DNA & Prulifloxacin & $\mathrm{Tb}^{3+}$ & $\begin{array}{l}-\mathrm{pH}=6.3 \text {-Tris- } \mathrm{HCl} \text { buffer; } \\
-2: 1\end{array}$ & $345 \mathrm{~nm} / 545 \mathrm{~nm}$ & $2.1 \mathrm{ng} / \mathrm{mL}$ & [171] \\
\hline cf-DNA & Gatifloxacin & $\mathrm{Eu}^{3+}$ & $\begin{array}{l}-\mathrm{pH}=6.5-\mathrm{HMA}-\mathrm{HCl} \text { buffer; } \\
-3.1: 1\end{array}$ & $331 \mathrm{~nm} / 617 \mathrm{~nm}$ & $6 \times 10^{-9} \mathrm{~g} / \mathrm{mL}$ & [174] \\
\hline ds-DNA & Difloxacin & $\mathrm{Tb}^{3+}$ & $\begin{array}{l}\text {-pH = 7.4-MOPS buffer; } \\
-1: 1\end{array}$ & $340 \mathrm{~nm} / 545 \mathrm{~nm}$ & $0.5 \mathrm{ng} / \mathrm{mL}$ & [175] \\
\hline ss-DNA & Difloxacin & $\mathrm{Tb}^{3+}$ & $\begin{array}{l}\text {-pH = 7.4-MOPS buffer; } \\
-1: 1\end{array}$ & $340 \mathrm{~nm} / 545 \mathrm{~nm}$ & $2 \mathrm{ng} / \mathrm{mL}$ & [175] \\
\hline Oligo-nucleotides & $\begin{array}{l}\text { Cs124-TPA- } \\
\text { Tb NPs }\end{array}$ & $\mathrm{Tb}^{3+}$ & $-\mathrm{pH}=7.5$ & $328 \mathrm{~nm} / 546 \mathrm{~nm}$ & $8 \times 10^{-11} \mathrm{~mol} / \mathrm{L}$ & [179] \\
\hline $\begin{array}{c}\text { Oligo- } \\
\text { nucleotides }\end{array}$ & 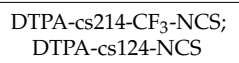 & $\begin{array}{l}\mathrm{Tb}^{3+}, \mathrm{Eu}^{3+} \\
\mathrm{Dy}^{3+}, \mathrm{Sm}^{3+}\end{array}$ & & & $0.5-1 \times 10^{-12} \mathrm{~mol} / \mathrm{L}$ & [177] \\
\hline
\end{tabular}

\subsection{Other Applications}

Fluorescence properties can be used to measure the stability constants of metal-fluoroquinolone complexes, and to elucidate, to some extent, the structures of these complexes. The difference in fluorescence spectra between the free acidic ligand-conjugated form and/or the complex ligand can give information about ligand protonation and the stability of the complex.

Spectrofluorimetric titrations are carried out by additions of known quantities of the metal ion to the buffered solutions of the ligand, while registering the fluorescence maximum increase, decrease or shift, depending on the metal and the complex formed [181]. Luminescence enhancement due to complex formation can be briefly explained as follows: (a) the extended $\pi-\pi$ ring conjugation in the complex results in fluorescent enhancement; (b) free rotation of the carboxylate or the hydroxyl of the carboxylate group is inhibited, a phenomenon which decreases the non-radiative energy loss; (c) the short distance between the metal ion and the ligand enhances the energy transfer and the blue-shift of the maximal fluorescence wavelength.

Furthermore, $\mathrm{Tb}^{3+}$ and $\mathrm{Eu}^{3+}$ complexes with ciprofloxacin and ofloxacin, respectively, were used to stain sections of normal and malignant tissues from oral cavities and stomachs (Figure 7). Transformed-infrared (FT-IR) and fluorescence spectroscopy studies revealed that ATP coordinates to $\mathrm{Eu}^{3+}$ and $\mathrm{Tb}^{3+}$, releasing free ciprofloxacin and ofloxacin; other interactions include hydrogen bonds between the chelates and the biomolecules, and coulomb forces between the negatively charged carboxyl groups of the biomolecules and $\mathrm{NH}_{2}{ }^{+}$groups of the quinolones. Moreover, it was observed that the complex is absorbed differently in distinct tissues, which helps to differentiate the tissues. Compared to the traditional hematoxylin and eosin coloring technique, the fluorescence staining method is very fast; the samples can be preserved at room temperature for at least two years; on the downside, this method needs a more expensive fluorescent optical microscope compared to the optical microscope used for the traditional method [182].

$\mathrm{An} \mathrm{u}^{3+}$-ofloxacin complex, able to change its color depending on the $\mathrm{pH}$ variation of the medium, and which is completely water-soluble, was incorporated into a polyvinyl alcohol matrix, making possible the development of two lanthanide luminescent hydrogels (rod-shaped and film) [183].

The complexes formed between an ofloxacin derivative with $\mathrm{Pr}^{3+}$ and $\mathrm{Nd}^{3+}$ were used to evaluate the interaction with bovine serum albumin (BSA) based on the quenching of its luminescence at $341 \mathrm{~nm}$. Experiments proved that the quenching was a static process due to hydrophobic and electrostatic interactions which could induce conformational changes to BSA [55]. 

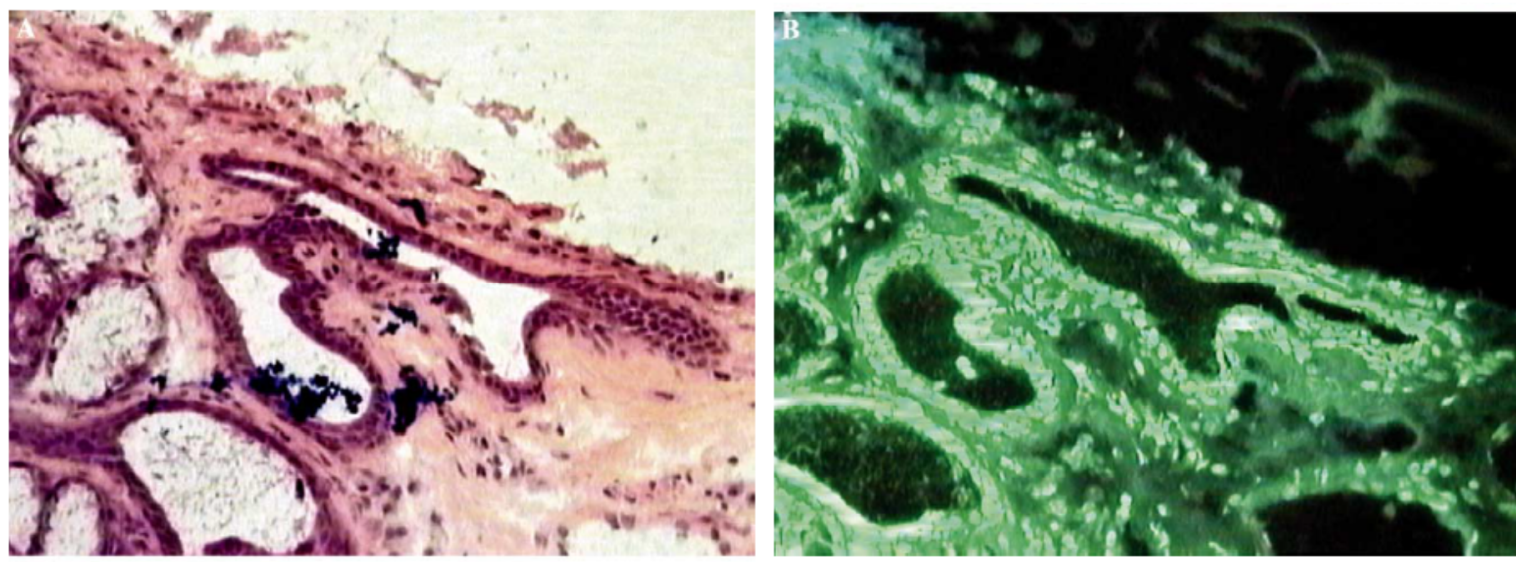

Figure 7. (a) Hematoxylin and eosin coloring technique. (b) Coloring with quinolone-lanthanide complexes, with permission from [182].

The interaction between $\mathrm{Ce}^{3+}$ ions and carbonyl group was used in order to synthesize some quinolone antibiotic norfloxacin analogues through a new pathway [184].

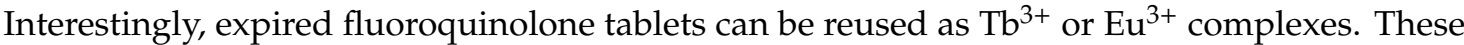
metal complexes were ultimately incorporated into homogenous films for greenhouses and used for converting UV light $(366 \mathrm{~nm})$ into visible light $(615 \mathrm{~nm})$ that can be used by plants in the photosynthesis process [185].

\section{Conclusions}

The field of lanthanide-quinolone complexes aims to develop new candidates that are more active than the free ligand, which could be useful in the fight against bacterial or tumoral resistance, and has applications in analytical determinations and tissue imaging. Despite the progress made over the last decade in developing new biologically relevant quinolone-lanthanide metal complexes, in the past two years a decrease in the number of publications has been observed. With little explored to date, metal complexes with mixed ligands (e.g., 1,10-phenantroline, 2,2'-dipyridyl) and the nanocomplexes show great promise as a future area of research, based on their biological activities.

On the other hand, the phenomenon of complex formation and the luminescent properties of the resultant compounds are still in focus, the main application being the quantitative determinations of quinolones based on their reactions with lanthanide ions. Likewise, quantitative determination of metal ions based on their reactions with lanthanides, determinations of nucleic acids and staining sections of normal and malignant tissues for fluorescence spectroscopy, have also been investigated.

Funding: This research was funded by "Carol Davila" University of Medicine and Pharmacy through Contract no. 23PFE/17.10.2018 funded by the Ministry of Research and Innovation within PNCDI III, Program 1 - Development of the National RD system, Subprogram 1.2 - Institutional Performance - RDI excellence funding projects.

Conflicts of Interest: The authors declare no conflict of interest. The funders had no role in the design of the study; in the collection, analyses, or interpretation of data; in the writing of the manuscript, or in the decision to publish the results.

\section{References}

1. Zhang, G.-F.; Zhang, S.; Pan, B.; Liu, X.; Feng, L.-S. 4-Quinolone derivatives and their activities against Gram positive pathogens. Eur. J. Med. Chem. 2018, 143, 710-723. [CrossRef]

2. Kocsis, B.; Domokos, J.; Szabo, D. Chemical structure and pharmacokinetics of novel quinolone agents represented by avarofloxacin, delafloxacin, finafloxacin, zabofloxacin and nemonoxacin. Ann. Clin. Microbiol. Antimicrob. 2016, 15, 34. [CrossRef] [PubMed]

3. Dhiman, P.; Arora, N.; Thanikachalam, P.V.; Monga, V. Recent advances in the synthetic and medicinal perspective of quinolones: A review. Bioorg. Chem. 2019, 92, 103291. [CrossRef] [PubMed] 
4. Lesher, G.Y.; Froelich, E.J.; Gruett, M.D.; Bailey, J.H.; Brundage, R.P. 1,8-Naphthyridine derivatives. A new class of chemotherapeutic agents. J. Med. Pharm. Chem. 1962, 91, 1063-1065. [CrossRef] [PubMed]

5. Ball, P.; Fernald, A.; Tillotson, G. Therapeutic advances of new fluoroquinolones. Expert Opin. Investig. Drugs 1998, 7, 761-783. [CrossRef] [PubMed]

6. Pham, T.D.M.; Ziora, Z.M.; Blaskovich, M.A.T. Quinolone antibiotics. Medchemcomm 2019, 10, 1719-1739. [CrossRef] [PubMed]

7. Andriole, V.T. The quinolones: Past, present, and future. Clin. Infect. Dis. 2005, 41, S113-S119. [CrossRef]

8. Uivarosi, V. Metal Complexes of Quinolone Antibiotics and Their Applications: An Update. Molecules 2013, 18, 11153-11197. [CrossRef]

9. Nagaraja, V.; Godbole, A.A.; Henderson, S.R.; Maxwell, A. DNA topoisomerase I and DNA gyrase as targets for TB therapy. Drug Discov. Today 2017, 22, 510-518. [CrossRef]

10. Charrier, C.; Salisbury, A.-M.; Savage, V.J.; Duffy, T.; Moyo, E.; Chaffer-Malam, N.; Ooi, N.; Newman, R.; Cheung, J.; Metzger, R.; et al. Novel Bacterial Topoisomerase Inhibitors with Potent Broad-Spectrum Activity against Drug-Resistant Bacteria. Antimicrob. Agents Chemother. 2017, 61, e02100-16. [CrossRef]

11. Kato, J.; Nishimura, Y.; Imamura, R.; Niki, H.; Hiraga, S.; Suzuki, H. New topoisomerase essential for chromosome segregation in E. coli. Cell 1990, 63, 393-404. [CrossRef]

12. Idowu, T.; Schweizer, F. Ubiquitous Nature of Fluoroquinolones: The Oscillation between Antibacterial and Anticancer Activities. Antibiotics 2017, 6, 26. [CrossRef] [PubMed]

13. Papillon, J.; Ménétret, J.-F.; Batisse, C.; Hélye, R.; Schultz, P.; Potier, N.; Lamour, V. Structural insight into negative DNA supercoiling by DNA gyrase, a bacterial type 2A DNA topoisomerase. Nucleic Acids Res. 2013, 41, 7815-7827. [CrossRef] [PubMed]

14. Klostermeier, D. Why Two? On the Role of (A-)Symmetry in Negative Supercoiling of DNA by Gyrase. Int. J. Mol. Sci. 2018, 19, 1489. [CrossRef]

15. Ashley, R.E.; Dittmore, A.; McPherson, S.A.; Turnbough, C.L., Jr.; Neuman, K.C.; Osheroff, N. Activities of gyrase and topoisomerase IV on positively supercoiled DNA. Nucleic Acids Res. 2017, 45, 9611-9624. [CrossRef]

16. Wang, J.C. Cellular roles of DNA topoisomerases: A molecular perspective. Nat. Rev. Mol. Cell Biol. 2002, 3, 430-440. [CrossRef]

17. Correia, S.; Poeta, P.; Hébraud, M.; Capelo, J.L.; Igrejas, G. Mechanisms of quinolone action and resistance: Where do we stand? J. Med. Microbiol. 2017, 66, 551-559. [CrossRef]

18. Blower, T.R.; Williamson, B.H.; Kerns, R.J.; Berger, J.M. Crystal structure and stability of gyrase-fluoroquinolone cleaved complexes from Mycobacterium tuberculosis. Proc. Natl. Acad. Sci. USA 2016, 113, 1706-1713. [CrossRef]

19. Aldred, K.J.; Kerns, R.J.; Osheroff, N. Mechanism of quinolone action and resistance. Biochemistry 2014, 53, 1565-1574. [CrossRef]

20. Takács-Novák, K.; Noszál, B.; Hermecz, I.; Keresztúri, G.; Podányi, B.; Szász, G. Protonation equilibria of quinolone antibacterials. J. Pharm. Sci. 1990, 79, 1023-1028. [CrossRef]

21. Regiel-Futyra, A.; Dabrowski, J.M.; Mazuryk, O.; Śpiewak, K.; Kyzioł, A.; Pucelik, B.; Brindell, M.; Stochel, G. Bioinorganic antimicrobial strategies in the resistance era. Coord. Chem. Rev. 2017, 351, 76-117. [CrossRef]

22. Debnath, A.; Mogha, N.K.; Masram, D.T. Metal complex of the first-generation quinolone antimicrobial drug nalidixic acid: Structure and its biological evaluation. Appl. Biochem. Biotechnol. 2015, 175, 2659-2667. [CrossRef] [PubMed]

23. Kouris, E.; Kalogiannis, S.; Perdih, F.; Turel, I.; Psomas, G. Cobalt(II) complexes of sparfloxacin: Characterization, structure, antimicrobial activity and interaction with DNA and albumins. J. Inorg. Biochem. 2016, 163, 18-27. [CrossRef] [PubMed]

24. Joshi, R.; Pandey, N.; Tilak, R.; Yadav, S.K.; Mishra, H.; Pokharia, S. New triorganotin(IV) complexes of quinolone antibacterial drug sparfloxacin: Synthesis, structural characterization, DFT studies and biological activity. Appl. Organomet. Chem. 2018, 32, e4324. [CrossRef]

25. El-Megharbel, S.M.; Hegab, M.S.; Manaaa, E.-S.A.; Al-Humaidi, J.Y.; Refat, M.S. Synthesis and physicochemical characterizations of coordination between palladium(II) metal ions with floroquinolone drugs as medicinal model against cancer cells: Novel metallopharmaceuticals. New J. Chem. 2018, 42, 9709-9719. [CrossRef] 
26. Boughougal, A.; Cherchali, F.Z.; Messai, A.; Attik, N.; Decoret, D.; Hologne, M.; Sanglar, C.; Pilet, G.; Tommasino, J.B.; Luneau, D. New model of metalloantibiotic: Synthesis, structure and biological activity of a zinc(II) mononuclear complex carrying two enrofloxacin and sulfadiazine antibiotics. New J. Chem. 2018, 42, 15346-15352. [CrossRef]

27. Elshafie, H.S.; Sakr, S.H.; Sadeek, S.A.; Camele, I. Biological Investigations and Spectroscopic Studies of New Moxifloxacin/Glycine-Metal Complexes. Chem. Biodivers. 2019, 16, e1800633. [CrossRef]

28. Feio, M.J.; Sousa, I.; Ferreira, M.; Cunha-Silva, L.; Saraiva, R.G.; Queirós, C.; Alexandre, J.G.; Claro, V.; Mendes, A.; Ortiz, R.; et al. Fluoroquinolone-metal complexes: A route to counteract bacterial resistance? J Inorg. Biochem. 2014, 138, 129-143. [CrossRef]

29. Dudev, T.; Chang, L.-Y.; Lim, C. Factors governing the substitution of $\mathrm{La}^{3+}$ for $\mathrm{Ca}^{2+}$ and $\mathrm{Mg}^{2+}$ in metalloproteins: A DFT/CDM study. J. Am. Chem. Soc. 2005, 127, 4091-4103. [CrossRef]

30. Hermann, P.; Kotek, J.; Kubíček, V.; Lukeš, I. Gadolinium(III) complexes as MRI contrast agents: Ligand design and properties of the complexes. Dalt. Trans. 2008, 3027-3047. [CrossRef]

31. Xiao, Y.-D.; Paudel, R.; Liu, J.; Cong, M.; Zhang, Z.-S.; Zhou, S.-K. MRI contrast agents: Classification and application (Review). Int. J. Mol. Med. 2016, 38, 1319-1326. [CrossRef] [PubMed]

32. Kim, H.-K.; Lee, G.H.; Chang, Y. Gadolinium as an MRI contrast agent. Future Med. Chem. 2018, 10, 639-661. [CrossRef] [PubMed]

33. Montgomery, C.P.; New, E.J.; Parker, D.; Peacock, R.D. Enantioselective regulation of a metal complex in reversible binding to serum albumin: dynamic helicity inversion signalled by circularly polarised luminescence. Chem. Commun. 2008, 4261-4263. [CrossRef]

34. Singh, G. Chemistry of Lanthanides and Actinides; Singh, G., Ed.; Discovery Publishing House: New Delhi, India, 2007; ISBN 81-8356-241-8.

35. Cotton, S. Coordination Chemistry of the Lanthanides. In Lanthanide and Actinide Chemistry; Wiley Online Books; John Wiley \& Sons, Ltd.: Hoboken, NJ, USA, 2006; pp. 35-60. ISBN 9780470010082.

36. Yakubovich, Y.Y.; Alekseev, V.G. Hydrolysis constants of tervalent lanthanum and lanthanide ions in $0.1 \mathrm{M}$ $\mathrm{KNO}_{3}$ solution. Russ. J. Inorg. Chem. 2012, 57, 911-915. [CrossRef]

37. Lawrance, G.A. Complexes and Commerce. In Introduction to Coordination Chemistry; Lawrance, G.A., Ed.; John Wiley \& Sons (Asia) Pte Ltd.: Chichester, UK, 2009; pp. 251-267. ISBN 978-0-470-51930-1.

38. Chen, Z.; Xu, H. Near-Infrared (NIR) Luminescence from Lanthanide(III) Complexes. In Rare Earth Coordination Chemistry; Huang, C., Ed.; John Wiley \& Sons (Asia) Pte Ltd.: Chichester, UK, 2010; pp. 473-527. ISBN 978-0-470-82485-6.

39. Yang, L.; Tao, D.; Yang, X.; Li, Y.; Guo, Y. Synthesis, characterization, and antibacterial activities of some rare Earth metal complexes of pipemidic acid. Chem. Pharm. Bull. (Tokyo) 2003, 51, 494-498. [CrossRef] [PubMed]

40. Návia, M.; Gálico, D.; Caires, F.; Luiz, J.; Nunes, R. Synthesis, thermal behavior, and spectroscopic study of the solid nalidixate of selected light trivalent lanthanides. J. Therm. Anal. Calorim. 2018, 132, 1717-1727. [CrossRef]

41. Li, J.-B.; Yang, P.; Gao, F.; Han, G.-Y.; Yu, K.-B. Novel Lanthanide Complexes of Ciprofloxacin: Synthesis, Characterization, Crystal Structure and in vitro Antibacterial Activity Studies. Chin. J. Chem. 2001, 19, 598-605. [CrossRef]

42. Čurman, D.; Živec, P.; Leban, I.; Turel, I.; Polishchuk, A.; Klika, K.D.; Karaseva, E.; Karasev, V. Spectral properties of $\mathrm{Eu}(\mathrm{III})$ compound with antibacterial agent ciprofloxacin (cfqH). Crystal structure of $\left[\mathrm{Eu}(\mathrm{cfqH})(\mathrm{cfq})\left(\mathrm{H}_{2} \mathrm{O}\right)_{4}\right] \mathrm{Cl}_{2} \cdot 4.55 \mathrm{H}_{2} \mathrm{O}$. Polyhedron 2008, 27, 1489-1496. [CrossRef]

43. Shaban, S.; El-Kemary, M.; Samir, G.; Elbaradei, H. Synthesis, characterization, antibacterial activities testing and the interaction of DNA with ciprofloxacin and its $\mathrm{La}(\mathrm{III})$-based complex. J. Chin. Adv. Mater. Soc. 2018, 6, 123-133. [CrossRef]

44. Wang, Y.-J.; Hu, R.-D.; Jiang, D.-H.; Zhang, P.-H.; Lin, Q.-Y.; Wang, Y.-Y. Synthesis, crystal structure, interaction with BSA and antibacterial activity of $\mathrm{La}$ (III) and Sm(III) complexes with enrofloxacin. J. Fluoresc. 2011, 21, 813-823. [CrossRef]

45. Tonghuan, L.; Lu, H.; Xi, P.; Liu, X.; Xu, Z.; Chen, F.; Zeng, Z. Synthesis, Characterization, and DNA-binding Properties of Ln(III) Complexes Containing Gatifloxacin. J. Biomol. Struct. Dyn. 2009, 26, 293-300.

46. Chen, M.; Zheng, Y.; Gao, J.; Wang, Q. Novel europium (III)-gatifloxacin complex structure with dual functionality for $\mathrm{pH}$ sensing and metal recognition in aqueous environment. Opt. Mater. 2016, 60, 1-5. [CrossRef] 
47. Sadeek, S.; El-Hamid, S.; Elaasser, M. Synthesis, characterization, antimicrobial and cytotoxicity studies of some transition metal complexes with gemifloxacin. Mon. Chem. Chem. Mon. 2015, 146, 1967-1982. [CrossRef]

48. Sadeek, S.; El-Hamid, S. Synthesis, spectroscopic, thermal analysis and in vitro biological properties of some new metal complexes with gemifloxacin and 1,10-phenanthroline. J. Therm. Anal. Calorim. 2015, 124, 547-562. [CrossRef]

49. Sakr, S.H.; Elshafie, H.S.; Camele, I.; Sadeek, S.A. Synthesis, Spectroscopic, and Biological Studies of Mixed Ligand Complexes of Gemifloxacin and Glycine with Zn(II), Sn(II), and Ce(III). Molecules 2018, 23, 1182. [CrossRef]

50. Sadeek, S.A.; El-Shwiniy, W.H. Preparation, structural characterization and biological studies of some new levofloxacin metal complexes. J. Iran. Chem. Soc. 2017, 14, 1711-1723. [CrossRef]

51. Sadeek, S.; El-Shwiniy, W.; El-Attar, M. Synthesis, characterization and antimicrobial investigation of some moxifloxacin metal complexes. Spectrochim. Acta A Mol. Biomol. Spectrosc. 2011, 84, 99-110. [CrossRef]

52. Li, S.; Wang, Y.; Lin, Q.; Liu, W.; Ding, J.; Wang, Y. Synthesis, crystal structures of novel complexes of rare earth with norfloxacin, interaction with DNA and BSA. J. Rare Earths 2012, 30, 460-466. [CrossRef]

53. Refat, M.; El-Hawary, W.; Mohamed, M. Study of the chemical chelates and anti-microbial effect of some metal ions in nanostructural form on the efficiency of antibiotic therapy "norfloxacin drug". J. Mol. Struct. 2012, 1013, 45-54. [CrossRef]

54. Shaban, S.; El-Kemary, M.; Samir, G.; El-Baradei, G.; Puchta, R. Norfloxacin La(III)-based complex: Synthesis, characterization and DNA binding studies. J. Coord. Chem. 2015, 68, 3247-3258. [CrossRef]

55. Xu, M.; Chen, F.-J.; Huang, L.; Xi, P.; Zeng, Z. Binding of rare earth metal complexes with an ofloxacin derivative to bovine serum albumin and its effect on the conformation of protein. J. Lumin. 2011, 131, 1557-1565. [CrossRef]

56. Xu, M.; Ma, Z.R.; Huang, L.; Chen, F.J.; Zeng, Z. Spectroscopic studies on the interaction between $\operatorname{Pr}(\mathrm{III})$ complex of an ofloxacin derivative and bovine serum albumin or DNA. Spectrochim. Acta A Mol. Biomol. Spectrosc. 2011, 78, 503-511. [CrossRef] [PubMed]

57. El-Gamel, N.E.A.; Zayed, M.A. Synthesis, structural characterization and antimicrobial activity evaluation of metal complexes of sparfloxacin. Spectrochim. Acta A Mol. Biomol. Spectrosc. 2011, 82, 414-423. [CrossRef] [PubMed]

58. Xu, M.; Zhang, Y.; Xu, Z.; Zeng, Z. Crystal structure, biological studies of water-soluble rare earth metal complexes with an ofloxacin derivative. Inorg. Chim. Acta 2012, 384, 324-332. [CrossRef]

59. Andreu, V.; Blasco, C.; Pico, Y. Analytical strategies to determine quinolone residues in food and the environment. TrAC Trends Anal. Chem. 2007, 26, 534-556. [CrossRef]

60. Prabhakaran, D.; Sukul, P.; Lamshoft, M.; Maheswari, M.A.; Zuhlke, S.; Spiteller, M. Photolysis of difloxacin and sarafloxacin in aqueous systems. Chemosphere 2009, 77, 739-746. [CrossRef]

61. Kotzerke, A.; Hammesfahr, U.; Kleineidam, K.; Lamshöft, M.; Sören, T.-B.; Schloter, M.; Wilke, B.-M. Influence of difloxacin-contaminated manure on microbial community structure and function in soils. Biol. Fertil. Soils 2010, 47, 177-186. [CrossRef]

62. Lopez de Alda, M. Environmental Behavior and Analysis of Veterinary and Human Drugs in Soils, Sediments and Sludge. TrAC Trends Anal. Chem. 2003, 22, 340-351.

63. Kummerer, K. Drugs in the environment: emission of drugs, diagnostic aids and disinfectants into wastewater by hospitals in relation to other sources-A review. Chemosphere 2001, 45, 957-969. [CrossRef]

64. Tamtam, F.; Mercier, F.; Le Bot, B.; Eurin, J.; Tuc Dinh, Q.; Clement, M.; Chevreuil, M. Occurrence and fate of antibiotics in the Seine River in various hydrological conditions. Sci. Total Environ. 2008, 393, 84-95. [CrossRef]

65. Li, Y.L.; Hao, X.L.; Ji, B.Q.; Xu, C.L.; Chen, W.; Shen, C.Y.; Ding, T. Rapid determination of 19 quinolone residues in spiked fish and pig muscle by high-performance liquid chromatography (HPLC) tandem mass spectrometry. Food Addit. Contam. Part A Chem. Anal. Control Exp. Risk Assess. 2009, 26, 306-313. [CrossRef] [PubMed]

66. Espinosa-Mansilla, A.; de la Pena, A.M.; Gomez, D.G.; Salinas, F. HPLC determination of enoxacin, ciprofloxacin, norfloxacin and ofloxacin with photoinduced fluorimetric (PIF) detection and multiemission scanning: application to urine and serum. J. Chromatogr. B Anal. Technol. Biomed. Life Sci. 2005, 822, 185-193. [CrossRef] [PubMed] 
67. Watabe, S.; Yokoyama, Y.; Nakazawa, K.; Shinozaki, K.; Hiraoka, R.; Takeshita, K.; Suzuki, Y. Simultaneous measurement of pazufloxacin, ciprofloxacin, and levofloxacin in human serum by high-performance liquid chromatography with fluorescence detection. J. Chromatogr. B Anal. Technol. Biomed. Life Sci. 2010, 878, 1555-1561. [CrossRef] [PubMed]

68. Horstkotter, C.; Blaschke, G. Stereoselective determination of ofloxacin and its metabolites in human urine by capillary electrophoresis using laser-induced fluorescence detection. J. Chromatogr. B Biomed. Sci. Appl. 2001, 754, 169-178. [CrossRef]

69. Hernandez, M.; Aguilar, C.; Borrull, F.; Calull, M. Determination of ciprofloxacin, enrofloxacin and flumequine in pig plasma samples by capillary isotachophoresis-Capillary zone electrophoresis. J. Chromatogr. B Anal. Technol. Biomed. Life Sci. 2002, 772, 163-172. [CrossRef]

70. D'Agostino, P.A.; Hancock, J.R.; Chenier, C.L.; Lepage, C.R.J. Liquid chromatography electrospray tandem mass spectrometric and desorption electrospray ionization tandem mass spectrometric analysis of chemical warfare agents in office media typically collected during a forensic investigation. J. Chromatogr. A 2006, 1110, 86-94. [CrossRef]

71. Ghoneim, M.M.; Radi, A.; Beltagi, A.M. Determination of Norfloxacin by square-wave adsorptive voltammetry on a glassy carbon electrode. J. Pharm. Biomed. Anal. 2001, 25, 205-210. [CrossRef]

72. Tamer, A. Adsorptive stripping voltammetric determination of ofloxacin. Anal. Chim. Acta 1990, 231, $129-131$. [CrossRef]

73. Jaber, A.M.Y.; Lounici, A. Polarographic behaviour and determination of norfloxacin in tablets. Anal. Chim. Acta 1994, 291, 53-64. [CrossRef]

74. Kilic, E.; Koseoglu, F; Akay, M.A. The non-aqueous titrimetric assay of selected antibiotics using tetra-N-butylammonium hydroxide as titrant. J. Pharm. Biomed. Anal. 1994, 12, 347-352. [CrossRef]

75. El-Brashy, A.M.; El-Sayed Metwally, M.; El-Sepai, F.A. Spectrophotometric determination of some fluoroquinolone antibacterials by binary complex formation with xanthene dyes. Farmaco 2004, 59, 809-817. [CrossRef] [PubMed]

76. Mostafa, S.; El-Sadek, M.; Alla, E.A. Spectrophotometric determination of ciprofloxacin, enrofloxacin and pefloxacin through charge transfer complex formation. J. Pharm. Biomed. Anal. 2002, 27, 133-142. [CrossRef]

77. Kaur, K.; Singh, B.; Malik, A. Chemiluminescence and Spectrofluorimetric Methods for Determination of Fluoroquinolones: A Review. Anal. Lett. 2011, 44, 1602-1639. [CrossRef]

78. Sun, C.; Ping, H.; Zhang, M.; Li, H.; Guan, F. Spectroscopic studies on the lanthanide sensitized luminescence and chemiluminescence properties of fluoroquinolone with different structure. Spectrochim. Acta A Mol. Biomol. Spectrosc. 2011, 82, 375-382. [CrossRef] [PubMed]

79. Zhang, H.; Fan, R.; Wang, P.; Wang, X.; Gao, S.; Dong, Y.; Wang, Y.; Yang, Y. Structure variations of a series of lanthanide complexes constructed from quinoline carboxylate ligands: Photoluminescent properties and PMMA matrix doping. RSC Adv. 2015, 5, 38254-38263. [CrossRef]

80. Georges, J. Lanthanide-sensitized luminescence and applications to the determination of organic analytes. A review. Analyst 1993, 118, 1481-1486. [CrossRef]

81. Gómez-Hens, A.; Aguilar-Caballos, M. Terbium-sensitized luminescence: A selective and versatile analytical approach. TrAC Trends Anal. Chem. 2002, 21, 131-141. [CrossRef]

82. Junker, A.K.R.; Sørensen, T.J. Illuminating the Intermolecular vs. Intramolecular Excited State Energy Transfer Quenching by Europium(III) Ions. Eur. J. Inorg. Chem. 2019, 2019, 1201-1206. [CrossRef]

83. Izosimov, I.N. Time-resolved Laser-induced Luminescence/Chemiluminescence Laser Spectroscopy and Detection of Actinides/Lanthanides. In Environmental Radiochemical Analysis VI; The Royal Society of Chemistry: London, UK, 2020; pp. 115-130. ISBN 978-1-78801-735-0.

84. Singha, S.; Ahn, K.H. Detection of Ciprofloxacin in Urine through Sensitized Lanthanide Luminescence. Sensors 2016, 16, 2065. [CrossRef]

85. Veiopoulou, C.J.; Ioannou, P.C.; Lianidou, E.S. Application of terbium sensitized fluorescence for the determination of fluoroquinolone antibiotics pefloxacin, ciprofloxacin and norfloxacin in serum. J. Pharm. Biomed. Anal. 1997, 15, 1839-1844. [CrossRef]

86. Rodríguez-Díaz, R.; Aguilar-Caballos, M.; Gómez-Hens, A. Sensitive Determination of Fluoroquinolone Antibiotics in Milk Samples Using Time-Resolved Methodology. Anal. Lett. 2011, 37, 1163-1175. [CrossRef] 
87. Ocana, J.A.; Callejon, M.; Barragan, F.J. Terbium-sensitized luminescence determination of levofloxacin in tablets and human urine and serum. Analyst 2000, 125, 1851-1854. [CrossRef] [PubMed]

88. Ocana, J.A.; Callejon, M.; Barragan, F.J. Application of terbium-sensitized luminescence for the determination of grepafloxacin in human urine and serum. J. Pharm. Sci. 2001, 90, 1553-1557. [CrossRef] [PubMed]

89. Ocaña, J.A.; Barragán, F.J.; Callejón, M. Fluorescence and terbium-sensitised luminescence determination of garenoxacin in human urine and serum. Talanta 2004, 63, 691-697. [CrossRef] [PubMed]

90. Shtykov, S.N. Chemical Analysis in Nanoreactors: Main Concepts and Applications. J. Anal. Chem. 2002, 57, 859-868. [CrossRef]

91. Shtykov, S.N.; Smirnova, T.D.; Bylinkin, Y.G.; Kalashnikova, N.V.; Zhemerichkin, D.A. Determination of ciprofloxacin and enrofloxacin by the sensitized fluorescence of europium in the presence of the second ligand and micelles of anionic surfactants. J. Anal. Chem. 2007, 62, 136-140. [CrossRef]

92. Tan, H.; Zhang, L.; Ma, C.; Song, Y.; Xu, F.; Chen, S.; Wang, L. Terbium-based coordination polymer nanoparticles for detection of ciprofloxacin in tablets and biological fluids. ACS Appl. Mater. Interfaces 2013, 5, 11791-11796. [CrossRef]

93. Xu, X.; Feng, L.; Li, J.; Yuan, P.; Feng, J.; Wei, L.; Cheng, X. Rapid screening detection of fluoroquinolone residues in milk based on turn-on fluorescence of terbium coordination polymer nanosheets. Chin. Chem. Lett. 2018, 30, 549-552. [CrossRef]

94. Liu, B.; Huang, Y.; Shen, Q.; Zhu, X.; Hao, Y.; Qu, P.; Xu, M. Turn-on fluorescence detection of ciprofloxacin in tablets based on lanthanide coordination polymer nanoparticles. RSC Adv. 2016, 6, 100743-100747. [CrossRef]

95. Kamruzzaman, M.; Alam, A.-M.; Lee, S.; Suh, Y.; Kim, Y.H.; Kim, G.M.; Kim, H. Method for determination of fluoroquinolones based on the plasmonic interaction between their fluorescent terbium complexes and silver nanoparticles. Microchim. Acta 2011, 174, 353-360. [CrossRef]

96. Kaur, B.; Kumar, R.; Chand, S.; Singh, K.; Malik, A.K. Determination of norfloxacin in urine and pharmaceutical samples using terbium doped zinc sulphide nanomaterials-sensitized fluorescence method. Spectrochim. Acta A Mol. Biomol. Spectrosc. 2019, 214, 261-268. [CrossRef] [PubMed]

97. Yanez-Jacome, G.S.; Aguilar-Caballos, M.P.; Gomez-Hens, A. Luminescent determination of quinolones in milk samples by liquid chromatography/post-column derivatization with terbium oxide nanoparticles. J. Chromatogr. A 2015, 1405, 126-132. [CrossRef] [PubMed]

98. Ding, F.; Zhao, H.; Jin, L.; Zheng, D. Study of the influence of silver nanoparticles on the second-order scattering and the fluorescence of the complexes of $\mathrm{Tb}(\mathrm{III})$ with quinolones and determination of the quinolones. Anal. Chim. Acta 2006, 566, 136-143. [CrossRef]

99. Lee, S.H.; Wabaidur, S.M.; Alothman, Z.A.; Alam, S.M. Gold nanoparticles-based fluorescence enhancement of the terbium-levofloxacin system and its application in pharmaceutical preparations. Luminescence 2011, 26, 768-773. [CrossRef]

100. Wei, L.; Cheng, X.; Lin, J.-M.; Cai, H.; Huang, F. Chemiluminescence mechanisms of cerium-norfloxacin and its application in urine analysis. Chem. Pap. 2009, 63, 358-365. [CrossRef]

101. Zhu, Y.; Shu, G.; Yang, Y.; Dong, Q.; Zou, L. Synthesis and electrochemiluminescence properties of a new ternary terbium complex and its application for the determination of norfloxacin. J. Electroanal. Chem. 2014, 727, 113-119. [CrossRef]

102. Jeon, C.; Khan, M.; Lee, S.; Karim, M.; Lee, H.; Suh, Y.; Alam, S.; Chung, H. Optical Flow-Through Sensor for the Determination of Norfloxacin Based on Emission of $\mathrm{KMnO}_{4}-\mathrm{Na}_{2} \mathrm{SO}_{3}-\mathrm{Tb}^{3+}$ System. J. Fluoresc. 2008, 18, 843-851. [CrossRef]

103. Chen, L.; Wang, X.; Zhao, H.; Wang, K.; Jin, L. Flow-injection chemiluminescence determination of ofloxacin using the $\mathrm{Ru}(\mathrm{bpy})_{2}(\mathrm{CIP})^{2+}$-Ce(IV) system and its application. Luminescence 2008, 23, 309-315. [CrossRef]

104. Sun, H.; Li, L.; Wu, Y. Dysprosium-sensitized chemiluminescence reactions: Their mechanism and application to the determination of synthetic quinolone antibiotics. J. Anal. Chem. 2011, 66, 720. [CrossRef]

105. Ocana-Gonzalez, J.A.; Ramos-Payan, M.; Fernandez-Torres, R.; Callejon-Mochon, M.; Bello-Lopez, M.A. Hollow-fiber liquid-phase microextraction for the direct determination of flumequine in urban wastewaters by flow-injection analysis with terbium-sensitized chemiluminescence. J. Sep. Sci. 2014, 37, 2738-2744. [CrossRef] 
106. Chen, S.; Ding, F.; Liu, Y.; Zhao, H. Electrochemiluminescence of terbium (III)-two fluoroquinolones-sodium sulfite system in aqueous solution. Spectrochim. Acta A Mol. Biomol. Spectrosc. 2006, 64, 130-135. [CrossRef]

107. Murillo Pulgarín, J.A.; Alañón Molina, A.; Jiménez García, E. Simplex optimization of the variables influencing the determination of pefloxacin by time-resolved chemiluminescence. Spectrochim. Acta Part A Mol. Biomol. Spectrosc. 2018, 193, 117-124. [CrossRef] [PubMed]

108. Lozano, V.A.; Tauler, R.; Ibanez, G.A.; Olivieri, A.C. Standard addition analysis of fluoroquinolones in human serum in the presence of the interferent salicylate using lanthanide-sensitized excitation-time decay luminescence data and multivariate curve resolution. Talanta 2009, 77, 1715-1723. [CrossRef] [PubMed]

109. Sun, H.; Li, L.; Chen, X. Investigation on sensitized chemiluminescence systems and their mechanism for five fluoroquinolones. Anal. Chim. Acta 2006, 576, 192-199. [CrossRef] [PubMed]

110. Ocaña, J.A.; Barragán, F.J.; Callejón, M.; De la Rosa, F. Application of Lanthanide-Sensitised Chemiluminescence to the Determination of Levofloxacin, Moxifloxacin and Trovafloxacin in Tablets. Microchim. Acta 2004, 144, 207-213. [CrossRef]

111. Wang, L.; Guo, C.; Chu, Z.; Jiang, W. Luminescence enhancement effect for the determination of balofloxacin with balofloxacin-europium (III)-sodium dodecylbenzene sulfonate system. J. Lumin. 2009, 129, 90-94. [CrossRef]

112. Cai, H.; Zhao, F.; Si, H.; Zhang, S.; Wang, C.; Qi, P. Highly sensitive luminescence assessment of bile acid using a balofloxacin-europium(III) probe in micellar medium. Bull. Korean Chem. Soc. 2012, 33, 4145-4149. [CrossRef]

113. Zhao, F.; Qi, Y.; Xiong, W. Chemiluminescence determination of balofloxacin based on europium (III)-sensitized $\mathrm{KBrO}_{3}-\mathrm{Na}_{2} \mathrm{~S}_{2} \mathrm{O}_{4}$ reaction in micellar medium. Bull. Korean Chem. Soc. 2012, 33, $204-208$. [CrossRef]

114. Qi, Y.; Zhao, F.; Xie, X.; Xu, X.; Ma, Z. Study on the cofluorescence effect of europium (III)-yttrium (III)-balofloxacin-sodium dodecyl sulfate system and its analytical application. Spectrosc. Lett. 2015, 48, 311-316. [CrossRef]

115. Hernández-Arteseros, J.A.; Compañó, R.; Ferrer, R.; Prat, M.D. Application of principal component regression to luminescence data for the screening of ciprofloxacin and enrofloxacin in animal tissues. Analyst 2000, 125, 1155-1158. [CrossRef]

116. Rieutord, A.; Vazquez, L.; Soursac, M.; Prognon, P.; Blais, J.; Bourget, P.; Mahuzier, G. Fluoroquinolones as sensitizers of lanthanide fluorescence: Application to the liquid chromatographic determination of ciprofloxacin using terbium. Anal. Chim. Acta 1994, 290, 215-225. [CrossRef]

117. Sierra-Rodero, M.; Fernández-Romero, J.M.; Gómez-Hens, A. Determination of fluoroquinolone antibiotics by microchip capillary electrophoresis along with time-resolved sensitized luminescence of their terbium(III) complexes. Microchim. Acta 2014, 181, 1897-1904. [CrossRef]

118. Rodríguez-Díaz, R.C.; Aguilar-Caballos, M.; Gómez-Hens, A. Simultaneous determination of ciprofloxacin and tetracycline in biological fluids based on dual-lanthanide sensitised luminescence using dry reagent chemical technology. Anal. Chim. Acta 2003, 494, 55-62. [CrossRef]

119. Lian, N.; Zhao, H.; Sun, C.; Chen, S.; Lu, Y.; Jin, L. A study on terbium sensitized chemiluminescence of ciprofloxacin and its application. Microchem. J. 2003, 74, 223-230. [CrossRef]

120. Liu, J.; Chen, K.; Li, B.; Zhu, Y. A novel method to determine ciprofloxacin by enhanced electrochemiluminescence of $\mathrm{Tb}(\mathrm{bpy})_{2}{ }^{3+}-\mathrm{K}_{2} \mathrm{~S}_{2} \mathrm{O}_{8}$ system in aqueous solution. Anal. Methods 2012, 4, 2355-2360. [CrossRef]

121. Rizk, M.; Habib, I.H.I.; Mohamed, D.; Mowaka, S. Lanthanide-DNA probe for spectrofluorimetric determination of some 6- fluoroquinolones in eye-ear pharmaceutical preparations. Microchem. J. 2019, 150, 104138. [CrossRef]

122. Attia, M.; Essawy, A.; Youssef, A. Europium-sensitized and simultaneous pH-assisted spectrofluorimetric assessment of ciprofloxacin, norfloxacin and gatifloxacin in pharmaceutical and serum samples. J. Photochem. Photobiol. A Chem. 2012, 236, 26-34. [CrossRef]

123. Kamruzzaman, M.; Alam, A.; Kim, K.M.; Lee, S.H.; Suh, Y.S.; Kim, Y.H.; Kim, S.H.; Oh, S.H. Enhanced Luminescence of Lanthanide Complexes by Silver Nanoparticles for Ciprofloxacin Determination. J. Nanosci. Nanotechnol. 2012, 12, 6125-6130. [CrossRef] 
124. Wang, B.; Yan, B. A turn-on fluorescence probe $\mathrm{Eu}^{3+}$ functionalized Ga-MOF integrated with logic gate operation for detecting ppm-level ciprofloxacin (CIP) in urine. Talanta 2020, 208, 120438. [CrossRef]

125. Sun, H.; Wu, Y.; Li, L. Dysprosium-sensitized chemiluminescence system for the determination of enoxacin in pharmaceutical preparations and biological fluids with flow-injection sampling. Drug Test. Anal. 2009, 1, 128-134. [CrossRef]

126. Yi, L.; Zhao, H.; Chen, S.; Jin, L.; Zheng, D.; Wu, Z. Flow-injection analysis of two fluoquinolones by the sensitizing effect of terbium(III) on chemiluminescence of the potassium permanganate-sodium sulfite system. Talanta 2003, 61, 403-409. [CrossRef]

127. Karim, M.M.; Lee, S.H. Determination of enoxacin using Tb composite nanoparticles sensitized luminescence method. J. Fluoresc. 2008, 18, 827-833. [CrossRef] [PubMed]

128. Attia, M.S.; Sabry, D.; Youssef, A.O. Enrofloxacin Assessment by the Enhancement of the Red Emission of $\mathrm{Eu}^{3+}$ Optical Sensor. Anal. Chem. Lett. 2014, 4, 65-72. [CrossRef]

129. Zdunek, J.; Benito-Peña, E.; Linares, A.; Falcimaigne-Cordin, A.; Orellana, G.; Haupt, K.; Moreno-Bondi, M.C. Surface-imprinted nanofilaments for europium-amplified luminescent detection of fluoroquinolone antibiotics. Chem. A Eur. J. 2013, 19, 10209-10216. [CrossRef]

130. Ershadi, S.; Jouyban, A.; Shayanfar, A. Determination of Enrofloxacin in Milk Samples Using Silver Nanoparticle Enhanced Terbium-Sensitized Fluorescence Method. Food Anal. Methods 2017, 10, 3607-3614. [CrossRef]

131. Kaczmarek, M.; Staninski, K.; Stodolny, M. Oxidation of certain fluoroquinolones using the chemical sources of reactive oxygen species in the presence of $\mathrm{Tb}(\mathrm{III})$ ions and analytical application of these systems. J. Lumin. 2019, 215, 116654. [CrossRef]

132. Schneider, M.J.; Yun, L.; Lehotay, S.J. Terbium-sensitised luminescence screening method for fluoroquinolones in beef serum. Food Addit. Contam. Part A Chem. Anal. Control Exp. Risk Assess. 2013, 30, 666-669. [CrossRef]

133. Sun, H.; Li, L. Flow-Injection Chemiluminescence Determination of Fleroxacin in Pharmaceutical Preparations and Human Urine. J. Chromatogr. Sep. Tech. 2010, 1, 104. [CrossRef]

134. Liu, T.Y.; Qu, X.L.; Yan, B. A highly sensitive and selective "turn-on" fluorescent probe for detection of fleroxacin in human serum and urine based on a lanthanide functionalized metal-organic framework. Dalt. Trans. 2019, 48, 17945-17952. [CrossRef]

135. Yan, W.; Tieli, Z.; Huichun, Z.; Linpei, J. Photochemical fluorescence enhancement of terbium-fleroxacin system and determination of fleroxacin. Anal. Lett. 2000, 33, 3303-3314. [CrossRef]

136. Rodriguez-Diaz, R.C.; Fernandez-Romero, J.M.; Aguilar-Caballos, M.P.; Gomez-Hens, A. Chromatographic determination of flumequine in food samples by post-column derivatisation with terbium(III). Anal. Chim. Acta 2006, 578, 220-226. [CrossRef] [PubMed]

137. Smirnova, T.D.; Shtykov, S.N.; Nevryueva, N.V.; Zhemerichkin, D.A.; Parashchenko, I.I. Fluorimetric assay of flumequine using sensitized terbium fluorescence in organized media. Pharm. Chem. J. 2011, 44, 635-638. [CrossRef]

138. Castillo-García, M.L.; Aguilar-Caballos, M.P.; Gómez-Hens, A. A europium- and terbium-coated magnetic nanocomposite as sorbent in dispersive solid phase extraction coupled with ultra-high performance liquid chromatography for antibiotic determination in meat samples. J. Chromatogr. A 2015, 1425, 73-80. [CrossRef] [PubMed]

139. Guo, C.; Dong, P.; Chu, Z.; Wang, L.; Jiang, W. Rapid determination of gatifloxacin in biological samples and pharmaceutical products using europium-sensitized fluorescence spectrophotometry. Luminescence 2008, 23, 7-13. [CrossRef] [PubMed]

140. Attia, M.; Youssef, A.; Essawy, A.; Abdel-Mottaleb, M. A highly luminescent complexes of Eu(III) and Tb(III) with norfloxacin and gatifloxacin doped in sol-gel matrix: A comparable approach of using silica doped $\mathrm{Tb}(\mathrm{III})$ and $\mathrm{Eu}(\mathrm{III})$ as optical sensor. J. Lumin. 2012, 132, 2741-2746. [CrossRef]

141. Ocaña, J.A.; Callejón, M.; Barragán, F.J.; De la Rosa, F.F. Lanthanide sensitized chemiluminescence determination of grepafloxacin in tablets and human urine. Anal. Chim. Acta 2003, 482, 105-113. [CrossRef]

142. El-Hamshary, M.S.; Fouad, M.A.; Hanafi, R.S.; Al-Easa, H.S.; El-Moghazy, S.M. Screening and optimization of samarium-assisted complexation for the determination of norfloxacin, levofloxacin and lomefloxacin in their corresponding dosage forms employing spectrofluorimetry. Spectrochim. Acta A Mol. Biomol. Spectrosc. 2019, 206, 578-587. [CrossRef] 
143. Wang, J.M.; Lian, X.; Yan, B. Eu ${ }^{3+}$-Functionalized Covalent Organic Framework Hybrid Material as a Sensitive Turn-On Fluorescent Switch for Levofloxacin Monitoring in Serum and Urine. Inorg. Chem. 2019, 58, 9956-9963. [CrossRef]

144. Wang, L.; Liu, J.; Wang, Z.; Wang, Y. Fluorescence resonance energy transfer between cerium ion(III) and levofloxacin in micellar solution and its analytical application to the determination of levofloxacin. Spectrosc. Lett. 2019, 52, 313-320. [CrossRef]

145. Nie, L.H.; Zhao, H.C.; Wang, X.; Yi, L.; Lu, Y.; Jin, L.P.; Ma, H.M. Determination of lomefloxacin by terbium sensitized chemiluminescence method. Anal. Bioanal. Chem. 2002, 374, 1187-1190. [CrossRef]

146. Rodriguez-Diaz, R.C.; Fernandez-Romero, J.M.; Aguilar-Caballos, M.P.; Gomez-Hens, A. Determination of fluoroquinolones in milk samples by postcolumn derivatization liquid chromatography with luminescence detection. J. Agric. Food Chem. 2006, 54, 9670-9676. [CrossRef]

147. Beltyukova, S.; Teslyuk, O.; Egorova, A.; Tselik, E. Solid-Phase Luminescence Determination of Ciprofloxacin and Norfloxacin in Biological Fluids. J. Fluoresc. 2002, 12, 269-272. [CrossRef]

148. Chen, S.L.; Liu, Y.; Zhao, H.C.; Jin, L.P.; Zhang, Z.L.; Zheng, Y.Z. Determination of norfloxacin using a terbium-sensitized electrogenerated chemiluminescence method. Luminescence 2006, 21, 20-25. [CrossRef] [PubMed]

149. Bel'tyukova, S.V.; Malinka, E.V.; Liventsova, E.O. Determination of ofloxacin and norfloxacin in wastewaters of pharmaceutical enterprises using sensitized luminescence of $\mathrm{Tb}(\mathrm{III})$ complexes. J. Water Chem. Technol. 2008, 30, 38-41.

150. Llorent-Martínez, E.; Garcia-Reyes, J.F.; Ortega-Barrales, P.; Molina-Díaz, A. Terbium-sensitized luminescence optosensor for the determination of norfloxacin in biological fluids. Anal. Chim. Acta 2005, 532, 159-164. [CrossRef]

151. Hu, G.; Sheng, W.; Zhang, Y.; Wu, X.; Wang, S. A novel and sensitive fluorescence immunoassay for the detection of fluoroquinolones in animal-derived foods using upconversion nanoparticles as labels. Anal. Bioanal. Chem. 2015, 407, 8487-8496. [CrossRef]

152. Zhang, X.; Ouyang, J.; Zhai, S.; Huang, G.; Zhao, H. Flow-injection with enhanced chemiluminescence detection of ofloxacin in human plasma. Luminescence 2005, 20, 362-369. [CrossRef]

153. Attia, M.S.; Essawy, A.A.; Youssef, A.O.; Mostafa, M.S. Determination of ofloxacin using a highly selective photo probe based on the enhancement of the luminescence intensity of $\mathrm{Eu}^{3+}$-ofloxacin complex in pharmaceutical and serum samples. J. Fluoresc. 2012, 22, 557-564. [CrossRef]

154. Llorent-Martinez, E.J.; Ortega-Barrales, P.; Molina-Diaz, A.; Ruiz-Medina, A. Implementation of terbium-sensitized luminescence in sequential-injection analysis for automatic analysis of orbifloxacin. Anal. Bioanal. Chem. 2008, 392, 1397-1403. [CrossRef]

155. Chen, S.; Ma, H.; Zhao, H.; Feng, R.; Jin, L. Terbium-sensitized fluorescence method for the determination of pazufloxacin mesilate and its application. Anal. Sci. 2004, 20, 1075-1078. [CrossRef]

156. Wang, X.-L.; Chen, S.-L.; Zhao, H.-C.; Jin, L.-P.; Li, X. Europium Sensitized Chemiluminescence Determination of Pazufloxacin Mesylate in Urine and Serum. Anal. Lett. 2005, 38, 971-979. [CrossRef]

157. Yang, C.; Zhang, Z.; Chen, S.; Yang, F. Molecularly imprinted on-line solid-phase extraction combined with chemiluminescence for the determination of pazufloxacin mesilate. Microchim. Acta 2007, 159, $299-304$. [CrossRef]

158. Li, A.; Song, Z. Study of silver nanoparticles sensitized fluorescence and second-order scattering of terbium(III)-pefloxacin mesylate complex and determination of pefloxacin mesylate. Sci. World J. 2014, 2014, 742935. [CrossRef] [PubMed]

159. Llorent-Martinez, E.J.; Ortega-Barrales, P.; Molina-Diaz, A. Multicommuted optosensor for the determination of pipemidic acid in biological fluids. Anal. Biochem. 2005, 347, 330-332. [CrossRef]

160. Wang, X.L.; Li, A.Y.; Zhao, H.C.; Jin, L.P. A lanthanide sensitized chemiluminescence method of flow-injection for the determination of ulifloxacin and prulifloxacin. J. Anal. Chem. 2009, 64, 75-81. [CrossRef]

161. Yu, F.; Li, L.; Chen, F.; Liu, W. Terbium sensitized chemiluminescence of potassium permanganate-sodium thiosulfateprulifloxacin system and its application. Anal. Lett. 2010, 43, 357-366. [CrossRef]

162. Dong, P.; Xu, N.; Fu, B.; Wang, L. Rapid europium-sensitized fluorescent determination of ulifloxacin, the active metabolite of prulifloxacin, in human serum and urine. J. Pharm. Anal. 2011, 1, 46-50. [CrossRef] 
163. Davydov, N.; Zairov, R.; Mustafina, A.; Syakayev, V.; Tatarinov, D.; Mironov, V.; Eremin, S.; Konovalov, A.; Mustafin, M. Determination of fluoroquinolone antibiotics through the fluorescent response of Eu(III) based nanoparticles fabricated by layer-by-layer technique. Anal. Chim. Acta 2013, 784, 65-71. [CrossRef]

164. Wang, N.-X.; Wang, L.; Jiang, W.; Ren, Y.-Z.; Si, Z.-K.; Qiu, X.-X.; Du, G.-Y.; Qi, P. Determination of neodymium, holmium and erbium in mixed rare earths by norfloxacin. Fresenius' J. Anal. Chem. 1998, 361, 821-824. [CrossRef]

165. Guo, C.; Lang, A.; Wang, L.; Jiang, W. The co-luminescence effect of a europium (III)-lanthanum (III)-gatifloxacin-sodium dodecylbenzene sulfonate system and its application for the determination of trace amount of europium (III). J. Lumin. 2010, 130, 591-597. [CrossRef]

166. Turel, M.; Duerkop, A.; Yegorova, A.; Scripinets, Y.; Lobnik, A.; Samec, N. Detection of nanomolar concentrations of copper(II) with a Tb-quinoline-2-one probe using luminescence quenching or luminescence decay time. Anal. Chim. Acta 2009, 644, 53-60. [CrossRef] [PubMed]

167. Abbasi, Y.; Ali, A.A.; Khan, M.; Saeed, M.; Naeem, K. Liquid-liquid extraction of scandium with nalidixic acid in dichloromethane. J. Radioanal. Nucl. Chem. 2012, 292, 277-283. [CrossRef]

168. Turel, M.; Duerkop, A.; Yegorova, A.; Karasyov, A.; Scripinets, Y.; Lobnik, A. Microtiterplate phosphate assay based on luminescence quenching of a terbium complex amenable to decay time detection. Anal. Chim. Acta 2010, 675, 42-48. [CrossRef] [PubMed]

169. Le Pecq, J.B.; Paoletti, C. A new fluorometric method for RNA and DNA determination. Anal. Biochem. 1966, 17, 100-107. [CrossRef]

170. Rye, H.S.; Yue, S.; Wemmer, D.E.; Quesada, M.A.; Haugland, R.P.; Mathies, R.A.; Glazer, A.N. Stable fluorescent complexes of double-stranded DNA with bis-intercalating asymmetric cyanine dyes: Properties and applications. Nucleic Acids Res. 1992, 20, 2803-2812. [CrossRef] [PubMed]

171. Wu, T.; Fang, B.; Chang, L.; Liu, M.; Chen, F. Sensitive determination of DNA based on the interaction between prulifloxacin-terbium(III) complex and DNA. Luminescence 2013, 28, 894-899. [CrossRef]

172. Yegorova, A.; Karasyov, A.; Dürkop, A.; Ukrainets, I.; Antonovich, V. New luminescent terbium complex for the determination of DNA. Spectrochim. Acta A Mol. Biomol. Spectrosc. 2005, 61, 109-116. [CrossRef]

173. Jenkins, Y.; Friedman, A.E.; Turro, N.J.; Barton, J.K. Characterization of dipyridophenazine complexes of ruthenium(II): The light switch effect as a function of nucleic acid sequence and conformation. Biochemistry 1992, 31, 10809-10816. [CrossRef]

174. Wang, L.; Guo, C.; Fu, B.; Wang, L. Fluorescence determination of DNA using the gatifloxacin-europium(III) complex. J. Agric. Food Chem. 2011, 59, 1607-1611. [CrossRef]

175. Yegorova, A.V.; Scripinets, Y.V.; Duerkop, A.; Karasyov, A.A.; Antonovich, V.P.; Wolfbeis, O.S. Sensitive luminescent determination of DNA using the terbium(III)-difloxacin complex. Anal. Chim. Acta 2007, 584, 260-267. [CrossRef]

176. Chen, Y.; Chi, Y.; Wen, H.; Lu, Z. Sensitized luminescent terbium nanoparticles: preparation and time-resolved fluorescence assay for DNA. Anal. Chem. 2007, 79, 960-965. [CrossRef] [PubMed]

177. Krasnoperov, L.N.; Marras, S.A.E.; Kozlov, M.; Wirpsza, L.; Mustaev, A. Luminescent Probes for Ultrasensitive Detection of Nucleic Acids. Bioconjug. Chem. 2010, 21, 319-327. [CrossRef] [PubMed]

178. Juskowiak, B. Nucleic acid-based fluorescent probes and their analytical potential. Anal. Bioanal. Chem. 2011, 399, 3157-3176. [CrossRef] [PubMed]

179. Li, M.; Selvin, P.R. Luminescent Polyaminocarboxylate Chelates of Terbium and Europium: The Effect of Chelate Structure. J. Am. Chem. Soc. 1995, 117, 8132-8138. [CrossRef]

180. Soltani, N.; Manzoori, J.L.; Amjadi, M.; Lotfipour, F.; Jouyban, A. Development and validation of a spectrofluorimetric determination of calf thymus DNA using a terbium-danofloxacin probe. Pharm. Sci. 2016, 22, 2-8. [CrossRef]

181. Jakovljevic, I.; Petrovic, D.; Joksovic, L.; Lazarevic, I.; Jelikic-Stankov, M.; Djurdjevic, P. Complex formation equilibria between aluminum(III), gadolinium(III) and yttrium(III) ions and some fluoroquinolone ligands. Potentiometric and spectroscopic study. J. Coord. Chem. 2015, 68, 4272-4295. [CrossRef]

182. Su, Y.; Xu, Y.; Yang, L.; Yang, J.; Weng, S.; Yu, Z.; Wu, J. New, rapid fluorescence stain method for histologic sections using lanthanide complexes. Anal. Biochem. 2005, 347, 89-93. [CrossRef] 
183. Lin, J.; Zheng, Y.; Wang, Q.; Zeng, Z.; Zhang, C.C. Novel lanthanide pH fluorescent probes based on multiple emissions and its visible-light-sensitized feature. Anal. Chim. Acta 2014, 839, 51-58. [CrossRef]

184. Leyva, S.; Hernández, H. Synthesis of norfloxacin analogues catalyzed by Lewis and Brönsted acids: An alternative pathway. J. Fluor. Chem. 2010, 131, 982-988. [CrossRef]

185. Polishchuk, A.; Karaseva, É.; Korpela, T.; Karasev, V.E. New luminophor-activators based on (fluoro)quinolone antibacterials. J. Lumin. 2008, 128, 1753-1757. [CrossRef]

(C) 2020 by the authors. Licensee MDPI, Basel, Switzerland. This article is an open access article distributed under the terms and conditions of the Creative Commons Attribution (CC BY) license (http://creativecommons.org/licenses/by/4.0/). 